\title{
ARTICLE
}

\section{MONEY MATTERS: JUDICIAL MARKET INTERVENTIONS CREATING SUBSIDIES AND AWARDING FEES AND COSTS IN INDIVIDUAL AND AGGREGATE LITIGATION}

\author{
JUDITH RESNIK ${ }^{\dagger}$
}

\section{TABLE OF CONTENTS}

I. MONEY AND THE "ETIQUETTE" OF THE CIVIL JUSTICE SYSTEM ...................................................... 2120

II. ALTERNATIVE CONCEPTIONS OF CIVIL JUSTICE ........................2130

A. State Subsidies or Unaided Access .........................................2131

B. Ambivalence About Mandating Cross-Litigant Wealth Transfers................................................................2137

C. Laissez-Faire Lawyering or Regulated Advocacy: Shifting Judicial Roles ........................................................2140

D. The Resultant Tensions ........................................................2142

III. AGGREGATE LITIGATION: WHAT IT BRINGS AND BUYS........... 2144

A. Class Actions as State-Enabled Litigation .................................. 2144

B. MDLs as Regulatory Regimes.................................................2148

C. Inter-Litigant Equity..............................................................2152

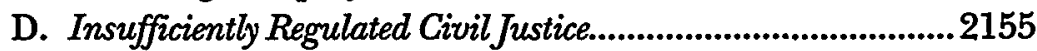

IV. TALKING ABOUT MONEY ...................................................2163

A. Judges as Purchasers of Services ............................................... 2163

B. Paying for Process ......................................................................2166

$\dagger$ All rights reserved. This essay was first presented at Mass Torts: A Symposium (sponsored by the David Berger Program on Complex Litigation and the University of Pennsylvania Law School in conjunction with the Advisory Committee of Civil Rules of the Judicial Conference of the United States, November 11-12, 1999). My analyses grow out of work on (and sometimes in) the civil litigation system that I have shared with Dennis Curtis, Owen Fiss, and Deborah Hensler. Thanks also to Ian Ayres, Patrick Higginbotham, Tony Kline, John Langbein, Henry Monaghan, Nancy Moore, David Shapiro, Elizabeth Warren, and Brian Wolfman for helpful insights, and to Steve Engel, Laura Fernandez, Matthew Kutcher, Sarah Russell, and Josh Tate, for research assistance both thoughtful and fun. 


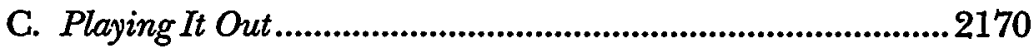

D. Revising Fee Law, Refocusing Civil Justice............................2172

1. Regulating Attorney-Client Relationships................... 2172

2. Reassessing Measures of Value, Regulating Advocacy, and Requiring Disclosures........................................2177

3. Judicial and Congressional Subsidies.........................2190

V. TRANSPARENT INDEPENDENCE.............................................2193

\section{MONEY AND THE "ETIQUETTE" OF THE GTIL JUSTICE SYSTEM}

The topic of this symposium is mass torts. My focus is on fees, costs, and subsidies. Given that my co-participants are judges, lawyers, and academics steeped in current practices (indeed creating them), I have no need to rehearse the arguments about the different methods used for paying lawyers or the insufficiency of current law. The law of attorneys' fees is the subject of dozens of law review articles, and both academic and popular literature evidence a shared sense that "something" needs to be done.

But I do need to explain why figuring out what to do is difficult. As I begin to discuss a) judicial intervention into the market for legal services; b) judicial allocation of lawyers' fees that turn judges into purchasers of legal services; $c$ ) the challenges of determining whether and how to subsidize which litigants; and d) the effects of such decision making on the judicial role, I am conscious that I am engaging in a breach of etiquette. I am talking about judges directing the flow of money in civil litigation. But the discourse of civil justice has tried to avoid that topic; the phrase-judges as market-makers-is not regularly deployed.

While the relationship between judges and money is not much discussed, that money itself abounds in many mass torts is, of course, a focus of attention. Because of the stunning amounts at issue, commentators call repeatedly for courts to permit only "reasonable" attorneys' fees and to increase monitoring of payments. Yet despite a good deal of such discussion, what constitutes a "reasonable" fee and how courts (or legislatures, for that matter) should regulate attorneys' fees and costs have not been elaborated in the many proposals about how to revise the processes of mass tort litigation. ${ }^{1}$

${ }^{1}$ The impressive and thorough Report on Mass Tort Litigation is illustrative. See ADVISORY COMM. ON GIII RULES \& WORKING GROUP ON MASS TORTS, REPORT ON MASS TORT LITIGATION (Feb. 15, 1999) [hereinafter REPORT ON MASS TORT 
Similarly, while hundreds of reported decisions address attorneys' fees, most of that case law is not tailored to mass torts, with its layers of lawyers, some of whom are individually retained plaintiffs' lawyers and do work solely for specific clients and others of whom are authorized to speak for the group, either as "class action" lawyers or as members of "plaintiffs' steering committees." Further, in the small but growing case law on fee awards specifically in mass torts, judges appear reluc-

LITIGATION]. Because the conference conveners were eager for speakers to engage with the Report, they provided us with references to the pages on which our respective topics appear. In the twenty or so mentions of money in the body and appendices of the Report, few details are provided about regulatory regimes for mass tort fees and expenses. See id. at 17-18 (discussing law firms' interest in aggregation because "intensive investment of time and expense ... could not be supported by litigation on behalf of only a few clients"); $i d$. at 18 (noting the possible reduction in plaintiffs' litigation costs and defense interests in increasing plaintiffs' costs); $i d$. at 21 ("[F] ee awards are one of the engines driving mass-tort litigation."); $i d$. at 30 (discussing "transaction costs"); $i d$. at 43-45 (discussing concerns about the impact of large fee awards); id. at 61-62 (describing the need for "[i]ncreased control over attorney fees"); id. app. C at 124 (citing David Shapiro's discussion of the need to monitor fees); id. app. F-5, at 2 (stating that in settlement classes, courts should review "whether any provisions for attorney fees are reasonable"); id. at app. F-7, at 4 (providing a statutory "all encompassing" model that would have courts "set fees for an attorney appointed to represent" mass tort plaintiffs "at a level that is reasonable in relation to the extent and quality of the work performed" and the financial risks borne); id. app. F-8(d), at 2 (that judgments for "reasonable" attorney fees could be "nothing"); $i d$. app. F-12, at 7 (discussing that expert counsel and other expert costs be taxed against petitioners); id. app. F-13, at 4 (providing the ABA Commission on Mass Torts Recommendation 10, that bench and bar "develop guidelines for determination of reasonable fees and expenses . . . address[ing] the reasonableness of fixed percentage contingent fees in situations where multiple clients are represented, where liability is not seriously in issue" or where "lead counsel or others perform a major portion of the representation").

As these references illustrate, the Working Group on Mass Torts considered the major extant suggestions about mass torts, not all of which themselves address fees or costs. See, e.g., AMERICAN LAW INST,, COMPLEX LITIGATION: STATUTORY RECOMMENDATIONS AND ANALYSIS WITH REPORTERS' STUDY (1994) [hereinafter ALr, COMPLEX LITIGATION] (proposing additional means of aggregation but not discussing the economic incentives thus created). In contrast, a few proposals are devoted to the question of fees. See Report of the Third Circuit Task Force: Court Awarded Attorney Fees, 108 F.R.D. 237 (1985).

${ }^{2}$ Those relationships are examined in Judith Resnik, Dennis E. Curtis \& Deborah R. Hensler, Individuals Within the Aggregate: Relationships, Representation, and Fees, 71 N.Y.U. L. REV. 296 (1996) [hereinafter Resnik, Curtis \& Hensler, Individuals Within the Aggregate]; Dennis E. Curtis \& Judith Resnik, Contingengy Fees in Mass Torts: Access, Risk, and the Provision of Legal Services When Layers of Lawyers Work for Individuals and Collectives of Clients, 47 DEPAUL L. REV. 425 (1998) [hereinafter Curtis \& Resnik, Contingency Fees]; and in Marc Galanter, Anyone Can Fall Down a Manhole: The Contingency Fee and Its Discontents, 47 DEPAUL L. REV. 457 (1998). In contrast, David Shapiro has argued that, given significant distinctions between mass and ordinary tort litigation, a conception of the class as an entity-rather than as individuals aggregated together-is preferable. See David L. Shapiro, Class Actions: The Class As Party and Client, 73 NOTRE DAME L. REv. 913 (1998). 
tant to delve too deeply into the relationships among the various lawyers and the way they allocate and spend the moneys paid to them. Despite a legal and popular press filled with stories about large sums paid, collusion, ${ }^{4}$ the possibility of kickbacks or payoffs, and entrepreneurial excesses, judges-in general-do little to superintend how lawyers divide money among themselves, which lawyers are paid for what services, or what "side settlements" (made either between lawyers or between defendants and subsets of litigants) are permissible. ${ }^{5}$

Judges are not the only ones reluctant to confront these issues. While members of Congress have been complaining about class action "abuses" and have translated some of these concerns into law, the statutes enacted or proposed provide only general guidelines, leaving much to judicial discretion. ${ }^{6}$ Further, those statutes and bills do not

${ }^{3}$ Press coverage of compensation of attorneys has been extensive, much of it focused on overpayment. See, e.g., Matthew Scully, Contingency Fees: Another Name for Champerty, WAII ST. J., Nov. 10, 1997 at A23; Ann Davis, Tobacco-Industry Largess Puts Plaintiffs' Lawyers in Fat City, WALI ST. J., Oct. 8, 1988, at B1.

4 See, e.g., Samuel Issacharoff, Class Action Conflicts, 30 U.C. DAvIs L. REv. 805 (1997); Bruce L. Hay, The Theory of Fee Regulation in Class Action Settlements, 46 AM. U. L. REv. 1429 (1997); Roger C. Cramton, Individualized Justice, Mass Torts, and "Settlement Class Actions": An Introduction, 80 CORNELI L. REV. 811 (1995); Susan P. Koniak, Feasting While the Widow Weeps: Georgine v. Amchem Products, Inc., 80 CORNELI L. REV. 1045 (1995).

${ }^{5}$ The circuit law is somewhat mixed. Obligations for some judicial supervision are found in In re "Agent Orange" Prod. Liab. Litig., 818 F.2d 216, 226 (2d Cir. 1987) (requiring disclosure of such agreements and prohibiting certain forms). See also S.D.N.Y. \& E.D.N.Y. LOCAL R. 23.1 (requiring a public hearing on fee applications with notice stating the amounts of fees requested and the existence of fee sharing agreements).

But, as the Sixth Gircuit explained when distinguishing that rule, all the Second Circuit required was disclosure of fee arrangements among lawyers to the court, not to the other lawyers in the case. See Bowling v. Pfizer, Inc., 102 F.3d 777, 781 (6th Cir. 1996) (concluding that "[h]ow special counsel and class counsel ultimately divide" fees "appears to be irrelevant"); see also Longden v. Sunderman, 979 F.2d 1095, 1100-01 (5th Gir. 1992) (awarding lump sum for private distribution among attorneys); In re Copley Pharm., Inc. "Albuterol" Prods. Liab. Litig., 50 F. Supp. 2d 1141, 1148 (D. Wy. 1999) (asking counsel to work out a fee-sharing agreement, described to be a private matter to be handled among class counsel" (citation omitted)); Duhaime v. John Hancock Mut. Life Ins. Co., 183 F.3d 1, 7 (1st Cir. 1999) (rejecting court superintendence of side-settlements to claimants).

${ }^{6}$ See Private Securities Litigation Reform Act of 1995 [hereinafter PSLRA], Pub. L. No. 104-67, 109 Stat. 737, codified at 15 U.S.C. $\$ 77 z-1$ (a)(6) (Supp. IV 1998), as amended by the Securities Litigation Uniform Standards Act of 1998, Pub. L. 105-353, 112 Stat. 3227, codified at 15 U.S.C. $\$ \$ 77,78$ (restricting the "[t]otal attorneys' fees and expenses awarded by the court to counsel for the plaintiff class" by prohibiting payment beyond "a reasonable percentage of the amount of any damages and prejudgment interest actually paid to the class"). Criticism can be found in James D. Cox, Making Securities Fraud Class Actions Virtuous, 39 ARIZ. L. REv. 497 (1997).

The innovation of the securities fee statute is to limit judicial discretion by requir- 
directly address cases in which many co-venturing and/or conflicting lawyers are before courts on behalf of a collective of claimants. While a few non-governmental organizations, such as the Manhattan Institute, have argued for greater regulation of contingent fees ${ }^{8}$ and some academics (myself included) have made proposals to alter either the means of paying fees or the reasons for paying fees, ${ }^{9}$ the institutional voices of lawyers and judges (the American Law Institute, the American Bar Association, and court-based rule drafting committees) have

ing that fees are a percentage of moneys actually received by class members, as contrasted to a percentage of a fund established. Because some class members may never claim their recoveries, the statute's link of fees to actual receipt of recoveries encourages attorneys to seek out and assist litigants in collecting recoveries. The statute's reliance on a "reasonable" percentage, is not, however, innovative. The Act also leaves to judicial discretion the means of fee calculation, which could be either by the lodestar or the percentage of the fund basis. Congress also created a presumption in favor of large stake holders being permitted to select (subject to court approval) attorneys to represent the class. PSLRA, 15 U.S.C. § 77z-l(a)(3)(B)(v). See also the "Y2K Act," $\S 15$, Pub. L. No. 106-37, 113 Stat. 185, 201 (1999), to be codified at 15 U.S.C. $\S 6614$ which imposes an additional notice requirement on such class actions, that members of the class learn about "the fee arrangements with class counsel, including the hourly fee being charged, or, if it is a contingency fee, the percentage of the final award which will be paid, including an estimate of the total amount that would be paid if the requested damages were to be granted"; and the pending Class Action Fairness Act of 1999 , S. 353, 106th Cong. (1999), explained by Senator Grassley as aimed at ending "class action lawsuit abuses where the plaintiffs receive very little and their lawyers receive a whole lot," by requiring notification of state attorney generals of proposed settlements and by limiting fees and expenses to a "reasonable percentage" of actual damages, future financial benefits, and costs actually incurred by the defendants. 145 CONG. REC. S1166-67 (daily ed. Feb. 3, 1999). That bill would also expand federal diversity jurisdiction over class actions. On Sept. 23, 1999, the House passed a related class action bill, The Interstate Class Action Jurisdiction Act of 1999, H.R. 1875, 106th Cong. (1999), that provides for removal of "interstate" classes to the federal courts but does not address attorney fees. See 145 CONG. REC. H8568-602 (1999).

${ }^{7}$ Some multi-lawyer cases do fall under statutory regulation. See, e.g., PSLRA, 15 U.S.C. $\$ 77 z-1(a)(3)(B)$ (v) (requiring judicial approval of lead counsel). In some instances, courts have selected more than one firm to work together. See, e.g., In re Party City Sec. Litig., 189 F.R.D. 91, 114, 116 (D.N.J. 1999) (stressing the "independent evaluation" to be undertaken by the court, the requirement that lead plaintiff select counsel after "hard-bargaining," and approving the appointment of two law firms as colead counsel).

${ }^{8}$ See LESTER BRICKMAN, Michael J. HOROWTIZ \& JEFFrEy O'CONNELL, RETHINKING CONTINGENCY FEES (Manhattan Institute 1994).

'See, e.g., John C. Coffee, Jr., Class Wars: The Dilemma of the Mass Tort Class Action, 95 Colum L. REv. 1343 (1995) [hereinafter Coffee, Class Wars]; Jonathan R. Macey \& Geoffrey P. Miller, The Plaintiffs' Attorney's Role in Class Action and Derivative Litigation: Economic Analysis and Recommendations for Reform, 58 U. CHI. L. REV. 1 (1991) [hereinafter Macey \& Miller, The Plaintiffs' Attomey's Role]; John C. Coffee, Jr., The Regulation of Entrepreneurial Litigation: Balancing Faimess and Efficiency in the Large Class Action, $54 \mathrm{U}$. G.II. L. REv. 877 (1987); Resnik, Curtis \& Hensler, Individuals Within the Aggregate, supra note 2. 
not yet worked out details about how to handle and distribute the fees and expenses of mass tort litigation.

Hence, I need to explain why regulation that seems so obviously needed has not been much developed. To understand the problem posed by money in mass torts requires exploring yet larger topics: the role of the civil justice system in the United States and the work of judges within it. Aggregate litigation-including but not limited to class actions-is a site of conflict about the purposes of the civil justice system because aggregation can serve as a means of reallocating resources among litigants. ${ }^{10}$ By authorizing or presiding over aggregate litigation, judges become allocators and purchasers of legal services. In order to decide whether and how to allocate legal services (what to buy, whether to subsidize, and when to transfer costs from one participant to another), one needs to know what one wants to achieve. Lacking a theory of the goals of civil justice, or more accurately, living within a system replete with conflicting and changing goals, judges and legislators are understandably unclear about what to do.

Thus, guidance requires excavating the assumptions about the role of government interventions that affect the economic capacity of litigants to seek relief from the civil justice system and about the purposes of the civil justice system itself. To do so, in turn, demands identifying the background premises (formed in the context of individual litigation) about the respective roles of litigants, lawyers, and judges in the civil justice system.

Below, in Part II, I provide a brief history of subsidies for civil litigants in individual litigation. That review identifies what I term unaided access as a basic tenet of the civil justice system, committed to litigant self-sufficiency rather than judicial assistance for those seeking to come into court. On the rare occasion when judges rule that state subsidies must be provided, opinions provide remarkably thin discussion of why intervention is required in the category of cases selected for funding but not required in other instances when poor litigants seek court assistance to make their claims. I turn then to an interrelated and second premise, laissez-faire lawyering, which requires me to provide less by way of elaboration because it refers to the familiar and pervasive presumption that attorneys are free within an adversary sys-

${ }^{10}$ See, e.g., George L. Priest, Procedural Versus Substantive Controls of Mass Tort Class Actions, 26 J. LEGAL STUD. 521 (1997). He argues that such actions are "massive tool[s] of redistribution," $i d$. at 522, and objects to class actions' ability to generate "outcomes that depart very substantially from the substantive ambitions of tort law," $i d$. at 526, which he defines to be efficiency, equity, and finality, $i d$. at 541-43. 
tem to manage their relationships with clients, opponents, and courts and to pursue their goals with minimal regulation.

But such assumptions are neither static nor uncontested. For some, the civil justice system is predicated on individual entrepreneurial effort. For others, because civil justice is a special service that offers a unique outcome-a court's power of judgment-government should ease access (in at least some contexts) either by government subsidies or by requiring economic transfers among litigants. Further, while unfettered lawyering still has its proponents, over the past several decades judges have adopted a series of regulatory measures, aimed at curbing perceived excesses of adversarialism. Hence, unaided access and laissez-faire lawyering are in tension with state-enabled litigation and regulated advocacy.

Not only are there conflicting and changing impulses within the civil justice system towards lawyers and money. Conflict and change also mark the modes of processing cases within the civil justice system, as is explicated in Part III. The paradigm of individualized adjudication has been displaced in certain arenas with a presumption in favor of aggregate processing, whether by class action or by other means, such as bankruptcy, multi-district litigation, consolidation, informal collective devices, or agency-based processing. The adjudicatory model is itself yielding to processes aimed at settling, rather than trying, cases. And judges, formerly identified as solo actors rendering judgments, now have a wider array of roles (manager, settler, conciliator), ${ }^{11}$ assisted by a staff of adjuncts, offering a range of dispute resolution services.

Within the phrase "mass torts" lies evidence of both the causes and effects of changes in civil justice processing. Judicial superintendence over torts ranging from mass accidents to defective products has provided insight that similarly situated litigants are not always treated alike, that despite aspirations for inter-litigant equity, the civil justice system has had little means of implementing that aspiration. Moreover, as aggregate mass tort processing occurs through legislative devices such as the multi-district litigation statute, judges intervene in

11 See Judith Resnik, Trial as Error, Jurisdiction as Injury: Transforming the Meaning of Article III, 113 HARV. L. REv. 924 (2000) [hereinafter Resnik, Transforming the Meaning of Article II]; Judith Resnik, Changing Practices, Changing Rules: Judicial and Congressional Rulemaking on Civil Juries, Civil Justice, and Civil Judging 49 ALA. L. REV. 133 (1997) [hereinafter Resnik, Changing Practices, Changing Rules]; Judith Resnik, Managerial Judges, 96 HARV. L. REV. 374 (1982) [hereinafter Resnik, Managerial Judges]. For discussion of the distinction between the judicial role evolutions about which I am concerned and the one I suggest here, see infra note 127. 
attorney-client relationships by appointing lawyers to speak on behalf of individuals with whom they have not contracted. Injuries allegedly suffered by large numbers of persons also prompt a large volume of cases-evidence of what I term civil docket excess. Mass torts thus make attractive both the aggregate processing of and the settlement of disputes.

Yet that very combination-mass torts, aggregation, and settlement-offers new strategic opportunities for both plaintiffs' and defendants' lawyers to pool resources, to shop for claimants or opponents, to amass warehouses of clients (often with substantial diversity among claimants) and to develop repeat-player relationships with adversaries, all of which enhances the appeal (if not the value) of closure for the many participants, including litigants, lawyers, judges, insurance companies, and others. Aggregation not only can lower the price of entry to the civil justice system, it also serves as a means of changing the packet of services the civil justice system provides. Aggregation thus creates new incentives for use of the system.

The alteration in opportunities and the strategic interactions made available have attracted the attention of lawyers, who have reorganized their practices, and of commentators and judges, who have become concerned that the civil justice system itself looks malleable, shielding if not enabling misuse of its potential. These problems reached the United States Supreme Court, which, in two recent opinions on mass settlements in asbestos litigations, demanded that judges ensure the legitimacy of the civil justice system by structuring and supervising relationships among litigants and lawyers to improve the information given to judges who are asked to transform parties' agreements into consent judgments. ${ }^{12}$ The Court imposed these new obligations first by reading the federal procedural rule permitting class actions and then by linking its interpretation to constitutional concerns about representative litigation. ${ }^{13}$ Yet, consistent with the old civil justice etiquette, the Court did so with little discussion of fees.

${ }^{12}$ See Ortiz v. Fibreboard Corp., 119 S. Ct. 2295 (1999); Amchem Prods., Inc. v. Windsor, 521 U.S. 591 (1997).

${ }_{15}$ In Amchem, the Court relied on rule interpretation, see 52I U.S. at 619-29, while the Ortiz Court tied its discussion of aspects of the class action rule to the "due process 'principle of general application in Anglo-American jurisprudence that one is not bound by a judgment in personam in a litigation in which he is not designated a party or to which he has not been made a party by service of process," $119 \mathrm{~S}$. Ct. at 2314-15 (quoting Hansbury v. Lee, 311 U.S. 32 (1940)). The Ortiz Court then discussed the "inherent tension between representative suits and the day-in-court ideal ... [which is] magnified if applied to damage claims gathered in a mandatory class." Id. at 2315. 
My argument, elaborated in Part $I V$, is that such regulatory efforts require that attention be paid to the distribution of funds among the many participants, unequal in their economic wherewithal, their access to information, and their participatory abilities. In other words, to implement the Supreme Court's mandate to judges settling mass torts, judges will have to pay for process, by funding subclass representatives, objectors, independent evaluators, or court employees to generate information and to organize the claimants effected in a manner that serves the civil justice system goals of resolving disputes equitably. To ensure the integrity of their own efforts, judges will have to breach the old civil justice etiquette of minimal inquiry about financial arrangements among lawyers. Judges can no longer ignore the economic implications of their rulings. Judges will have to learn which lawyers are paid what moneys for services rendered, about the side settlements negotiated among the many participants, and about the quality of services delivered.

In short, aggregate mass tort settlements (and their adjudications) demand of judges yet another new role. Aggregation and the failure of formal representative structures require judges, already moving away from a distanced stance, to leave behind not only their laissezfaire attitudes toward lawyering but also their prior posture of avoiding intervention to alter the economic incentives of lawyers. Regulating lawyering in mass tort aggregates entails decisions about what activities of lawyers to fund through ordering fee payments. The Supreme Court has implicitly instructed judges to finance one line of work by requiring restructuring of the configurations presented when parties propose settlements. To test such settlements to ensure both equitable distributions and adequate amounts of funds provided in settlement, judges have to know more than what the parties provide. Therefore, money can and should be spent in pursuit of societal goals different from those heretofore assumed to be implicit in civil ("private") justice. The growing dominance of aggregate processing and settlement demonstrates that the background assumptions of laissezfaire lawyering, unaided access, and unpoliced inter-litigant equity are being superseded by other goals-specifically, that civil justice provide a means of public norm enforcement and that it increase its ability to make dispositions and to make them uniformly among similarly situated litigants through regulation of lawyers and through constraints on litigants' options.

How much of a change is required? In the context of aggregation, judges have long claimed for themselves another role, that of fi- 
duciary for absentee claimants. ${ }^{14}$ Moreover, in that capacity, judges have awarded fees to attorneys either pursuant to the equitable "common fund" doctrine or based on congressional mandates to shift fees from loser to winner. Such aggregates have been assumed to be composed of claimants, indistinguishable from each other and represented by a single set of lawyers. In contrast, the relatively recent innovation of mass tort aggregates include an unruly collective of lawyers, fighting among themselves for recognition as the representatives of the interests of claimants who are themselves a diverse lot.

Yet even when acting as fiduciaries, judges sought to avoid imposition of value-laden assessments of the utility of forms of litigation in the context of common-fund and fee-shifting cases. Judges relied on measures of value that insulated them, somewhat, from analyzing the desirability of the pursuit of certain claims. During much of the past century, judges measured the value of lawyers' work in common-fund cases by reference to the economic benefit conferred on clients, paying a "percentage of the fund." That measure has been assumed to mimic what clients (were they directly deciding) would value; ${ }^{16}$ paying a percentage of a recovery also was familiar, given contingency fee contracts. During the second half of the twentieth century, as judges also become involved in awarding fees under fee-shifting statutes, they again sought refuge in market practices by relying on attorney customs of billing hourly fees at a given rate (the "lodestar").

The many opinions about how to set fees and what to pay for in such cases demonstrate that judges were not completely protected from making value judgments, such as whether to expand the common fund concept to permit awards in instances when benefits were conferred even in the absence of a specific fund, how to value funds, when to pay awards, whether to permit billing by multiple lawyers within a firm, and what rates to set. Further, through fee awards, markets for certain kinds of litigation grew; through awards for set-

${ }^{14}$ This proposition is often stated. See, e.g., Montgomery v. Aetna Plywood, Inc., No. 95-3193, 1999 WL 172313 (N.D. Ill. Mar. 18, 1999), vacated in part on other grounds, 1999 WL 299898 (N.D. Ill. May 3, 1999); Hallett v. Li \& Fung, Ltd., No. 95 Civ. 8917, 1998 WL 698354 (S.D.N.Y. Oct. 6, 1998).

${ }^{15}$ In common-fund cases, that benefit is typically measured by providing as attorneys' fees a "percentage of the fund bestowed on the class." Blum v. Stenson, 465 U.S. 886, 900 n.16 (1984). This notion developed from the equity "common fund" doctrine. See, e.g., Trustees v. Greenough, 105 U.S. 527 (1881); Sprague v. Ticonic Nat'I Bank, 307 U.S. 161 (1939).

${ }^{16}$ See, e.g., John F. Grady, Reasonable Fees: A Suggested Value-Based Analysis for Judges, 184 F.R.D. 131, 131-32 (reprinting a speech given in October of 1998, and arguing for assessment not predicated solely on a fund's economic value). 
tlement as well as for victories at trial, incentives to conclude cases by a variety of means were put into place. But judges attempted to maintain role clarity by explaining their actions when awarding fees by reference to the external norms of the marketplace for legal services. Indeed, it is commonplace in the literature on attorneys' fees to cite Richard Posner for the proposition that judges, when setting fees, should mimic the market. ${ }^{17}$

My argument is that, in mass torts, judges are the market. Judges now have the power of payment, serving more like clients and consumers, altering demand and supply by shaping aggregates and settlements, by valuing certain forms of lawyering, and by directing capital not only to lawyers but to a host of subsidiary service providers, including banks, accountants, and staff of claims facilities. Judicial allocation decisions thus shape the incentives of lawyers evaluating what new claims to pursue. Moreover, judicial appointments and fee awards affect the capacity of specific lawyers to gain dominant positions within the marketplace. And, some judges enter into transactions with the same lawyers time and again.

Hence, it becomes irresponsible not to talk openly about how judges should spend money in pursuit of social goals achieved through litigation. To craft useful regulation about money in mass torts requires acknowledgment that aggregation destroys the laissezfaire market paradigm of civil litigation and with it the ability of judges to find safe harbor in the handiwork of outsiders fashioning markets of legal services. Instead, judges need to recognize their role in mass tort aggregate settlements as lawmakers structuring markets in legal services. Judges need not act alone; legislation has a special place when money matters are at issue in civil litigation, and govern-

${ }^{17}$ See, e.g., Peter H. Huang, A New Options Theory for Risk Multipliers of Attomey's Fees in Federal Civil Rights Litigation, 73 N.Y.U. L. REv. 1943, 1967 (1998). Judge Posner has authored a number of opinions invoking this proposition. See, e.g., Gaskill v. Gordon, 160 F.3d 361, 363 (7th Cir. 1998) ("When a fee is set by a court rather than by contract, the object is to set it at a level that will approximate what the market would set. ... The judge, in other words, is trying to mimic the market in legal services."); Cooper v. Casey, 97 F.3d 914, 920 (7th Cir. 1996) ("[T] he reasonable fee is capped at the prevailing market rate for lawyers engaged in the type of litigation in which the fee is being sought."); In re Continental Ill. Sec. Litig., 985 F.2d 867, 868 (7th Cir. 1993) ("These contracts would provide a market estimate of the value of the class lawyers' service to the class, in accordance with the principle that a judge in setting a fee award should be trying to give the lawyers what they would have got in a voluntary transaction in the market for legal services."); Henry v. Webermeier, 738 F.2d 188, 193 (7th Cir. 1984) ("Our problem with the court's approach is that it lacked a starting point. The court did not say, "The market rate for each of these lawyers is $\$$ — and I will adjust it upward or downward by so much.'"). 
ment subsidies mandated by Congress may well be an appropriate route to take. But as long as aggregation continues to be used in mass torts, judges have a significant role to play in that market. Recognizing and understanding the import of that role-shift helps to bring attention to another problem, overshadowed now by the focus on lawyer excesses, about the import of such a role-shift for judges. At issue is how to create rules for judges to enable them to function as independent actors whose decision making is sufficiently transparent to the public so as to sustain its legitimacy.

Now to the elaboration.

\section{Alternattve CONCEPTIONS OF CIVIL JUSTICE}

Let me begin with the background understanding-what I have termed the "etiquette" of the civil justice system towards fees, costs, and subsidies. Money is not only a hard subject in aggregate litigation; it is a difficult, indeed a haunting, problem for the civil litigation system in general. The challenge stems from conflicting sets of bedrock premises.

One set of propositions takes litigants as they come, neither offering anything by way of assistance or subsidy nor regulating the relationship between client and attorney. Civil litigants are free to find lawyers (or not) and then to make their way through the adversarial processes as best they can, on their own. These premises are deeply embedded within United States culture, generated from the mix of capitalism, individualism, attorney entrepreneuralism, ambivalence about regulation, readings of constitutional text, history and happenstance. Laissez-faire lawyering and unaided access are my shorthand.

But of course, such an approach comes at a high cost, which is why a second, and conflicting, set of propositions have emerged, requiring subsidies and intervention in attorney-client relationships. The impulse to subsidize emerges from an understanding that: (a) the adversary system is not at its best when opposing disputants are illmatched in terms of resources; (b) the justice system is sometimes the only route available to achieve a given end and relies on litigant capacity to legitimate the rulings made; (c) lawyers-the principal gatekeepers and translators of civil justice-are sometimes irresponsible towards clients or courts, providing bad or overly-expensive representation to clients, consuming too much of courts' resources, and thereby imposing on others in the litigation queue; (d) single-plaintiff cases are an inefficient means of processing large numbers of similar claims; and (e) equitable treatment across similar kinds of litigants is 
desirable. Hence, laissez-faire lawyering and unaided access clash with impulses to constrain lawyers and to provide assistance to some litigants.

\section{A. State Subsidies or Unaided Access}

The conflict became particularly vivid during the later half of the twentieth century. On the criminal side, the lack of equilibrium between government and individual defendants proved insupportable, generating concern about the integrity of criminal judgments. The United States Constitution was therefore reread to require equipagecounsel (in Gideon ${ }^{18}$ ), investigative and expert capacity (in $A k e^{19}$ ), disclosure (in $B r a d y^{20}$ ), subsidies for appeal when offered by states (in Douglas $^{21}$ ) -all in response to a shared sense of the illegitimacy of outcomes borne from deeply unequal resources. ${ }^{22}$

The civil justice system has been more reluctant to adopt a parallel attitude towards litigants within it. Characterized as focusing on "private" interactions among disputants, civil justice imagines a certain fungibility of litigants that is foreign to the criminal justice system, in which the state is always the prosecutor. ${ }^{23}$ If the rules of civil procedure sometimes tilt towards plaintiffs (for example, when evaluating complaints for dismissal) or towards defendants (for example, when imposing burdens of proof), neutrality results from the assumption that plaintiffs and defendants are themselves revolving sets of players, interchangeable from one case to another. The brunt of whatever as-

${ }^{18}$ Gideon v. Wainwright, 372 U.S. 335 (1963).

${ }^{19}$ Ake v. Oklahoma, 470 U.S. 68 (1985).

${ }^{20}$ Brady v. Maryland, 373 U.S. 83 (1963).

${ }^{21}$ Douglas v. California, 372 U.S. 353 (1963); see also Griffin v. Illinois, 351 U.S. 12 (1956) (requiring transcripts on appeal for indigent criminal defendants); Williams v. Oklahoma City, 395 U.S. 458 (1969) (applying subsidized transcript rule to a misdemeanant facing imprisonment); Mayer v. Chicago, 404 U.S. 189 (1971) (requiring the state to provide an appellate transcript for an appeal of a misdemeanant conviction involving no imprisonment); Burns v. Ohio, 360 U.S. 252 (1959) (requiring the waiver of a filing fee when indigents seek state supreme court review of a criminal conviction).

${ }_{22}$ While these cases represent an alteration of the unassisted access principle, they do not address laissez-faire lawyering. That approach-that a client is pretty much stuck with decisions of his/her own lawyer-is robust within criminal law, as exemplified by the extremely limited circumstances under which convictions are vacated on the grounds of ineffective assistance of counsel. See Strickland v. Washington, 466 U.S. 668 (1984); Williams v. Head, 185 F.3d 1223 (11th Cir. 1999); note 58 infra.

${ }^{23}$ For discussion of the effect of that knowledge on criminal rulemaking and the differing approaches of civil justice, see Judith Resnik, The Domain of the Courts, 137 U. PA. L. REV. 2219 (1989). 
sistance any rule affords to one side of a civil suit will over time be felt by all, thereby providing reassurance about legitimacy.

But even the civil justice system has its moments when pricing access to its processes makes the inequality of resources between litigants too much to bear. The veil of ignorance that assumes any person could be either plaintiff or defendant is pierced (if not lifted). Subsidies and wealth transfers within litigations-such as the waiver of filing fees, the provision of lawyers, the payment for development of expert information, or shifting costs among litigants-are provided. The means vary-from public funding, taxing lawyers by requiring contributions from attorney trust accounts, ${ }^{24}$ to requiring that costs be reallocated within a specific litigation. ${ }^{25}$ These principles emanate

${ }^{24}$ Questions about the constitutionality of this practice were raised but not answered in Phillips v. Washington Legal Foundation, 524 U.S. 156 (1998) (holding that, under Texas law, interest on lawyers' client trust accounts- "IOLTA"-is the "property" of clients for purposes of the Takings Clause and remanding for consideration of whether such funds had been "taken" by the State, whether "just compensation" was due, and whether state requirements that such funds be given to support legal services to the poor were lawful). On remand, the district court concluded that no taking had occurred. See Washington Legal Found. v. Texas Equal Access to Justice Found., 86 F. Supp. 2d 624, 646-47 (W.D. Tex. 2000).

${ }_{25}$ The Civil Rights Attorney's Fees Awards Act of 1976, codified at 42 U.S.C. $\$ 1988$ (1994), is a frequently cited example of a one-way fee shift. Lawyers for prevailing plaintiffs but not defendants receive payment from their losing adversaries. To be eligible for such shifts, the plaintiff must "prevail," defined as being able to "point to a resolution of the dispute which changes the legal relationship between itself and the defendant." Texas State Teachers Ass'n v. Garland Indep. Sch. Dist., 489 U.S. 782, 792 (1989). Fees are not reimbursed for work done in pursuit of claims or theories that did not succeed. See Hensley v. Eckerhart, 461 U.S. 424 (1983). The degree to which the recovery is "nominal" may affect the assessment of the propriety and amount of fees awarded. See Farrar v. Hobby, 506 U.S. 103 (1992).

Determining when a litigant has prevailed remains a subject of litigation. The Court in Farrar held that a plaintiff prevails "when actual relief on the merits ... materially alters the legal relationship between the parties by modifying the defendant's behavior in a way that directly benefits the plaintiff." Id. at 111-12. Lower courts have debated the meaning of that language. The Fourth Circuit has concluded that the "fact that a lawsuit may operate as a catalyst for post-litigation changes in a defendant's conduct cannot suffice to establish plaintiff as a prevailing party." See S-1 \& S-2 v. State Bd. of Educ., 21 F.3d 49, 51 (4th Cir. 1994) (en banc). Other circuits have concluded that Farrar permits recovery on the basis of a "catalytic" effect. See, e.g., Marbley v. Bane, 57 F.3d 224, 233-34 (2d Cir. 1995); Kilgour v. Gity of Pasadena, 53 F.3d 1007, 1010 (9th Cir. 1995); Zinn v. Shalala, 35 F.3d 273 (7th Cir. 1994); Baumgartner v. Harrisburg Hous. Auth., 21 F.3d 541, 550 (3d Cir. 1994); Little Rock Sch. Dist. v. Pulaski County Special Sch. Dist., \# 1, 17 F.3d 260 (8th Cir. 1994). In a case in which the trial court had not determined fees, the Supreme Court noted but declined to resolve the split. See Friends of the Earth, Inc. v. Laidlaw Envtl. Servs. (TOC), Inc., 120 S. Ct. 693, 711 (2000).

A prevailing defendant is entitled to fees only upon showing that plaintiff's suit was 
from constitutional interpretation, statutory law, and procedural rulemaking.

A first example comes from the 1971 decision of Boddie v. Connecticut. ${ }^{26}$ The Supreme Court held that at least in the case of divorce, the state had (as a matter of equal protection, due process, or some illdefined mixture of the two) to subsidize a litigant too poor to pay state-imposed filing fees. ${ }^{27}$ For some, Boddie's rule suggested that pricing entry to courts (even in terms of imposing below-cost filing fees) was similarly unfair and unconstitutional in other contexts.

But the Court thereafter reasserted what I have termed the "etiquette" of the civil justice system-that the system takes litigants as it finds them, and if litigants cannot make their own way into the system, that problem is not one that the Constitution solves. Hence, the Court refused (in Ortwein v. Schwab $b^{28}$ ) to require a waiver of filing fees when welfare recipients sought judicial review of a reduction in benefits, and the Court refused state-subsidized access (in Kras $v$. United States $^{29}$ ) to a proposed bankruptcy petitioner alleging inability to pay the filing fee.

Subsidizing filing fees for divorces is not the only example of constitutional alteration of the unaided access premise. The relatively few other instances stem from cases in which the state litigates against individuals and the issues at stake are-in substantive due process terms- "fundamental." Thus, in quasi-criminal proceedings (such as civil commitment processes in which loss of physical liberty is possible), counsel may be provided for an impoverished litigant from pub-

"frivolous, unreasonable, or otherwise without foundation." Christiansburg Garment Co. v. EEOC, 434 U.S. 412, 421 (1978); see also Bercovitch v. Baldwin Sch., Inc., 191 F.3d 8 (1st Cir. 1999) (interpreting the Americans with Disabilities Act fee-shifting requirements to be a one-way, pro-plaintiff, shift).

Other statutory fee-shifting statutes have been construed to create a two-way shift. See Fogerty v. Fantasy, Inc., 510 U.S. 517, 534 (1994) (interpreting the fee-shifting provisions of the Copyright Act to treat "[p]revailing plaintiffs and prevailing defendants ... alike" in awarding attorneys' fees). Taxation of costs provides another example of cost shifting. See FED. R. GTV. P. 54(d), discussed infra at note 47 and accompanying text.

${ }^{26} 401$ U.S. 371 (1971).

${ }^{27} I d$ at 383 (" [A] State may not... pre-empt the right to dissolve [a marriage] without affording all citizens access to the means it has prescribed for doing so.").

${ }_{23}^{23} 410$ U.S. 656, 659-60 (1973) (per curiam) (holding that the $\$ 25$ access fee did not impinge on a "fundamental interest" and that, under the applicable equal protection analysis, a state's need for revenue was a "rational" justification for the fee).

${ }^{29} 409$ U.S. 434 (1973). See generally Frank I. Michelman, The Supreme Court and Litigation Access Fees: The Right To Protect One's Rights, 1973 DUKE L.J. 1153. 
lic funds. ${ }^{30}$ Similarly, prisoners cannot be deprived of all access to courts, although the means required to be made available has recently been narrowed. ${ }^{31}$

One other litigation posture-cases in which the state attempts to create or to terminate parental rights-has also been recognized by federal courts as requiring, as a matter of constitutional law, litigation subsidies. $^{32}$ In Lassiter v. Department of Social Services, ${ }^{33}$ the Supreme Court concluded that, by virtue of the Due Process Clause, persons facing loss of the status of parent could, but only under limited circumstances, be subsidized through the provision of counsel. ${ }^{34}$ Em-

${ }^{30}$ See Vitek v. Jones, 445 U.S. $480,481-82$ (1980) (finding, by four justices, a right to counsel for an indigent person who was transferred to a civil commitment facility). Justice Powell concurred that assistance was required but might be provided by appropriately trained non-lawyers. Id. at 500; see also In re Gault, 387 U.S. 1, 41 (1967) (providing counsel for juveniles detained as delinquent). Right to counsel for civil commitment is a feature of most states' commitment laws. See, e.g., CONN. GEN. STAT. ANN. $\S 17 a-498$ (West 1999); KAN. STAT. ANN. § 59-2959 (1998); MASS. GEN. LAWS ANN. ch. $123, \S 5$ (West 1999); MTCH. COMP. LAWS ANN. $\$ 330.1454$ (West 1999).

${ }^{11}$ See Bounds v. Smith, 430 U.S. 817, 828 (1977) (holding that states had to assist prisoners seeking access to courts through the provision of law libraries or of attorneys); see also Lewis v. Casey, 518 U.S. 343, 351-54 (1996) (narrowing the guarantees of Bounds by requiring prisoners to show both that the lack of resources, such as a law library, caused them to be unable to seek judicial relief and that state restrictions on such resources were not justified).

${ }^{32}$ The limited imposition of constitutional requirements of subsidies is, of course, related to rulings that rejected the concept of poverty as a category upon which to base equal protection challenges. See San Antonio Indep. Sch. Dist. v. Rodriguez, 411 U.S. 1 (1973). And just as some states have responded differently than the federal courts in the context of school-financing litigation, some state courts have also departed from federal constitutional models and interpreted their own constitutions as requiring more litigation subsidies than does the federal constitution. See, e.g., In re K.L.J., 813 P.2d 276, 282 n.6 (Alaska 1991) (rejecting the federal constitutional "case-by-case approach" in favor of an interpretation of the Alaska Constitution's due process clause that requires counsel for all indigents when termination of parental rights is sought); Choiniere v. Brooks, 660 A.2d 289, 289-90 (Vt. 1995) (same).

ss 452 U.S. 18 (1981).

34 The crabbed and cumbersome ruling provided little possibility for other litigants-also facing the state-to obtain counsel as of constitutional right. Lassiter required trial courts to make a case-by-case inquiry to determine whether, under the Matthews $v$. Eldridge balancing test, counsel would reduce the risk of error and then to weigh that judgment against what the majority termed a presumption against counsel in cases in which physical liberty was not at stake. See Lassiter, 452 U.S. at 31-32. Given the inefficiencies of making such an assessment, trial judges might either appoint counsel or decline; under either approach, reversal would be rare given that counsel would have shaped-or not shaped-a record reviewed on appeal.

After Lassiter, North Carolina altered its statutes, making a lawyer available to indigent parents faced with termination proceedings, and thereby joining the many states that had provided such a right by statute. See N.C. GEN. STAT. § 7b-1109(b) (1999). A recent Supreme Court ruling (on a right to state funding of transcripts when a litigant 
bedded within that conclusion was a more general assertion (actually, a rejection of a view that had almost gained currency) - that impoverished civil litigants in general do not have a constitutional right to counsel. ${ }^{35}$

Subsidies for disputes about parental status are provided not only on rare occasions to fund lawyers but also to fund the production of certain forms of evidence and to assist when litigants seek appellate review. In Little v. Streater, ${ }^{36}$ the Court required state-subsidized genetic testing when states sought to impose paternity obligations on putative fathers. ${ }^{37}$ And, more recently, in the 1996 ruling of M.L.B. $v$. $S . L . J .{ }^{38}$ the Court required states to provide transcripts to enable appellate review of termination of parental rights. To require a subsidy for this kind of litigant, and then only for this kind of litigant, required the Court to thread a complex path in light of contemporary equal protection and due process law. ${ }^{39}$ The Court concluded that its ruling (mandating funds for transcripts to enable appeals in termination cases) did not make "state aid to subsidize privately initiated action" generally available nor did it "alleviate the consequences of differences in economic circumstances that existed apart from state action. ${ }^{40}$ In other words, I can catalogue a series of rulings in which the Court, citing equal protection and due process doctrine, has concluded that state subsidies are required, and I can identify certain forms of family life as specially protected, but I cannot recount the theoretical bases through which the Court distinguished among arguably comparable contexts to order state subsidies for some subsets

appealed a ruling terminating her status as a parent) read Lassiter generously, suggesting a stronger right to counsel than the case-by-case weighing might have implied. See M.L.B च. S.L.J., 519 U.S. 102, $104-06$ (1996), discussed infra at notes $38-10$ and accom= panying text.

${ }^{35}$ See Lassiter, 452 U.S. at 25-27.

45 U.S. 1 (1981).

${ }^{97}$ See id. at 16-17 ("We hold that... to deny appellant blood grouping tests because of his lack of financial resources violated the due process guarantee of the Fourteenth Amendment.").

ss 519 U.S. 102, 128 (1996).

${ }^{39}$ See id. at 120-21 (discussing how alleviating such access barriers reflected both equal protection and due process concerns). Given current interpretations that equal protection violations need to be sustained by findings of intentional discrimination, due process "concerns" may well be the linchpin. The difficulty, however, is explaining why such concerns do not apply to other impediments to access to court or for other litigants. See id. at 129-30 (Thomas, J., dissenting). The analytic underpinnings of the state-subsidy requirement were similarly vaguely identified in Boddie v. Connecticut 401 U.S. 371, $387-89$ (1971) (Brennan, J., concurring).

40 M.L.B., 519 U.S. at 125 . 


\section{of litigants but not for others. ${ }^{41}$}

And, to summarize, save for such occasional exceptions, judges have not read the Constitution of the United States to require inroads into the unaided access premise. Which is not, of course, to say that no aid to civil litigants is provided but rather that little aid is provided through constitutional interpretation. Equipage for civil litigantsfrom filing fees to investigation to counsel to experts-is generally left either to the legislature or to the market. The Legal Services Corporation (with its recent restrictive regulations ${ }^{42}$ ) and in forma pauperis statutes $^{43}$ (with their newly circumscribed rights for prisoners ${ }^{44}$ and increasingly demanding evidentiary requirements ${ }^{45}$ ) provide the current federal legislative responses to the problems of poor people seeking to interact with the civil justice litigation system. ${ }^{46}$ Contingent fees and

41 For example, were one to want to elaborate a claim that funding is required when the state attempts to interrupt or to create familial relationships, then Lassiter's restrictive holding (that counsel is presumptively not provided unless a particular litigant can demonstrate special utility) is difficult to square with the as-of-right requirement of funding paternity tests stated in Little v. Streater. One could argue that funding lawyers is more expensive than funding genetic tests, but how to shape that into a constitutional principle imposing small but not larger subsidies is difficult.

${ }^{12}$ See Act of Apr. 26, 1996, Pub. L. No. 104-134, § 504(a), 110 Stat. 1321, 1353-54 (1999); 45 C.F.R. $\S \S 1612,1617,1626,1632,1639,1642$ (1999). See generally The Future of Legal Services: The Arthur Liman Colloquium Papers, 17 YALE. L. \& POL'Y REV. 281 (1998).

4 See 28 U.S.C. \$ 1915 (1994 \& Supp. III 1997). Congressional authorization for a waiver of fees dates from the Act of July 20, 1892, ch. 209, 27 Stat. 252, which provided that any "citizen" who was poor could commence or prosecute to conclusion any action in federal court without paying fees. See John MacArthur Maguire, Poverty and Civil Litigation, 36 HARV. L. REv. 361 (1923). Legislation in the early part of the twentieth century made such provisions applicable to appellate courts. See Act of July I, 1918 , ch. 113, 40 Stat. 634, 683.

Congress is currently revisiting the question of fee waivers for petitioners in bankruptcy, a possibility expressly left open by the Court in Kras $v$. United States, 409 U.S. 434,450 (1973). Pending legislation would permit fee waivers for some debtors after a demonstration of inability to pay the fee on an installment basis. See H.R. 833, 106th Cong. $\$ 148$ (Apr. 29, 1999) (House version); 146 CONG. REC. S393-401, S410-411, § 420 (daily ed. Feb. 7, 2000) (Senate version).

*See Prison Litigation Reform Act of 1995, Pub. L. No. 104-134, \$ 804, 110 Stat. 1321 (1996), codified at 28 U.S.C. $\$ 1915$ (b) (Supp. III 1997) (requiring prisoners with funds in their prison trust accounts to pay at least a portion of civil filing fees); In re Prison Litig. Reform Act, 105 F.3d 1131 (6th Cir. 1997) (describing implementation rules for that circuit). Thus far, lower courts have upheld such restrictions as rationally related to legitimate governmental objectives. See, e.g., Nicholas v. Tucker, 114 F.3d 17 (2d Gir. 1997).

${ }^{45}$ See, e.g., FED. R. APP. P. Form 4 (Affidavit Accompanying Motion for Permission to Appeal in Forma Pauperis) (requesting detailed information about applicants' assets).

${ }^{45}$ My discussion here is about litigation in courts. Two other arenas, administrative 
privately-funded organizations must do the rest.

\section{B. Ambivalence About Mandating Cross-Litigant Wealth Transfers}

Let me continue to focus on judicial interventions in the attorney fee market; judges are not, of course, limited to working only through constitutional interpretation. Judges make procedural rules and develop common law and, in each posture, have occasionally ventured into money matters. A familiar example is a federal rule of procedure that gives judges discretion to shift, at the conclusion of a lawsuit, a subset of litigation expenses-statutorily-defined "costs"-from losing to victorious parties. ${ }^{47}$ Note that a small body of case law worries about

proceedings and alternative dispute resolution, are increasingly relevant. Discussion of the limited powers of agencies to shift fees absent express statutory authority can be found in Unbelievable, Inc. v. NLRB, 118 F.3d 795, 799 (D.C. Cir. 1997) (concluding that the NLRB lacked such authority despite upholding a finding that an employer engaged in "aggravated misconduct" during negotiations). The Equal Assess to Justice Act ("EAJA"), 28 U.S.C.A. $\$ 2412$ (West Supp. 1999), authorizes fee shifting against the United States in a civil action but only if the government's position lacked "substantial justification." Administrative proceedings that involve adversary adjudication within an agency fall within the EAJA. See 5 U.S.C.A. $§ \S 504,554$ (West Supp. 2000). A host of administrative adjudication, however, falls outside.

Discussion of financial assistance for public participation in agencies during their regulatory proceedings can be found in Green Counly Planning Board v. Federal Power Commission, 559 F.2d 1227 (2d Cir. 1976) (en banc), cert. denied, 434 U.S. 1086 (1978) (concluding that the Commission lacked authority, absent congressional directive, to reimburse intervenors for legal expenses when challenging authorization of a construction for a power line); Simon Lazarus \& Joseph Onek, The Regulators and the People, 57 VA. L. REv. 1069 (1971) (discussing a "judicial model" for public involvement that would have agencies appoint counsel or pay legal fees to public interest groups and an "advocate agency model" that would entail the creation of a new federal agency to represent public interests before other agencies); Barry B. Boyer, Funding Public Participation in Agency Proceedings: The Federal Trade Commission Experience, 70 GEO. L.J. 51 (1981) (discussing that agency's statutory authority to fund public participation in agency processes); Stefan H. Krieger, An Advocacy Model for Representation of Low-Income Intervenors in State Public Utility Proceedings, 22 ARIZ. ST. L.J. 639 (1990) (attempting to develop a model of advocacy); and Carl Tobias, Participant Compensation in the Clinton Administration, 27 CONN. L. REV. 563 (1995) (discussing his efforts to involve the Executive in forwarding proposals for citizen participation in agency proceedings).

The interaction between alternative dispute resolution programs, some of which impose fees for use, and indigency is considered by John Maull, $A D R$ in the Federal Courts: Would Uniformity Be Better?, 34 DUQ. L. REv. 245, 262-69 (1996).

${ }^{17}$ See FED. R. Civ. P. 54(d); 28 U.S.C. § 1920 (1994). The procedural rule mixes the prior practice at law (in which, absent statutory negation, costs were always awarded) with that in equity (with discretionary awards of costs) by creating a presumption for the award of costs but leaving the decision to the discretion of the court. Congressional award of costs to the prevailing party dates from the First Judiciary Act. See Philip M. Payne, Costs in Common Law Actions in the Federal Courts, 21 VA. L. Rev. 397, 
the relationship between economic wherewithal and the propriety of shifting costs between loser and winner. ${ }^{48}$ John Noonan has provided us with a poignant example of the effects of ignoring such considerations. In his classic essay, The Passengers of Palsgraf, ${ }^{49}$ he discussed the New York Court of Appeals, which required Helen Palsgraf (who had won in lower courts but in 1928 lost her tort lawsuit on appeal) to pay the costs of the defendant Long Island Railroad, with its millions of dollars of assets. Noonan calculated the amount paid in costs as $\$ 350$, a sum he contrasted with Helen Palsgraf's earnings, estimated to be $\$ 416$ a year. ${ }^{50}$ In short, even in cost-shifting cases, judges have the opportunity and sometimes take the occasion to appraise both litigation validity and litigant economic capacity.

A second example of judicial intervention comes from the 1960s and $1970 s^{51}$ when some judges required losing defendants to pay vic-

401-02 (1935). At that time, the statutes addressing costs left open some questions about what items were included. See id. at 429. Some evidence suggests that attorneys' fees were billed as "costs," but federal practice came to rely on state rules, at least some of which precluded the inclusion of fees as costs. See also In re Peterson, 253 U.S. 300 (1920); CFARLES ALAN WRIGHT, ARTHUR R. MIILER \& MARY KAY KANE, 10 FEDERAL PRACTICE AND PROCEDURE $\$ 2665$ (3d ed. 1998) (describing the federal rule as adopting equity practice).

Today, taxable "costs" include items specified in 28 U.S.C. $\$ 1920$ (1999). FED. R. Crv. P. 68 also refers to costs; it provides that, if a plaintiff declines a defendant's offer and then receives less at trial, costs are shifted from the time of the offer, and costs may include more than those specified under $\$ 1920$ because of some statutes that define costs to include attorneys' fees. See Marek v. Chesny, 473 U.S. 1 (1985).

${ }^{48}$ The circuits have debated the permissibility of judicial inquiry into the financial status of winners and losers. Compare Stanley v. University of S. Cal., 178 F.3d 1069, 1079 (9th Cir. 1999) (calling on district courts to "consider the financial resources of the plaintiff and the amount of costs in civil rights cases"), and Wrighten v. Metropoli$\tan$ Hosps., Inc., 726 F.2d 1346, 1358 (9th Cir. 1984) (approving consideration of the "limited financial resources of a plaintiff" when costs are awarded), with Smith v. Southeastern Pa. Trans. Auth., 47 F.3d 97, 100 (3d Cir. 1995) (holding that financial disparity among litigants is not relevant to the costs awarded to prevailing parties), and Burroughs v. Hills, 741 F.2d 1525, 1542 (7th Gir. 1984), cert. denied, 471 U.S. 1099 (1985) (allowing district courts to deny costs only when a losing party is indigent). See also White \& White, Inc. v. American Hosp. Supply Corp., 786 F.2d 728, 730 (6th Cir. 1986) (mandating that lower courts usually ignore the prevailing party's own ability to pay its own costs); John M. Blumers, Note, A Practice in Search of a Policy: Considerations of Relative Financial Standing in Costs Awards Under Federal Rule of Civil Procedure $54(D)(1)$, 75 B.U. L. REV. 1541, 1544-51 (1995) (discussing reversals of district courts' discretionary rulings in cost awards related to financial ability to pay).

Reallocation of "costs" in aggregate litigation can involve significant amounts of money. See infra note 184 (discussing allocation of costs in the San Juan Dupont Plaza Hotel Fire Litigation).

49 See John T. NOONAN, JR, PERSONS AND MASRS OF THE LAW 144 (1976).

${ }^{30}$ See id. at 136-44.

${ }^{51}$ See, e.g., Hall v. Cole, 412 U.S. 1 (1973) (upholding equitable fee shifting from a 
torious plaintiffs' fees and costs based on the view that such private rights enforcement benefitted the public and hence that such "private attorneys general" should be compensated by those whom they sued. As one appellate court explained the rationale: "worthy claimants should not be discouraged from asserting rights embodying important public interests because of a lack of financial resources.,52

But in Alyeska Pipeline Service Co. v. Wilderness Society, ${ }^{53}$ the Supreme Court forbade judges from selecting litigants to reward for entering courts in pursuit of public norm enforcement. The Court ruled that private attorney general litigation-if deserving of assistance-would have to receive such support through legislative enactment; that Congress, not the courts, would have to decide what kinds of cases were to be subsidized and by whom (the state or the losing opponent). ${ }^{54}$ As is familiar, Congress has required fee shifting in many areas, both before and after Alyeska Pipeline.

Another judge-made mode of financing civil litigation is the equitable doctrine about fee sharing when common funds are created or common benefits conferred. ${ }^{56}$ This century-old doctrine is, however, born neither from the impulse to fund otherwise poor litigants to give them access to the justice system nor from distress that the adversary system is dysfunctional when the sides are mismatched, but from the need to correct free-rider problems. The equitable doctrine permits an already present and (importantly) victorious plaintiff to recoup the expenses of such vindication by taxing those who might benefit from but would not otherwise have to pay for that victory. Note that, were the common fund doctrine applied only to require that additional

defendant union to a lawyer for a union member, who had successfully challenged that union under the Labor, Management Reporting and Disclosure Act; congressional silence on the issue of fees was interpreted as permitting judicial discretion to award such fees).

${ }^{32}$ Incarcerated Men of Allen County Jail v. Fair, 507 F.2d 281, 282-85 (6th Cir. 1974) (discussing the emergence of an exception to the American rule so that those parties who acted as private attorneys general vindicating "a strong public policy" and providing "widespread public benefit through their efforts" could be paid by losing defendants).

s3 421 U.S. 240, 269 (1975).

34 "[C]ourts are not free to... pick and choose among plaintiffs and the statutes under which they sue and to award fees in some cases but not in others, depending upon the courts' assessment of the importance of the public policies involved in particular cases." Id. at 269.

${ }^{33}$ See, for example, the fee-shicting provisions in Section 4 of the Clayton Act, 15 U.S.C. $\$ 15$ (a) (1994), first enacted in 1914. A more recent fee-shifting provision can be found in the Family and Medical Leave Act, 29 U.S.C. $\$ 2617$ (a)(3) (1994), enacted in 1993.

${ }^{35}$ See, e.g., Trustees v. Greenough, 105 U.S. 527 (1881). 
people chip in to pay-but not to augment-a lawyer's fee, the rule would have only a marginal effect on the market for legal services. ${ }^{57}$ As used in the context of aggregate litigation, however, the fee has been calculated on the basis of the fund received by the aggregate. The common fund doctrine thus rewards lawyers who pursue such actions, thereby providing a means of enabling access to courts. Further, with expanded use, it becomes a means of court-awarded fees in the absence of statutes and contracts.

\section{Laissez-Faire Lawyering or Regulated Advocacy: Shifting Judicial Roles}

I have focused on the question of subsidies to provide a history of the justice system's posture towards financing litigation because one is lacking. I need say less about what I term laissez-faire lawyering because it is an aspect of familiar conceptions of the adversarial system in the United States. By using the phrase laissez-faire lawyering, I mean that judges have not much intervened to superintend attorneyclient relations or lawyers' presentations to judges. Under current law, clients are generally bound by decisions made for them by their lawyers. ${ }^{58}$ When civil and criminal litigants seek to avoid being held to their lawyers' decisions, judges generally refuse. Suits against lawyers for malpractice-rather than revisiting judgments made by lawyers in the underlying cases-are the primary means of redress.

But the second half of this century has also been a time of erosion of some aspects of laissez-faire lawyering. Judges now attempt to manage the interactions of lawyers with both other lawyers and the court

${ }^{37}$ See John P. Dawson, Lawyers and Involuntary Clients: Attorney Fees from Funds, 87 HARV. L. REV. 1597, 1601-03 (1974) [hereinafter Dawson, Lawyers and Involuntary Clients] (discussing as an "extra fee" money in excess of what the client who had retained the lawyer would have paid).

${ }^{33}$ See Link v. Wabash R.R, 370 U.S. 626, 634 (1962) (discussing how, in "our system of representative litigation ... each party is deemed bound by the acts of his lawyer-agent"). On the criminal side, lawyer decisions also bind clients. See Wainwright v. Sykes, 433 U.S. 72 (1977). Further, courts are not demanding of attorney-client relationships. See Morris v. Slappy, 461 U.S. 1, 13 (1983) (rejecting the claim that the Sixth Amendment right to counsel "guarantees a 'meaningful relationship' between an accused and his counsel"); Strickland v. Washington, 466 U.S. 668, 687 (1984) (refusing to reverse a conviction based on ineffective assistance of counsel by interpreting the Sixth Amendment right to counsel as requiring both a showing of attorney error and also that such errors affected the outcome to the defendant's detriment); Roe v. Flores-Ortega, $120 \mathrm{~S}$. Ct. 1029 (2000) (holding that criminal defense counsel's failure to file a notice of appeal without consulting with a defendant was not per se violative of the Sixth Amendment's right to counsel); see also note 22, supra. 
during the pretrial process. The impulse to regulate lawyers during the pretrial process has many sources. ${ }^{59}$ One is the growth of aggregate litigation. In the 1950 s, when confronted with large-scale litigation, judges altered many of their own practices in an effort to gain

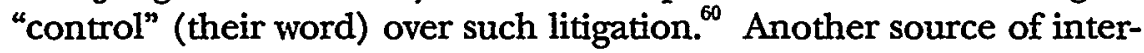
est in superintendence comes from the increasingly insistent focus on settlement. Judges who were enthusiastic about using pretrial processes as a springboard to resolution without trial began to direct attorneys to discuss settlement. Formal expression of this interventionist posture came with the revision of Rule 16 of the Federal Rules of Givil Procedure in $1983,{ }^{61}$ the enactment of the Civil Justice Reform Act in $1990,{ }^{62}$ the revision (again) of Rule 16 in $1993,{ }^{63}$ amendments to the discovery rules, ${ }^{64}$ and the Alternative Dispute Resolution Act of 1998.

In the 1980s, when discussing "managerial judges," a common assumption was that judges were managing cases. $^{66}$ It has become increasingly clear since then that judges are trying to manage lawyers.

${ }^{39}$ See Resnik, Changing Practices, Changing Rules, supra note 11, at 160 (discussing the development in the 1920s and 1930s in state courts of meetings between judges and attorneys to "pre-try" cases).

${ }^{60}$ See Handbook of Recommended Procedures for the Trial of Protracted Cases, 25 F.R.D. 351, 383-84 (1960) (recommending that "the judge assigned should, at the earliest moment, take actual control of the case" and rigorously exercise such control "from the time of filing to its disposition").

${ }^{61}$ See Amendments to Federal Rules of Civil Procedure, 461 U.S. 1095, 1100 (1983) (amending FED. R. Civ. P. 16).

${ }^{62}$ See Civil Justice Reform Act of 1990, 28 U.S.C. $\$ \S 471-482$ (1994). The Civil Justice Reform Act had a sunset provision. See 28 U.S.C. $\$ 471$ note (1994) (Implementation of Plans); see also The Civil Justice Reform Act of 1990 Sunsets Next Month, THIIRD BRANCH, Nov. 1997, at 6 (commenting on the termination of the Act and discussing the implications).

${ }^{6}$ See Amendments to Federal Rules of Civil Procedure, 507 U.S. 1089, 1116 (1993) (amending FED. R. GV. P. 16).

64 See Amendments to Federal Rules of Civil Procedure, 461 U.S. 1095, 1103 (1983) (amending FED. R. CV. P. 26); Amendments to Federal Rules of Civil Procedure, 480 U.S. 953, 975 (1987) (same); Amendments to Federal Rules of Civil Procedure, 507 U.S. 1089, 1118 (1993) (same); see also Proposed Amendments to the Federal Rules of Civil Procedure and Evidence, 119 S. Ct. 416, 455-68 (1998) (proposing additional amendments to Rule 26).

${ }^{65}$ See Alternative Dispute Resolution Act of 1998, Pub. L. No. 105-315, § 3, 112 Stat. 2993 (codified at 28 U.S.C.A. $\$ \S 651-658$ (West Supp. 1999)).

${ }^{68}$ See Resnik, Managerial Judges, supra note 11, at 376-78. Several judges had themselves spoken about their role as "case managers." See, e.g., Robert F. Peckham, The Federal Judge As a Case Manager: The New Role in Guiding a Case from Filing to Disposition, 69 CAL. L. REV. 770 (1981); Mark A. Costantino, Judges As Case Managers, TRIAL, Mar. 1981 , at 56. 
The alterations of the rules of procedure could be seen as attempting to generate different norms and ethics of lawyering. ${ }^{67}$ Hence, let me contrast the premise of laissez-faire lawyering with regulated advocacy, by which I mean this bundle of efforts by the judiciary to direct lawyers to pursue certain goals (settlement) by specific means (including various forms of alternative dispute resolution).

Some of that impulse to regulate lawyers comes from judicial work on fee applications under attorney fee-shifting provisions; the details provided by lawyers seeking reimbursement have been a source of unhappy revelations about lawyers' practices and their costs. Moreover, some of the pressure toward settlement comes from the perception that certain lawyers and clients seek to consume too much of the judiciary's resources and that it is necessary for judges to begin to impose restrictions on court time.

This point prompts articulation of yet another premise of civil justice, for which civil justice excess is my shorthand: that the system has too many cases $^{68}$ and, moreover, that it is inefficiently processing some of those that it has. ${ }^{69}$ Efforts to press towards settlement, as well as to adjust attorney behavior during discovery, to limit the number of federal causes of action, and to encourage other means of resolving disputes are responsive to such docket concerns.

\section{The Resultant Tensions}

Let me summarize the premises of the civil justice system as I have outlined them thus far. First, the Constitution mandates some equipage for litigants in criminal and quasi-criminal litigation. Second, courts considering the federal civil justice system have been reluctant to generate rules requiring taxpayer subsidies to civil litigants based on constitutional doctrine and have generally done so by establishing substantive due process rights related to physical liberty and parental status.

${ }^{67}$ Stephen Yeazell notes that rules of civil procedure, once made by judges and lawyers, are now increasingly made by judges. See Stephen Yeazell, Judging Rules, Ruling Judges, LAW \& CONTEMP. PROBS., Summer 1998, at 229.

${ }^{68}$ Concern about the docket of the federal trial courts increased during this century; reports from the Judicial Conference chronicle that concern, which has reached acute proportions during the last few decades. See Resnik, Transforming the Meaning of Article III, supra note 11, at 933-43.

${ }^{69}$ The effort to alter modes of judging, including using pretrial opportunities to manage and to settle disputes, is reflective of this concern. See Resnik, Changing Practices, Changing Rules, supra note 11, at 158-79. 
Third, courts welcome legislative responses that do more than what the constitutional floor provides. Given the polity's dependence on its justice system to enable as much equality and fairness as possible, legislative provisions to assist access have been encouraged by judges. Congress has not only created the Legal Services Corporation $^{70}$ and altered incentives through fee shifting when litigating certain causes of action, Congress has also regulated the fees of lawyers in a host of statutory schemes, such as those involving Black Lung, Social Security, and Veterans' Benefits. ${ }^{\text {"l }}$ And of course, tax dollar support runs to state attorneys general and the Department of Justice to provide civil enforcement litigation, some of it expressly in parens patriae status. $^{72}$

Fourth, judges have a long history of making modest interventions by means of common law development and rulemaking to require cross-litigant wealth transfers, either through cost shifting, experiments in attorney-fee shifting, or both fee and cost sharing. Those interventions have prompted some soul-searching about the relationship between money and justice. That introspection caused anxiety about judicial role. As a result, judicial doctrine is replete with requests for legislative direction and with rules of self-restraint.

Fifth, judges have been committed to non-intervention in the attorney-client unit and in the strategic interaction among parties during the course of litigation. Resources between litigants are not adjusted. Litigants retain their own counsel and are generally stuck with the representation afforded by whomever they select. However, and sixth, judges are becoming increasingly dissatisfied with lawyer behavior. Through rulemaking, judges have begun to make inroads into laissez-faire lawyering by attempting to regulate lawyers' advocacy to

${ }^{70}$ See Legal Services Corporation Act, 42 U.S.C. \$ 2996 (1994).

71 See Black Lung Benefits Act, 30 U.S.C. \& 932(a) (1994) (awarding fees for representation of mine workers with black lung disease); Social Security Act, 42 U.S.C. § 406(a) (1) (1994) (providing for fees for successful representation of claimants); Veterans' Benefits Act, 38 U.S.C. $\$ 5904$ (c) (3) (1994) (regulating allowable fees for representation of claimants).

72 See, e.g., The Civil Rights of Institutionalized Persons Act, 42 U.S.C. § 1997a(a) (1994) (granting, with restrictions, the Attorney General the right to initiate litigation on behalf of institutionalized persons); Clayton Act, 15 U.S.C. $\S 15 c(a)$ (1) (1994) (providing attorneys general of states a cause of action, parens patriae, for violation of federal antitrust laws); Children's Online Privacy Protection Act of 1998, 15 U.S.C. $\$$ 6504(a) (1) (Supp. IV 1998) (giving state attorneys general the right to sue, parens patriae, for such violations); Telemarketing and Consumer Fraud and Abuse Prevention Act, 15 U.S.C. $\$ 6103$ (a) (1994) (providing that states and the Federal Communications Commission could sue, parens patriae). 
courts.

That dissatisfaction interacts with a seventh premise, that the locus of activity of the civil justice system has shifted away from trials as a presumptive (albeit not frequent) endpoint. Today, trial is the endpoint expressly to be avoided. Settlement is the goal to which judges (in rulemaking and case law) and legislators (in statutes) regularly aspire, both in response to civil justice excess and as an end in its own right.

\section{AGGREGATE LITIGATION: WHAT IT BRINGS AND BUYS}

Turn now to aggregate litigation and its effects. Aggregation has been a long-term source of pressure on conceptions of the judicial role. For more than a century, judges in aggregate cases have understood themselves to be in a special relationship to absentees. Whether imposing taxes on absentees through the common fund doctrine or attempting to protect their interests by interpretations of res judicata and other preclusion doctrines, judges locate themselves as the guardians of non-litigants whose interests are implicated by a given litigation but whose participation is constrained. Further, as discussed above, the "big case" was one of the reasons why judges began to alter their attitudes about laissez-faire lawyering and to superintend presentations of cases. $^{73}$ Aggregate litigation also became a reason to question other premises - of unaided access to civil processing and of unregulated lawyering vis-à-vis clients. Aggregation sharpens the focus on inter-litigant equity and makes complex the posture judges should take towards settlement. Below, I detail the ways in which the evolution of procedural forms of aggregate litigation over the past five decades slowly unraveled several civil litigation traditions and became the means by which new aspirations developed. ${ }^{74}$

\section{A. Class Actions as State-Enabled Litigation}

By the 1960s, lawyers, judges, academics and legislators began to

${ }^{73}$ See Resnik, Changing Practices, Changing Roles, supra note 11, at 158-88; Judith Resnik, From "Cases" to "Litigation," LAW \& CONIEMP. PROBS., Summer 1991, at 5, 17-21 [hereinafter Resnik, From "Cases" to "Litigation"].

${ }^{74} \mathrm{My}$ focus is on procedural means of aggregation, but that development is interrelated with the evolution of substantive liability rules that imposed responsibility on an aggregate of individual entities. See, e.g., Sindell v. Abbott Labs., 607 P.2d 924 (Cal. $1980)$. 
conceive of civil justice as having characteristics readily associated with criminal justice and administrative systems: that it had the potential to serve as a venue for enforcement of public norms, and that, given other efforts to provide subsidies aimed at providing a small measure of redistributions toward the very poor, market interventions might also be appropriate within the civil justice system. ${ }^{75}$ The 1966 class action rule is one such expression of this new understanding.

The sources of this shift in attitude are multiple. New Deal regulations had focused on the utility of statutory protections for consumers and the desirability of the federal courts as a forum for redress. ${ }^{76}$ Civil rights litigation had highlighted the role of the federal courts in enforcing equality rights and the need for ongoing means of implementing injunctive decrees. Ambivalence about how much government actors could and should do also prompted interest in class action litigation. One risk was that government enforcement mechanisms could be captured by the very groups they were to regulate. Another concern was about the federal government gaining too much power. The language of privatization was not then in use but the impulse to privatize some law enforcement was attractive as a means of cabining federal power. ${ }^{77}$ Creating incentives for entrepreneurial private actors to use the civil justice system to partake in the work of public norm enforcement offered an alternative to centralizing power exclusively within government.

In such moments (occurring episodically in the history of the United States) of hospitality towards regulation, of engagement in issues of equitable wealth distributions, and of enthusiasm for entrepreneurism, the class action rule was born. Self-consciously, this rule challenged the etiquette established by the "unaided access" premise of the civil justice system by altering incentives. The class action rule

${ }^{73}$ Owen Fiss has made related points in his discussion of the function of adjudication, in which he contrasted a private "dispute resolution" model with what he called a structural reform model. See Owen M. Fiss, The Social and Political Fonndations of Adjudication, 6 LAW \& HUM. BEHAV. 121 (1982); see also Owen M. Fiss, The Political Theony of the Class Action, 53 WASH. \& LEE L. REv. 21 (1996) [hereinafter Fiss, Political Theory of Class Action] (arguing that the class action functions to fuse concerns of public officials and private citizens and that it provides a mechanism of funding so that those whose "private ends" have small economic value can pursue public interests).

${ }^{76}$ Compare the focus in Wilko v. Swan, 346 U.S. 427 (1953), on the regulatory role of litigation, with the vision of Rodriguez de Quijas v. Shearson/American Express Inc., 490 U.S. 477 (1989), which overruled Wilko and celebrated the dispute resolution approach to conflict.

$\pi$ See Harry Kalven, Jr. \& Maurice Rosenfield, The Contemporary Function of the Class Suit, 8 U. CFI. I. REV. 684 (1941). 
did so not by mentioning the " $F$ " word out loud (the 1966 text is silent on the subject of attorneys' fees) but by creating a rule regime under which lawyers had incentives to subsidize access to courts for small claimants otherwise unattractive to the contingency fee bar.

Government-imposed barriers to entering the public civil justice system were thereby lowered by government-crafted alterations of process. When lawyers purchased access but were unsuccessful in obtaining legal liability, they paid for courts to reach decisions but received no compensation for their time and had little hope of recouping costs from the unnamed persons on whose behalf they had ventured. However, the incentive for such lawyers to pay for others' use of the civil justice system came by virtue of the bonus, or bounty, available upon selecting winning claims. By aggregating many small claims together and establishing their legal validity, the victorious lawyer could garnish significant fees through the equitable common fund doctrine. Further, by creating such economic incentives, civil rulemakers helped to develop a cadre of lawyers (some of whom had gained expertise with regulatory regimes by working for the government) with specialized abilities, thereby making somewhat more level the playing field of civil justice when the class action rule was applied. $^{78}$

As we know from the notes and the archival materials about the class action rule, the drafters were deliberate about the arena for which they sought to alter market incentives. ${ }^{79}$ Small consumer claimants were inside and tort litigants were presumptively outside the aegis of their new rule. Moreover, we also know that the exclusion of mass torts came from several assumptions. First, there was the problem of "fit." Group litigation seemed inapposite to the individualized moment of physical injury represented in a tort. ${ }^{80}$ Second, federal group

${ }^{78}$ Alternatively, the prior regime, in which pooling of resources within civil justice was limited, could be viewed as having created artificial market impediments. Under such an approach, the 1966 class action rule removed barriers to free market exchanges. Yet other restrictions on lawyering behavior (derived from rules of procedure and/or ethics) could be seen similarly as limiting the range of market options and requiring revision. See, e.g., Macey \& Miller, The Plaintiffs' Attorney's Role, supra note 9.

${ }^{79}$ See Resnik, From "Cases" to "Litigation," supra note 73, at 9-10.

${ }^{80}$ See Benjamin Kaplan, Continuing Work of the Civil Committee: 1966 Amendments of the Federal Rules of Civil Procedure (I), 81 HARv. L. REv. 356, 393 (1967) (explaining that 'litigation from 'mass accidents' ... would ordinarily not be appropriate for class handling" because "individual questions of liability and defense will overwhelm the common questions"); Resnik, From "Cases" to "Litigation," supra note 73, at 10 (discussing Kaplan's correspondence describing 23(b) (1) (B) classes as "redolent of claims against 
litigation seemed ill-suited to a system of rights emanating, under Erie principles, from state law. Third, market interventions to enable access and provide lawyers for the unrepresented seemed unnecessary for tort litigants, already served by a contingency fee bar. Rule 23(b) (3) was specifically designed to correct a market impediment to access and rights enforcement for certain kinds of small claims, but not for ones sounding in tort.

Created by judges and lawyers working within the civil justice system and dissatisfied with its attitudes toward economic capacity and norm enforcement, class actions were thus a procedural form aimed at enabling litigation. Claims that would never have been pursued outside the group became viable, and the existence of a group of claimants changed some of the aspirations of the civil justice system, changed in some sense the "goods" that it was offering.

That the Supreme Court remained ambivalent about the project became clear through its rulings in Eisen $v$. Carlisle $\mathfrak{F}^{2}$ Jacquelin $^{81}$ and Coopers $\mathcal{E}^{2}$ Lybrand v. Livesay. ${ }^{82}$ Both cases reversed lower court judges who had taken the idea of the class action as enabling litigation to mean that additional interventions could be ordered under its umbrella. As is familiar, Eisen prohibited lower court judges from ordering defendants to pay the costs of notice in class actions in which plaintiffs had demonstrated a likelihood of success on the merits. ${ }^{83}$ Coopers $\mathcal{E}$ Lybrand $v$. Livesay refused appellate court review of the denial of class certification. Characterizing such rulings as interlocutory, the Court specifically rejected the argument that, because the plaintiffs could not afford to continue without class status, the denial of class certification was the "death knell" of the action, making it a "final" decision for purposes of appellate review. ${ }^{84}$

As Justice Stevens explained for the Court, it might well be true that, but for class certification, a lawyer would have to fold his/her tent and go home, but many other rulings in a procedural system could prompt a similar response. ${ }^{85}$ Indeed, virtually every ruling imposes economic costs on one side or the other in a litigation. Understanding that the issue of financial wherewithal was not limited to class

a fund" and thus not the context in which tort litigation occurred).

${ }^{81} 417$ U.S. 156 (1974).

${ }^{82} 437$ U.S. 463 (1978).

${ }^{23}$ See Eisen, 417 U.S. at 177-78.

84 At issue was interpretation of the finality of collateral orders and application of the finality concept of Cohen v. Beneficial Industrial Loan Conp., 337 U.S. 541 (1949). See Coopers \& Lybrand, 437 U.S. at 475-76.

${ }^{85}$ See Coopers \& Lybrand, 437 U.S. at 477. 
action certifications and refusing to make an exception for that category, the Court declined to place judges in the role of evaluators of claims' worth and of the utility of their pursuit. ${ }^{86}$ The Court also prohibited judges from relying on parties' representations of economic neediness as a basis for interim litigation subsidies. ${ }^{87}$

In short, the breadth of the judicial project of market intervention by way of class actions has been contested from its inception. One concern was the fear of flooding the system with too many claims. Another concern was enabling the wrong kind of claim, an anxiety that has resulted in complaints over the decades that this form of litigation is used to launch "highly speculative claims." ${ }^{\text {\$8 }}$ And the third concern was about judicial role: not only that judges were illequipped to sort deserving from undeserving litigants seeking entry but also that judges should not engage in such an evaluative enterprise to ease access to civil justice.

\section{B. MDLs as Regulatory Regimes}

That class actions raise hackles by reflecting shifts in the premises of the civil justice system is not news. But the way in which multidistrict litigation ("MDL") is disruptive of the premises of the civil justice system may be. ${ }^{89}$ Turn then from the 1966 class action rule to the 1968 enactment of the multi-district litigation statute, ${ }^{90}$ also a vehicle of aggregation. The MDL statute grows out of another feature of

${ }^{85}$ See id. at 476; see also Eisen, 417 U.S. at 177-78 (holding that judges were not permitted to hold hearings to learn the likelihood of success and, upon finding a probability of success, impose the costs of class notice on defendants).

${ }^{87}$ See Eisem, 417 U.S. at 176 . Legislative and rulemaking responses were not precluded, and Rule 23(f) stands as the contemporary answer, opening up the possibility of appellate review without having to reinterpret the requirements of mandamus, as Judge Rovner argued had occurred in In re Rhone-Poulenc Rorer, Inc., 51 F.3d 1293, 1304 (7th Cir. 1995) (Rovner, J., dissenting). Note that much of the interest in appellate review now comes from a claimed need to superintend district court excesses in certifying classes, in contrast to the focus in the 1970s, which was to obtain review of decisions denying class status. See Blair v. Equifax Check Servs., Inc., 181 F.3d 832 (7th Cir. 1999); see also infra note 119 (discussing appellate reversals of class action certifications).

${ }^{83}$ See, e.g., Cox, supra note 6, at 498. As Ed Cooper puts it, "whatever its successes, Rule 23 has generated undesirable and even nefarious class actions." Edward $\mathrm{H}$. Cooper, The (Clondy) Future of Class Actions, 40 ARIZ. L. REV. 923, 924 (1998).

${ }^{89}$ Providing another illustration of Stephen Yeazell's point about the unforeseen effects of procedural innovations, as well as another example of his specific concern about diminished appellate control over trial judges' decision making-in this instance of the power of MDL judges, once assigned. See Stephen C. Yeazell, The Misunderstood Consequences of Modern Civil Process, 1994 WIS. L. REv. 631.

${ }^{90} 28$ U.S.C. § 1407 (1994). 
twentieth century federal civil justice, what I called above civil justice excess. $^{91}$ Beginning in the 1950s with antitrust cases, judges taught each other to take control over what they then termed "protracted" (and what we now call "large-scale" or "complex") litigation," and (as I have mentioned) began to transform themselves into managerial judges, attempting to manage both cases and lawyers.

The MDL statute provides for the collection of many individual actions, grouped together for the pretrial process at the behest of either litigants or judges. ${ }^{93}$ Unlike the class action rule, the MDL impulse to aggregate was not premised on the social justice concerns of equipage and access, but on other kinds of resource concern-about waste and inefficiency. The redundancy in judicial time, the burdens on litigants of repeated exchanges over the same disputed factual materials, and the fear of potentially different and conflicting rulings from judges prompted the federal judiciary to propose, and Congress to enact, the MDL statute. ${ }^{94}$

The goals of economy of effort and reduction of duplication cannot, however, be realized without significant inroads into another aspect of civil justice etiquette-laissez-faire lawyering. Recall the background premise, that a client chooses its own lawyer and that lawyer is free (within constraints of rules) to build a case as he or she wishes. Judicial management starts to undermine that assumption, but the effects of MDL are far more disruptive because it disconnects lawyers from the clients who retained them. The aspirations for economy embedded in the MDL statute could not be achieved if all of the individual litigants' lawyers were permitted free rein.

So again, without saying anything out loud (the "F" word is not in the MDL statute either), provisions for multi-district litigation under-

${ }^{91}$ How to distribute access to litigation under such conditions is discussed by Robert G. Bone, in Statistical Adjudication: Rights, Justice, and Utility in a World of Process Scarcity, 46 VAND. L. REV. 561, 631-50 (1993).

${ }_{92}$ REPORT OF THE JUDICIAL CONFERENCE OF THE UNITED STATES ON PROCEDURE IN ANTI-TRUST AND OTHER PROTRACTED CASES (1951) (called the "Prettyman Report" after the Committee's chair), reprinted in Leon R. Yankwich, "Short Cuts" in Long Cases: A Commentary on the Report Entitled Procedure in Anti-Trust and Other Protracted Cases, Adopted by the Judicial Conference of the United States, September 26, 1951, 13 F.R.D. 41, $62-$ 64 (1953).

${ }^{93}$ See Lexecon Inc. v. Milberg Weiss Bershad Hynes \& Lerach, 523 U.S. 26, 40 (1998) (rejecting the practice of transferring MDL litigation to the transferee court for disposition and holding that the MDL statute provides for pretrial consolidation only).

${ }^{94}$ The statute was drafted by a subcommittee of the Judicial Conference, the Coordinating Committee for Multiple District Litigation in the United States District Courts. See Resnik, From "Cases" to "Litigation," supra note 73, at 29-32. 
mined this premise of the civil justice system by creating a procedure that would require lawyers to pool their resources, pursue pretrial discovery in concert, and designate spokespersons to appear before courts. When lawyers do not voluntarily select their own spokesperson, the MDL court appoints them, sometimes forming new collectives of lawyers, operating as an ad hoc law firm. ${ }^{95}$ In the wake of the MDL statute, the phrases "plaintiffs' steering committee" ("PSC"), "plaintiffs' management committee" ("PMC"), "plaintiffs' litigating committee" ("PLC"), "liaison counsel," and "joint document depository" ("JDD") have entered our lexicon.

These shifts in civil justice premises-regulated lawyering, assistedaccess, and efforts at economy-have not been lost on entrepreneurial lawyers, who saw the opportunity to use the civil justice system in new ways. Aggregate processing altered the ways in which the market of attorneys operate. The Eisen and Coopers $\mathcal{E}$ Lybrand rules require class action lawyers to have, or to amass, significant capital. The dynamics of the selection of "lead" lawyers in MDLs also put a premium on attorneys' economic capacity and sometimes their control over populations of clients. Plaintiffs' lawyers, based traditionally in small "boutique firms, ${ }^{, 96}$ began to enter into joint ventures to pursue a particular lawsuit with the requisite capital. ${ }^{97}$

Lawyers created consortia, developed new methods of financing litigation through investing, and expanded their client bases by union referrals, client-sharing, swapping, and warehousing. ${ }^{98}$ As these per-

${ }^{95}$ The Manual for Complex Litigation relied primarily on lawyer-based selection. See MANUAI FOR COMPLEX LITIGATION $\$ \S 1.92,4.53$ (5th ed. 1982) (stating that "Lead counsel are chosen by the groups of parties having a common interest"; in "exceptional circumstances" or when the parties fail to choose, courts may do so). Subsequent revisions of the Manual demonstrate increasing support for judicial control. See MANUAL FOR COMPLEX LITIGATION (SECOND) $\$ 20.224$ (1985) (advising judges to oversee appointment of steering committees); MANUAL FOR COMPLEX LITIGATION (TrIRD) $\S \S 20.222,20.224$ (1995) (recommending that judges take "an active part in making the decisions on the appointment of counsel"). See generally Thomas E. Willging, Beyond Maturity: Mass Tort Case Management in the Manual for Complex Litigation, 148 U. PA. L. REV. 2225 (2000).

${ }^{96}$ See Galanter, supra note 2, at $469-72$ (describing the structure and practices of plaintiff personal injury firms).

${ }^{97}$ See David Rosenberg, Class Actions for Mass Torts: Doing Individual Justice by Collective Means, 62 IND. L.J. 561 (1987) [hereinafter Rosenberg, Class Actions for Mass Torts]; David Rosenberg, Individual Justice and Collectivizing Risk-Based Claims in Mass Exposure Cases, 71 N.Y.U. L. REv. 210 (1996) (both celebrating such collective capacity of plaintiffs' counsel).

${ }^{98}$ See Resnik, Curtis \& Hensler, Individuals Within the Aggregate, supra note 2, at 31316. 
sonal injury lawyers gained expertise in working on large-stake litigation, the prestige of that part of the bar increased. Lawyers at "white shoe" law firms (themselves undergoing significant transformations) found themselves opposing personal injury lawyers acting in concert and in some instances earning more than they did.

The structure of the legal profession and its own class hierarchies began to shift. ${ }^{99}$ Defense firms started to organize around their distress. Bar associations sought measures to curb plaintiffs' lawyers, ${ }^{100}$ and defendants themselves sought bankruptcy protection, sometimes in a strategic effort to alter their interactions with plaintiffs. Ruptures among plaintiffs' lawyers emerged, with camps identified as the "class action" lawyers jockeying with those identifying themselves as representing individual tort victims, rather than groups. ${ }^{101}$ Some lawyers made money and others lost it in the process. ${ }^{102}$

No linear analysis captures all the interactive dynamics in the rapidly expanding and innovative market of aggregate litigation, changing even as I discuss it. ${ }^{103}$ But let me pull the various pieces of this history together. Aggregate litigation as it developed from the 1960s through the 1980 s provided a wedge that qualified the premises of

${ }^{99}$ See Galanter, supra note 2, at 469-70 (discussing the "upgrading of the plaintiffs' bar since World War $\Pi^{\prime \prime}$ ).

${ }_{100}$ See Florida Bar v. Went for It, Inc., 515 U.S. 618, 620 (1995) (upholding a Florida bar rule that plaintiffs' attorneys could not contact alleged tort victims until thirty days after an accident).

${ }^{101}$ See Coffee, Class Wars, supra note 9, at 1373. The impact of the changes within the span of a few years has been remarkable. Cases and areas of injury previously understood as immune from regulation via the civil justice system are now within its ken. For example, in the early 1990s when I taught a course with Deborah Hensler on Large-Scale Litigation, we used tobacco-related injuries as an example of a clearly harmful substance (in which issues of causation were straightforward) that stood outside the tort system, and contrasted it with injuries caused from exposure to chemicals that raised more complex causation questions. Not ten years later, tobacco litigation is central to our conversation, as it has become the latest exemplar of the utility and pitfalls of civil justice litigation.

${ }^{102}$ Aggregation of mass torts is assumed, ipse dixit, as an economy measure-saving resources, time, money, and human capital by avoiding redundancy when injuries are allegedly shared across a category of people. But litigation is a strategic interaction among multiple participants, and aggregation is not uniformly resource conservative. Sometimes resources of one set of participants are saved at a cost to another set of participants, who have to expend additional resources because of the fact of a large lawsuit.

${ }^{103}$ See DEBORAH R. HENSLER, BONNIE DOMBEY-MOORE, BETH GIDDENS, JENNIFER Gross, ERIK K. MOLLER \& NICHOLAS M. PACE, RAND INST. FOR GIVIL JUSTICE, CIASS

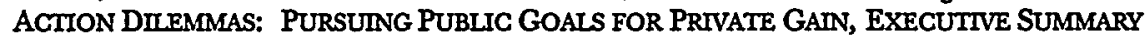
(1999) (book forthcoming spring 2000) (discussing shifts in class action practice, such as the growing number of damage class actions in state courts). 
laissez-faire lawyering and unaided access within the civil justice system. Class actions altered incentives not through public dollars but by turning to the private market. Class action practice was not, however, thought in the 1960s to raise questions about attorney-client relationships. The prototypical class actions-civil rights, limited funds, consumer class actions-assumed both a unity of interests among plaintiffs and a basic fungibility, in that each client suffered roughly the same injury. ${ }^{104}$ Further, single sets of lawyers (sometimes employees of organizations like the ACLU or NAACP) or single law firms represented the class as a whole. The economic rewards, awarded either by statutory fee shifting or by judicial application of the common fund doctrine, went to the firms or organizations that had filed the cases.

MDL litigations, in contrast, did not fit the single lawyer/fungible client model. MDLs aimed to collect cases already filed by an array of lawyers. Clients had lawyers but those lawyers were no longer their only lawyers, nor were those lawyers necessarily allowed to speak to the court on behalf of "their" clients. Interruption of and intervention in the attorney-client relationship resulted when judges selected a subset of lawyers with taking the lead. MDLs thus are a form of regulation of lawyers initiated by judicial redistribution (either through appointment or acquiescence in attorneys' decisions) of the power of lawyering. Jockeying for control became intense as courts approved fee awards to MDL lawyers who had served as spokespersons to defendants and to courts. Such a limitation of litigant autonomy became codified in federal law in another context, when, in 1995, Congress required judicial approval of lead counsel in securities litigation, even when such lawyers were selected by plaintiffs with the largest stakes in a litigation. ${ }^{105}$

\section{Inter-Litigant Equity}

Both MDLs and class actions also created a context in which another concern of civil justice came to the fore: that like cases be decided alike. That principle is oft-stated but in practice, until recently, loosely implemented. Let me call this "laissez-faire equity," which is to say that-without aggregation-the civil justice system could aspire to

${ }^{104}$ The imagined identity of interest among 23(b)(1) and (b)(2) classes, and hence, the absence of a requirement of notice and the assumption of a disunity of interest, requiring notice and an opportunity to opt out for 23(b) (3) class members, may be wrong in both directions. See Stephen C. Yeazell, From Group Litigation to Class Action: Part II: Interest, Class, and Representation, 27 UCLA L. REv. 1067, 1112 (1980).

${ }^{105}$ See, e.g., PSLRA, 15 U.S.C. § 77z-1 (a) (3) (B) (v) (1994 \& Supp. II 1996). 
inter-case equity but, given sequential case-processing across an array of courts, had no real means to implement it other than by reliance on preclusion doctrines such as non-mutual collateral estoppel. ${ }^{106}$

But once cases are aggregated-whether "only" for pretrial purposes or for all purposes-they can be compared; once compared, insight into distributional inequity emerges. Moreover, once aggregated, the net value of the litigation grows, thereby weakening the assumption (held by the 1966 class action ruledrafters) that tort cases could never involve "limited funds." ${ }^{107}$ The pot of money available might not only be badly distributed because of the variable quality of lawyering but also because of the happenstance of the time and place of filing. Some litigants might be at the end of a queue, seeking relief from resources exhausted by those in front of them. Distributional issues across sets of litigants are familiar ones in the criminal justice system, in which concern about sentencing disparity prompted the creation in the 1980 s of sentencing guidelines that rely on grids to reduce disparity. Discussions of inter-litigant equity have become a regular feature of civil justice discourse as well. Take a recent newspaper article, describing a settlement by eighteen asbestos makers who agreed to pay $\$ 160.6$ million to settle 4000 lawsuits. What made news was neither the fact of settlement nor the aggregate amount but rather that the awards were to be "based on where the victims lived, rather than on how sick the asbestos made them... The Mississippi residents got $\$ 263,000$ each, while Ohio, Indiana, and Pennsylvania residents who were hurt just as badly got $\$ 14,000$ each. ${ }^{108}$

Yet other premises of the civil justice system-that tort litigation is a quintessentially individualized process and, more generally, that aggregation is the exception-became qualified in the 1970s, 1980s, and 1990 s as practice shifted by the use in mass torts of MDLs, occasional

${ }^{106}$ The limits of the use of that doctrine (absent its reworking) in mass torts can be found in Hardy v. Johns-Manville Sales Corp., 681 F.2d 334, 347 (5th Cir. 1982) (refusing to apply preclusion against a range of asbestos defendants).

${ }^{107}$ As Ben Kaplan put it, "It seems to me that it would strain interpretation to say that particular actions by injured parties would "impair or impede the ability of the other members to protect their interests." Letter from Benjamin Kaplan to John Frank 2 (Feb. 7, 1963), Archives of Federal Rules Committee, Box 24 (quoted in Resnik, From "Cases" to "Litigation" supra note 73, at 10).

${ }^{108}$ Matt Moore, Asbestos Case Reaches Settlement, Associated Press, Jan. 24, 2000, available in 2000 WL 9750571. Further, "Texas residents got $\$ 43,000$ each.... An analysis of the total showed that if the plaintiffs received the money equally, each plaintiff would received approximately $\$ 41,000$." Id.; see also Stephen Labaton, Top Asbestos Makers Agree To Settle 2 Large Lawsuits, N.Y. TIMES, Jan. 23, 2000, at 22. Apparently, the settlement was sealed by the court but obtained by the press. 
class actions, informal consolidation, and the retreat by some defendants into bankruptcy. We became acculturated to tort litigation as just another kind of case in which aggregate processing achieved something useful for the civil justice system. ${ }^{109}$ And more and more kinds of cases seemed usefully grouped-not only within the federal system but also across jurisdictional lines. Without any specific statutory authority, federal judges from different districts met together in the 1950 s to respond to antitrust filings. ${ }^{110}$ In the 1980 s and 1990 s, again without statutory authority, judges from different jurisdictions (state/federal; state/state) came together to administer mass tort aggregates cooperatively. ${ }^{111}$

MDL litigation also made plain that judicial interest in economy (collecting cases together by consolidation) "matures" (to borrow Francis McGovern's metaphor ${ }^{112}$ ) into interest in enabling litigation. Economy came to be understood as meaning not only joint pretrial processing but also bringing a problem to its conclusion. If other cases are waiting in the wings, unfiled, economy prompts an interest in creating incentives to bring those other cases into being, to invite or to coerce future claimants or unfiled claims of current alleged victims "in"-all in pursuit of the (ever elusive) "global peace." Thus, the ALI Complex Litigation proposal creates a form of mandatory intervention, ${ }^{113}$ and we worry about how to find, identify, accurately de-

${ }^{109}$ David Shapiro goes further and argues that mass tort litigation not be conceived as aggregating individual claims but be understood as generating a discrete entity, the class. See Shapiro, supra note 2, at 917. George Priest argues that much of the reform effort around mass tort litigation is to enable it to provide forms of "plaintiff autonomy." Priest, supra note 10, at 527. My view, in contrast, is that while concerns about fairness and legitimacy dominate the discussion of tort class actions, the existence and persistence of aggregate litigation for torts demonstrates the degree to which that value has been superseded.

${ }^{110}$ See Resnik, From "Cases" to "Litigation," supra note 73, at 31-32.

111 Some commentators have argued that these practices should be a source of concern. See Francis E. McGovern, Rethinking Cooperation Among Judges in Mass Tort Litigation, 44 UCLA L. REV. 1851, 1866-70 (1997). Descriptions of the practices can be found in Helen E. Freedman, Product Liability Issues in Mass Torts-Views from the Bench, 15 TOURO L. REv. 685 (1999); Sam C. Pointer, Jr., Reflections by a Federal Judge: A Comment on Judicial Federalism: A Proposal To Amend the Multidistrict Litigation Statute, 73 TEX. L. REV. 1569 (1995); and William W Schwarzer, Nancy E. Weiss \& Alan Hirsch, Judicial Federalism in Action: Coordination of Litigation in State and Federal Courts, 78 VA. L. REV. 1689 (1992). Discussion of such efforts as instructive forms of invention within United States federalism is provided in Judith Resnik, Afterword: Federalism's Options, 14 YALE L. \& POLY REV./YAIEJ. ON REG. 465, 480-81 (1996).

${ }^{112}$ See Francis E. McGovern, Resolving Mature Mass Tort Litigation, 69 B.U. L. REV. 659,659 (1989).

${ }^{113}$ ALI, COMPLEX LITIGATION, supra note $1, \S 5.05$, at 278 ("The intervention 
scribe, represent, and compensate individuals not yet seeking remedy, but whom we believe are (or ought to be) understood as affected by the decision. MDL starts to blur with class action practice, and together they both undermine the laissez-faire premises of the civil justice system-that judges handle civil cases singly, that folks find their own lawyers, pay them as they please, live with their mistakes, and may or may not make their way into the civil justice system.

\section{Insufficiently Regulated Civil Justice}

To summarize, the blossoming of aggregate litigation (by a variety of means including class actions, MDLs, bankruptcy, and informal groupings) forms and reflects major shifts in several premises of the civil justice system. No longer does the civil justice system take everyone as they come. It now offers subsidies and incentives to enter, at least for those whose alleged injuries are widely shared. No longer does the civil justice system ignore the problems of inequality between litigants; for certain kinds of litigants, it provides a means to balance the scales by enabling plaintiffs to pool resources. No longer does the civil justice system always let clients select the attorneys who will speak for them; it sometimes creates relationships among lawyers and individuals whom they have never met. No longer does the civil justice system permit lawyers to choose courses to pursue; it manages their options and orients them toward settlement. No longer does the civil justice system prize individual autonomy particularly when bodily harm is at issue; it now mandates group processing-not only when litigants appear fungible but also when claims within classes of litigants vary but are linked by an underlying source of injury. No longer does the civil justice system turn a blind eye toward distributional inequity; it creates claims facilities (amalgams of insurance companies, mini-court systems, and specialized agencies), which attempt to map a host of injuries and distribute justice by locating individuals on a grid (in a mode made familiar by sentencing guidelines).

Yet, despite these many transformations moving in the direction of subsidy, market interventions, and regulation, one aspect of the old civil justice etiquette remains in place. Judges remain reluctant to talk about how much which lawyers are being paid to do what kind of work in the incompletely regulated regime of civil justice that has

scheme is really designed to be coercive, not compulsory; the individual retains the option to join the suit or not, but is confronted with a risk of being bound to an adverse judgment should he decide to stay away."). 
emerged. ${ }^{114}$ The mountain of case law, the symposia, and the proposals, however, provide evidence that the normative challenges of deciding which of the competing civil justice premises to reward has become harder. Further, the Supreme Court's recent decisions in one kind of aggregate litigation, class actions, instruct judges that their efforts to craft dispositions have not succeeded in protecting rights of representation that the Court insists remain vital to the civil justice system.

Return then to the interaction among aggregation, mass torts, and settlement. Three routes are, conceptually, available-to retreat from aggregate processing, to retreat from settlement of aggregates, or to focus on how judges could develop legal regimes that structure their engagement with the aggregate settlements in which they are critical participants. Consider first the possibility of a dramatic retreat from aggregate litigation by a refusal to handle an array of claimants in groups and a return to the world in which lawyers and clients found each other, fended for themselves, and, if and when they filed lawsuits, proceeded single file. That impulse (in not quite as stark a form) is plainly attractive to some legislators, judges, and commentators. In the fall of 1999, a front page article in the New York Times announced: "House Passes Bill That Would Limit Glass-Action Suits."115 Some members of Congress perceive federal courts to be less hospitable to class actions than certain states and therefore propose to make federal courts the presumptive venue for class actions. ${ }^{116}$ Other pending proposals shift categories of cases-such as asbestos-from the courts into the administrative-court arena. ${ }^{117}$ Judges have similarly expressed distress, both at the Supreme Court level ${ }^{118}$ and in several fed-

${ }^{114}$ And unlike Cass Sunstein's argument about the joys of what he terms "minimal adjudication," minimalistic regulation has less utility in this context. CASS $R$. SUNSTEIN, ONE CASE AT A TIME: JUdictal MINIMAIISM ON THE SUPREME COURT (1999).

${ }^{115}$ Stephen Labaton, House Passes Bill That Would Limit Class-Action Suits, N.Y. TIMES, Sept. 24, 1999, at AI.

${ }^{116}$ See Interstate Class Action Jurisdiction Act of 1999, H.R. 1875, 106th Cong. (1999) (passed by the House on September 23, 1999 and providing for removal of "interstate ${ }^{n}$ classes to the federal courts).

${ }^{117}$ See Fairness in Asbestos Compensation Act of 1999, H.R. 1283, 106th Cong. (1999); Fairness in Asbestos Compensation Act of 1999, S. 758, 106th Cong. (1999) (sent to committees on May 25, 1999); see also Stephen Labaton, How a Company Lets Its Cash Talk, N.Y. TIMES, Oct. 17, 1999, § 3, at 1 (discussing the lobbying efforts).

${ }^{118}$ See Ortiz v. Fibreboard Corp., 119 S. Ct. 2295, 2302 (1999) (describing the "elephantine mass of asbestos cases" as defying "customary judicial administration" and calling for a legislative response); Amchem Prods., Inc. v. Windsor, 521 U.S. 591, 598 99 (1997) (also urging a congressional response). 
eral circuits, which have attempted to constrain the trial bench's enthusiasm for aggregate processing. ${ }^{119}$

Yet class actions still have their champions in state and federal courts. Many trial judges, less buffered from needy litigants than appellate judges, are acutely aware of injuries suffered by groups of plaintiffs, of the lack of congressional responses to date, of inequitable distribution patterns generated by case-by-case decision making, and of the inability of courts to render enough of those case-by-case decisions. Such judges continue to certify classes and help to craft settlements for some of them. ${ }^{120}$ Moreover, despite its distress, the Supreme Court did not counsel abandonment of settlement class actions in mass torts but rather sought better process for them.

Further, to locate class actions as the "problem" ignores that class actions are but one vehicle by which mass torts (and other kinds of cases) are aggregated. In the debate about aggregation, class actions themselves serve a representative function, standing for a range of aggregate forms. To reject aggregative court-based processing of claims would require Congress and the courts to eliminate or to restrict access not only to class action litigation but also to the multi-district litigation statute, to bankruptcy (with its prepackaged and prenegotiated distribution plans), to interpleader, to consolidation, and to informal pretrial management which groups cases together. ${ }^{121}$

${ }^{119}$ For decisions overturning certifications see, for example, In re Rhone-Poulenc Rorer, Inc., 51 F.3d 1293, 1294 (7th Cir. 1995) (using its mandamus jurisdiction to reverse certification of a class on behalf of hemophiliacs receiving blood transfusions); In re American Medical Systems, Inc., 75 F.3d 1069, 1074 (6th Cir. 1996) (decertifying a class suing for allegedly defective penile implants); Valentino v. Carter-Wallace, Inc., 97 F.3d 1227, 1230 (9th Cir. 1996) (decertifying a class seeking redress for alleged injuries from a drug for epilepsy); and Castano v. American Tobacco Co., 84 F.3d 734, 737 (5th Cir. 1996) (decertifying a class including "all nicotine-dependent persons in the United States... who have purchased and smoked cigarettes manufactured" by the defendants).

Let me be sure that, as I sketch the conflicts, I am not heard to suggest that heroes are all on one side, and villains are on the other. Newspaper reports provide painful evidence of some truly awful lawyers, some utterly self-interested ones, some inattentive judges, and some overzealous ones. But most of the participants are attempting to craft makeshift solutions in contexts about which they are deeply troubled. This is the world of "second best" responses, keenly felt but differently assessed at both trial and appellate levels and by an array of lawyers and commentators.

${ }_{120}$ See, e.g., Petrovic v. Amoco Oil Co., 200 F.3d 1140, $1144-45$ (8th Cir. 1999) (upholding a district court approval of a settlement involving damages for pollution over objections, some of which were predicated on Amchem and Ortiz); In re Austrian \& German Holocaust Bank Litig., 80 F. Supp. 2d 164, 167 (S.D.N.Y. 2000) (approving a settlement against Austrian banks).

${ }^{121}$ Discussion of the overlap between class actions and bankruptcy in function and 
In other words, procedural innovations did not create the new civil justice system, and procedural retrenchment cannot erase the many reasons that have pressed a disparate group of rulemakers, lawyers, and litigants to move toward group-based processing. The technologies of construction, air travel, engineering, photocopying, computers, and the Internet have transformed both the problems with which the legal system has to cope and the legal system itself. Mass marketing of products, the structure of insurance, the desire of corporate defendants to circumscribe liability, the marvelous interactional information capacities generated by the web, and the painful inequalities thus revealed continue to create powerful incentives to find ways of responding to widespread injury by more than the familiar-but insufficient-single-file, laissez-faire, unaided civil justice system.

The late 1990s do not seem much like the early 1960s in terms of political interest in state-subsidies for poor people. But the transformations of these decades - of legal culture, of the structure of law firms, of technological capacities to identify harms shared across individuals, of judicial concern about docket sizes and equity among claimants-make it unlikely that group litigation will fade away. ${ }^{122}$ Some forms of aggregation are here to stay. Rather than reject class action regimes, some of their procedural attributes (including obligating judges expressly to authorize class actions and to undertake repetitive inquiry into the adequacy of representation ${ }^{123}$ ) should be borrowed and elaborated as a means of controlling worrisome practices less regulated in some of the other aggregate forms. ${ }^{124}$

Given that aggregation has a vitality that makes it unlikely to be dislodged, then a second option is to reject settlement as a means of disposition in aggregate mass torts. Because some of the contemporary challenges now entailed in judging are artifacts of aggregation

conceptual challenges is found in the essay for this Symposium by Alan Resnick. Alan N. Resnick, Bankruptcy As a Vehicle for Resolving Enterprise-Threatening Mass Tort Liability, 148 U. PA. L. REV 2045 (2000).

${ }^{122}$ And the effects of aggregate processing have been felt across the litigation spectrum, from the aggregate to the individual case, as aggregation has helped to push courts towards individual calendars, judicial case management, innovative methods of dealing with experts, active participation in the structuring of large-scale settlements, and exploration of a range of state-federal coordination.

${ }^{123}$ See FED. R. CTV. P. 23(a), (b), (e) (obliging judges at certification to assess the adequacy of representation and then to return to the issue when considering proposed compromises and dismissals of class actions).

${ }^{124}$ See supra note 108 (discussing an asbestos settlement-done as a bundle but without, apparently, class action status, in which recoveries vary by location of the victim rather than by degree of injury). 
mixed with policies that favor settlement and incentives to induce it, ${ }^{125}$ judges could try to alleviate the difficulties by offering only adjudication. Courts do not have to be in the business of providing contractual agreements with the imprimatur of "judgments of the court." Judges could alter yet another longstanding practice of the civil justice system-the provision of consent judgments-by abandoning that procedural form as a relic of days when courts were the only institution able to notarize contracts and thereby to provide proof of the fact of agreement. ${ }^{126}$ Notarized contracts can now attest to parties' agreements, and lawyers could negotiate multi-faceted, multi-party contracts. If arguments arose about authority to consent or breach, contract law would have to respond. And judges could serve only when asked to render judgments on contested claims presented by parties in conflict. Judges and/or juries could rule on issues, including the ways in which claimants were factually or legally distinct and which agency relationships merited legal recognition. Law, rather than consent, could thus set the parameters.

I myself am often identified as a settlement skeptic, keenly aware that it licenses judges to do more than what law requires. ${ }^{127}$ Others have raised questions about the constitutionality of settlement roles for Article III judges, particularly as they enable litigants to contract out of state law requirements. ${ }^{128}$ And Congress has recently limited the availability of settlement in one aggregate setting: prisoners' rights cases seeking to alter conditions of confinement. ${ }^{129}$ Were such

${ }^{125}$ See Peter H. Schuck, Judicial Avoidance of Juries in Mass Tort Litigation, 48 DEPAUL L. REV. 479, 487 (1998).

${ }^{126}$ See Judith Resnik, Judging Consent, 1987 U. CHI. LEGAL F. 43, 50-56 [hereinafter Resnik, Judging Consent] (describing the historical bases for consent judgments and decrees).

${ }^{127}$ See id. at 44; Resnik, Managerial Judges, supra note 11, at 380. I am also leery of judicial efforts to use the status of the Article III judiciary to lobby Congress to enact certain causes of action or to repeal or decline to enact others. See Resnik, Transforming the Meaning of Article III, supra note 11, at 1020-31. My suggestions, below, for recognition of the new roles that aggregation brings to judges are not in tension, in that I seek judges to be engaged in lawmaking, rather than in less visible modes of negotiation.

${ }^{223}$ See Paul D. Carrington \& Derek P. Apanovitch, The Constitutional Limits of Judicial Rulemaking: The Illegitimacy of Mass-Tort Settlements Negotiated Under Federal Rule 23, 39 ARIZ. L. REV. 461 (1997); Henry Paul Monaghan, Antisuit Injunctions and Preclusion Against Absent Nonresident Class Members, 98 ColuM. L. REv. 1148, 1159 n.48, 1165 n.73 (1998).

${ }^{129}$ See Prison Litigation Reform Act, 18 U.S.C. § 3626(c) (1) (Supp. IV 1998) (permitting the reopening of consent decrees and precluding their enforcement without renewed factfinding to establish federal law violations). The constitutionality of one of the act's provisions, providing "automatic stay[s]" of decrees upon motions filed chal- 
concerns to move both legislative and judicial officials to alter their enthusiasm for settlement, and therefore to revise statutes, rules, and practices that both celebrate and create incentives for settlement, such a retrenchment could moderate some of the problems of mass tort aggregates.

But doing law rather than settlements in mass torts has its own conceptual challenges. Consider Judge Robert Parker's many attempts at innovation in his decades of work on asbestos cases-including seeking to apply preclusion law to avoid relitigation of certain questions ${ }^{130}$ and structuring trials from which to extrapolate values for an aggregate. ${ }^{181}$ Neither got further with appellate courts than did his efforts to effectuate a settlement in Ortiz As Judge Higginbotham counsels, ${ }^{132}$ such adjudicatory efforts should be pursued (and admired) but, whether by settlement or adjudication, a great deal of ingenuity and doctrinal expansion is required when claimants are aggregated because the fundamental problems-representational integrity and equitable distribution-are artifacts of aggregation and of an understanding that the underlying injuries are shared and overlapping.

Hence, it is the third route-judicial engagement with and development of the law of aggregates through the processes of settlement and adjudication - that is, in practice, demanded. Moreover, the two categories, settlement and adjudication, themselves blur when understood through the lens of contemporary litigation. The rulings in Amchem and Ortiz require that judges get better at "judging consent" (an act I have long thought to be problematic both conceptually and practically ${ }^{133}$ ). Judges will have to decide whether parties' contracts,

lenging their continuing viability, is before the Supreme Court. See French v. Duckworth, 178 F.3d 437, 446 (7th Cir.), cert. granted, 120 S. Ct. 578 (1999).

${ }^{130}$ See Hardy v. Johns-Manville Sales Corp., 509 F. Supp. 1353, 1363 (E.D. Tex. 1981), rev'd, 681 F.2d 334 (5th Cir. 1982).

${ }_{131}$ See Cimino v. Raymark Indus., Inc., 751 F. Supp. 649, 653 (E.D. Tex. 1990), rev'd on this issue, 151 F.3d 297, 314-21 (5th Gir. 1998); see also In re Chevron U.S.A., Inc., 109 F.3d 1016, 1021 (5th Cir. 1997) (prohibiting sample trials from having preclusive effect in a litigation involving claims of contamination by 3000 plaintiffs against a former land owner); $c f$. Hilao v. Estate of Marcos, 103 F.3d 767, 784 (9th Cir. 1996) (relying on sampling to determine compensatory damages for some 9000 plaintiffs seeking relief under the Alien Tort Claims Act for human rights abuses). See generally Robert G. Bone, Statistical Adjudication: Rights, Justice, and Utility in a World of Process Scarcity, 46 VAND. L. REV. 561 (1993) (evaluating the normative bases for sampling).

192 See Patrick E. Higginbotham, Thoughts About Professor Resnik's Paper, 148 U. PA. L. REV. 2197, 2204-06 (2000) (proposing greater reliance on subclasses and efforts to increase insistence on trial).

${ }^{13 s}$ See Resnik, Judging Consent, supra note 126. 
structured by lawyers (sometimes with judicial involvement) should be endorsed by law. To do so, judges will have to turn settlement hearings into a closer approximation of adjudication than they have in the past. Judges will need to obtain competing descriptions of the quality of the settlements proposed, which is to say that some form of adversarial process is now necessary. Such a hybrid mode of disposition, drawing on both adjudication and settlement, might usefully be understood as an adjudicatory settlement, ${ }^{134}$ distinct from a "regular" settlement in which a judge currently plays almost no role. ${ }^{135}$

Given that settlement is predicated on agreement and adjudication on oppositional stances, where do adversaries and independent evaluators come from when settlements are in the offing? The problem-as those close to mass tort litigation well know-is that pigeonholing even plaintiffs and defendants into oppositional roles is sometimes inaccurate. The fluidity of alignments makes references to Calder mobiles rather than to rigid triangulation better descriptions of mass tort litigation; those interactions led Jack Coffee to label some of those overlapping alignments "collusive."136 At some points during such litigations, claimants' representatives are co-venturers, sometimes even with subsets of defendants, and at other points, they splinter. ${ }^{137}$

134 The Supreme Court understood, when imposing its requirements, that such complexity makes for problems of coordination and that such strategic interactions will make settlement more difficult to achieve. See Amchem Prods., Inc. v. Windsor, 521 U.S. 591, 636 (1997) (Breyer, J., concurring in part and dissenting in part) (" $[\mathrm{T}]$ he more subclasses created, the more severe conflicts bubble to the surface and inhibit settlement...." (citation omitted)).

${ }^{135}$ That role may also be shifting. In some states, judges have been charged with overseeing (either through legislative directive or by common law development) "structured settlements," which are payments made to individuals to release claims but, in contrast to traditional settlements, the payments are made periodically, over a term of years. See, e.g., 215 IIL. COMp. STAT. ANN. 5/155.34(a) (West Supp. 1999) (prohibiting insurance companies from making payments on a structured settlement in personal injury litigation to anyone other than the beneficiary "without prior approval of the circuit court"); CONN. GEN. STAT. ANN. \$ 52-225f (West Supp. 1999) (requiring court approval of transfers of rights in structured settlements). For discussion of the secondary market developed to enable litigants receiving such settlements to cash out early, see David Dreher, The Ethics of Structured Settlements: Proposed Restraints on Factoring and Attorney Conduct 9-26 (Jan. 25, 2000) (unpublished manuscript on file with the University of Pennsylvania Law Review). Discussion of interest in regulating bargaining in criminal cases can be found in Abraham S. Goldstein, Converging Criminal Justice Systems: Guilty Pleas and the Public Interest, 49 S.M.U. L. REv. 567 (1996), and in Nancy Jean King, Priceless Process: Nonnegotiable Features of Criminal Litigation, 47 UCLA L. REV. 113 (1999).

${ }^{136}$ Coffee, Class Wars, supra note 9, at 1357-84.

${ }^{137}$ See, e.g., In re San Juan Dupont Plaza Hotel Fire Litig., 907 F.2d 4, 4-5 (1st Cir. 1990) (describing differing alignments during various phases of the litigation). 
Moreover, objecting lawyers may emerge not because of flaws in the remediation package proposed for claimants, but because they seek larger fees for themselves and hope to be "bought off."

Here is where money matters. Who pays whom for the work done on behalf of the civil justice system that now refuses to accede to multi-party agreements without assurances of multi-faceted representation? During what phases do lawyers representing distinct interests have to work separately, rather than together? While doctrines such as the common fund supply ample economic incentives for high and middle-end claimants to be represented, who will undertake to advance the interests of claimants with low-value injuries in aggregates, some of which involve not thousands of claims but only hundreds, resulting in small aggregate recoveries? Further, who will police those representatives to ensure their stances are not simply obstructionist? Although the Supreme Court's recent decisions clarify (or impose) such responsibilities on the trial bench, the Court has not explained how judges are to discharge them.

Return to the image of judges as purchasers and allocators of legal services. Understand now that the "value" of aggregation accrues not only to the litigants but also to the civil justice system, concerned about the processing of a high volume of disputes, eager to accomplish inter-litigant equity, and desirous of policing inappropriate attorney behavior. Moreover, the reliance on settlement helps to vindicate a range of public aspirations for the civil justice system. Therefore, the "value" of such tort aggregate settlements cannot only be measured by the dollars paid to the litigant cohort, but also must take into account the benefits bestowed on the civil justice system, which becomes able to process a group of similarly situated claimants in a fashion that does not undermine the legitimacy of courts.

Trial judges who continue to want to approve settlements of mass torts will have to start developing the law of fees, subsidies, and costs to specify the relationship between compensation to lawyers and conceptions of separate representation. Trial judges will have to start paying for process-either through state subsidies or by reallocating moneys among attorneys inside (or outside) mass torts. Translating Amchem and Ortiz into reality requires acknowledgment of the degree to which the civil justice system has moved away from the precepts of laissez-faire lawyering and unaided access. Judges, now required to regulate advocacy by lawyers, will have to refashion the incentives of lawyers to ensure that subclasses of varying economic values all receive 
quality representation. ${ }^{138}$ To do so, judges will have to monitor affiliations of lawyers by learning about the economic relationships among lawyers.

Return then to the Supreme Court's decision in Coopers $\mathcal{E}^{2}$ Lybrand v. Livesay, in which the Court stated that judges should not $b e$ in the business of evaluating the utility of a case, that procedural rules (in that context, access to appellate review) could not be altered to take into account the economic wherewithal of group litigants and the desirability of their pursuing claims in court. ${ }^{139}$ Return also to Alyeska Pipeline Service Co. v. Wilderness Society and the Court's ruling that judges should not select categories of cases for which to require subsidies. ${ }^{140}$ My argument is that these premises have been overruled in practice because aggregate litigation unavoidably puts judges into such a position, that judges cannot ignore these consequences of the aggregates they participate in creating, and that judges should respond by developing laws and rules to guide themselves, as well as others.

\section{TALKING ABOUT MONEY}

\section{A. Judges as Purchasers of Services}

The tasks that remain for this essay are to sketch how judges (either when deciding cases, drafting rules, or urging legislative action) should approach their work, as they create and participate in aggregates not only as fiduciaries for but functionally as clients. My focus on judges comes from my sense that, while congressional directives and Supreme Court reevaluation of the strictures of its equal protection and due process interpretations would be useful, comprehensive directions from either Congress or the Court are unlikely. The turn to judge-made rules is a pragmatic one, tinged with hope; the very act of constituting aggregates brings judges into direct contact with the issues and may well help them (and therefore the polity) to develop informed, context-specific responses to the challenges posed. Because my claim is that judges are not only mimicking the market when setting fees ${ }^{141}$ but are the market, ${ }^{142}$ my questions are about how judges

${ }^{139}$ See Cox, supra note 6 , at 499, 550-59 (arguing that, in the context of securities litigation, judges must be the "guardian [s] of the class action's virtue").

${ }_{139} 437$ U.S. 463,476 (1978); see also supra notes $82-86$ and accompanying text.

${ }^{140} 421$ U.S. 240, 269 (1975); see also supra notes 53-55 and accompanying text.

${ }^{141}$ See, e.g., Henry v. Webermeier, 738 F.2d 188, 193 (7th Cir. 1984) (shaping rules in civil rights suits to resemble the market). 
should use their market power. One concern is that such power could be used by judges to attract "interesting" cases to their courts, a problem identified in bankruptcy law. ${ }^{143}$ My focus here, however, is on how judges should use their purchasing power to structure mass tort aggregate litigation to enhance its utility for the civil justice system.

The catalogue of what judges have become accustomed to paying for provides a beginning. Be it by means of a lodestar or percentage of the fund, either ex post or ex ante via an auction, ${ }^{14}$ judges have approved payments to lawyers for creating the economic value of common funds; ${ }^{145}$ investing time; ${ }^{146}$ providing access by lending funds to pursue claims; policing access by evaluating claims and serving as gatekeepers; taking risks; ${ }^{147}$ enforcing and vindicating public norms

${ }^{112}$ Judge Grady makes a related point, that judges set prices by relying on each other, thereby developing a "common law of fees." Grady, supra note 16, at 141. "Each large award is duly recorded and cited to the next judge in a continuing escalation." Id.

${ }^{145}$ Evidence that lawyers understand judges to be "the market" comes from bankruptcy practice, in which "judge shopping" (rather than "forum shopping") may be prompted by differing fee practices of some judges. Moreover, not only are lawyers seeking certain judges, judges are also eager to attract "interesting" cases. See Lynn M. LoPucki \& William C. Whitford, Venue Choice and Forum Shopping in the Bankruptcy Reorganization of Large, Publicly Held Companies, 1991 WIS. L. REV. 11, 45 ("Of greater concern is the possibility that bankruptcy judges who want to attract large reorganization cases to their district will be under pressure to award attorney fees in excess of existing market rates."); see also Theodore Eisenberg \& Lynn M. LoPucki, Shopping for Judges: An Empirical Analysis of Venue Choice in Large Chapter 11 Reorganizations, 84 CORNELL L. REv. 967 (1999).

144 "Auctions" alter the timing of assessing value, by asking lawyers to fix their fees and their costs in advance of the litigation.

${ }^{145}$ See, e.g., In re Prudential Ins. Co. of Am. Sales Practices Litig., 148 F.3d 283, 342 (3d Cir. 1998).

${ }^{146}$ Note that those lawyers who have agreements for hourly payment from clients get paid for time spent successfully or unsuccessfully, while other forms of payment for time offer compensation only for time spent generating successful outcomes. See, e.g., supra note 25 and accompanying text (discussing the Hensley v. Eckerhart rule that feeshifting statutes require payment from defendants only to plaintiffs' lawyers who prevail and only for prevailing claims).

${ }^{147}$ The idea that the law systematically pays for risk-taking might strike some as odd, but rationales for contingent fees include the concept that, by undertaking the risk of non-compensation for time and expenses, law is urging lawyers to rely on their predictive skills and self-interest to invest with a knowledge of a real risk of loss. Whether risk exists and to what degree, particularly in mass torts, has become a topic of debate. See, e.g., Lester Brickman, Contingent Fees Without Contingency: Hamlet Without the Prince of Denmark, 37 UCLA L. REV. 29, 89-93, 124-26 (1989). For concern that Supreme Court law has undervalued risk in fee-shifting litigation, see Huang, supra note 17, which argues for a conception of litigation as a series of opportunities to go forward or to settle and thereby to use options theory to correct former doctrine that overcompensated, and current doctrine that under-compensates, for the risk of losing. 
against wrongdoers not sufficiently curbed by public law enforcement; ${ }^{148}$ attempting to resolve disputes without adjudicatory processes or before such processes have been completed; ${ }^{149}$ settling cases; withdrawing cases; promoting group-wide resolution of complaints; ${ }^{150}$ legitimating the legal system through enabling adversary processes to work by articulating distinct and conflictual interests; monitoring compliance with legal norms; ${ }^{151}$ lowering transaction costs and protecting court time; avoiding redundancy by group-based representation and other forms of economy; enabling equitable distribution across similarly situated claimants; inducing claimants to join together to centralize litigation; administering distribution mechanisms; competency, expertise, craft and skill that permits analysis of complex law or fact; ${ }^{152}$ being in relationship to ${ }^{153}$ and representing the interests of clients; ${ }^{154}$ spending time providing information and explaining legal requirements to clients; and therefore serving as emissaries from, translators of, and officers of the courts, as well as gatekeepers, sifting meritorious from specious claims.

${ }^{148}$ Compensation is available even when the economic value to clients is less than the value to lawyers. See City of Riverside v. Rivera, 477 U.S. 561 (1986), in which the majority approved a fee award of $\$ 245,456.25$ for pursuit of a civil rights claim resulting in a recovery by the plaintiffs of less than $\$ 35,000$. The majority rejected the concept that attorneys' fees had to be proportionate to recovery in civil rights cases, which (it believed) vindicated "important civil and constitutional rights" and should not, therefore, be valued solely in terms of the monetary recovery. Id. at 574. The dissenters disagreed, arguing that results were critical to the "reasonableness" of any fee. See $i d$. at 588 (Rehnquist, J., dissenting). However, fee shifts are not required if the economic returns are only "nominal." See Farrar v. Hobby, 506 U.S. 103, 115 (1992).

${ }^{149}$ A parallel, on the criminal side, is giving defendants reductions in sentencing in exchange for admissions of guilt and the willingness to forego trial.

${ }^{150}$ See, e.g., Lewis v. Teleprompter Corp., 88 F.R.D. 11, 14 (S.D.N.Y. 1980) (discussing benefits of consolidation of securities fraud actions).

${ }^{151}$ Fee payments may be "staged" or made on an interim basis. See In re Prudential Ins. Co. of Am. Sales Practices Litig., 148 F.3d 283, 334 n.110 (3d Cir. 1998) (upholding a bifurcated staging of fee award as innovative with a caveat that incentives might be better aligned if fee payments depended on remediation).

${ }^{152}$ See Johnson v. Georgia Highway Express, Inc., 488 F.2d 714, 717-18 (5th Cir. 1974), overruled on other grounds by Blanchard v. Bergeron, 489 U.S. 87 (1989).

${ }^{153}$ The relationship to clients is another of the Johnson factors, described in that case as requiring inquiry into the "nature and length of the professional relationship with the client." Johnson, $488 \mathrm{~F} .2 \mathrm{~d}$ at 719. But this factor is relatively rarely invoked. See, e.g., Ruiz v. Estelle, 553 F. Supp. 567, 594 (S.D. Tex. 1982) ("The meaning of this criterion and its effect on the calculation of a 'reasonable' fee has always been unclear."). One possibility is that, because of an ongoing relationship, a lawyer may be willing to discount current fees based on an expectation of future income. See, e.g., Younger v. Glamorgan Pipe \& Foundry Co., 418 F. Supp. 743, 795 (W.D. Va. 1976), vacated on other grounds, 561 F.2d 563 (4th Cir. 1977).

${ }^{154}$ Cf. Amchem Prods. v. Windsor, 521 U.S. 591, 601-02 (1997); note 163 infra. 
That list is long because I have abstracted the range of services that judges have recognized in their many fee award decisions. In fact, however, the bulk of the action is much narrower. In statutory fee shifting from loser to winner, time and rate (the "lodestar") create the central calculation. ${ }^{155}$ In common fund reallocations, a percentage of the "value" of the fund (percentage of the fund, or "POF") has become the primary focus. ${ }^{156}$ But neither of these abbreviated metrics, ${ }^{157}$ nor the longer catalogue, suffices any longer.

\section{B. Paying for Process}

My colleagues Dennis Curtis, Deborah Hensler, and I have argued that extant economic measures of lawyering utility were insufficient in the context of mass torts. ${ }^{158}$ As discussed in Individuals Within the Ag-

${ }^{155}$ Multipliers, at least for risk, have been precluded by City of Burlington v. Dague, 505 U.S. 557 (1992). For criticism, see Huang, supra note 17, at 1952-67.

${ }^{156}$ Several circuits have endorsed the percentage of the fund method as the means of paying common benefit lawyers; a few leave it to the discretion of the district judge to use that method as contrasted with the lodestar approach. Some judges describe themselves as using a "hybrid" in which they calculate fees under both methods and "check" the amounts that would be received against each other.

Case law percentages awarded in common fund cases range widely, and also vary with whether one set of lawyers are being paid or whether PSC members are being paid atop their own contractual fees. Numbers like one-third or one-quarter are often cited. See, e.g., Camden I Condominium Ass'n, Inc. v. Dunkle, 946 F.2d 768, 775 (11th Cir. 1991) (using $25 \%$ as a "bench mark"); Pozzi v. Smith, 952 F. Supp. 218, 225-26 (E.D. Pa. 1997) (summarizing fee awards and expenses ranging from $19 \%$ to $45 \%$ ). Valuation of the fund is the subject of some litigation in which non-monetary benefits-such as research programs-are included as a part of remedial packages for the plaintiff class. See, e.g., Bowling v. Pfizer, Inc., 922 F. Supp. 1261, 1266-69, 1273-74, 1280-81 (S.D. Ohio) (discussing competing valuations of a settlement fund), affd, 102 F.3d 777 (6th Gir. 1996).

Objectors to the focus on the value of a fund cite the large size of many funds and the view that the risk of litigation is small in some of those instances. See, e.g., Higginbotham, supra note 132, at 2204; Grady, supra note 16, at 132.

A distinct question is how, based on value, to set the fee. See Hay, supra note 4, at 1439-46 (arguing for an optimal fee to be set by the court and derived from a series of calculations that attempt to induce pursuit of claimants' recovery through classwide settlements).

${ }^{157}$ Each has its critics. The lodestar method is labor-intensive for judges. In addition, at least some judges worry that, to "second-guess the judgment of counsel" about time spent, they are also engaged in "highly subjective" work. In re Copley Pharm., Inc., I F. Supp. 2d 1407, 1411 (D. Wyo. 1998) (providing an award), 50 F. Supp. 2d 1141 (D. Wyo. 1999) (overruling objections and affirming the earlier award). The percentage method while less time-consuming has been called a "court-directed game of roulette." Dawson, Lawyers and Involuntary Clients, supra note 57, at 929.

${ }^{158}$ See Resnik, Curtis \& Hensler, Individuals Within the Aggregate, supra note 2, at 32659; Curtis \& Resnik, Contingency Fees, supra note 2, at 426-27. 
gregate, the United States legal system values process. ${ }^{159}$ Lawyers for groups advance group interests, sometimes even to the detriment of individual interests. ${ }^{160}$ When lawyers working for individual clients discharge their obligations properly, they play key roles in enabling clients to participate in and to understand the justice system. Such lawyering is often invisible to judges, who are focused on the lawyers responsible for the group as a whole. Thus, when awarding fees, judges tend to undervalue lawyers who actually serve individual clients. We urged courts to pay for process and for the delivery of legal services to litigants, to value lawyers being in relationship to their clients, and to structure aggregate litigation to maximize the role of individually-retained plaintiffs' attorneys. ${ }^{161}$

As I discuss above, the Supreme Court is now also urging a different deployment of attorneys in mass tort aggregates and, specifically, in class actions. In the two cases decided recently, the Supreme Court added to the list of lawyering tasks that judges should value. In the 1997 decision of Amchem v. Windsor Products, Inc., the Court held that "structural assurance of fair and adequate representation for the diverse groups and individuals affected" was a predicate to approval of class action settlements in which groups of claimants with varying injuries receive different amounts of compensation. ${ }^{162}$ To achieve that end, Amchem insisted on "separate representation to eliminate conflicting interests of counsel. ${ }^{\text {n63 }}$ In the 1999 decision of Ortiz v. Fibreboard Corp., the Court specified another requirement, that if and when limited funds were proposed to be distributed, an "independent valuation" - separate from that provided by the settling opponentswas necessary.

Note that, while Ortiz involved a non-opt-out class predicated on

${ }^{159}$ See Resnik, Curtis \& Hensler, Individuals Within the Aggregate, supra note 2, at 35572.

${ }^{160}$ For example, attorneys for the class owe a duty to the class and can support settlements over objections from named plaintiffs. See, e.g., County of Suffolk v. Long Island Lighting Co., 710 F. Supp. 1428, 1434 (E.D.N.Y. 1989) (discussing the possibility of divergence between class counsel's duty and the opinions of a named plaintiff), affd in part and rev'd in part on other grounds, 907 F.2d 1295, 1325 (2d Cir. 1990); Parker v. Anderson, 667 F.2d 1204, 1210-11 (5th Cir. Unit A), cert. denied, 459 U.S. 828 (1982) (approving a consent decree in a class action over the objections of the named party and class representative).

${ }^{161}$ See Resnik, Curtis \& Hensler, Individuals Within the Aggregate, supra note 2, at 381401.

${ }_{162} 521$ U.S. 591, 627 (1997).

${ }^{163}$ Ortiz v. Fibreboard Corp., 119 S. C.. 2295, 2319 (1999) (describingAmchem).

${ }^{164} I d$ at 2318. 
the finding of a limited fund, the concerns that prompted a call for independent evaluations are not necessarily limited to mandatory classes. Given the Court's observation that an "enormous fee" can "relax" the "zeal for the client," all capped settlement funds (whether crafted as mandatory class actions or as opt-out classes) as well as open-ended funds may well deserve (if not require) independent evaluation, perhaps obtained through the competing subclass structure contemplated in Amchem.

Further, one cannot easily cabin these judicial obligations only to class actions. While Amchem and Ortiz focused on interpretations of the federal class action rule, the concept of "adequate representation" has constitutional underpinnings, as the Court acknowledged in the Matsushita litigation ${ }^{166}$ and has repeatedly discussed in a range of representative litigations. ${ }^{167}$ Judges involved in aggregate dispositions outside the context of class actions should similarly be concerned about the propriety of lawyers consenting on behalf of absentees to disparate distributions of funds across a group of claimants. ${ }^{168}$ Indeed, a century ago, the equitable common fund doctrine saw judges as specially responsible for insuring fair allocations of funds. Whether by MDL or class action and whether in federal or state court, judges have long-standing fiduciary obligations to absentees to ensure the integrity, fairness, and legitimacy of settlements in aggregate litigation. ${ }^{169}$

${ }^{165}$ Id. at 2317 n.30.

${ }^{166}$ See Matsushita Elec. Indus. Co. v. Epstein, 516 U.S. 367,379 n.50 (1996); Monaghan, supra note 128, at 1153 (arguing against courts' power to bind nonresident absentees); cf. Robert G. Bone, Rethinking the "Day in Court" Ideal and Nonparty Preclusion, 67 N.Y.U. L. REv. 193, 199 (1992) (arguing for expansion of the law of nonparty preclusion). The requirement of adequacy is explicated in Epstein $v$. MCA, Inc, $179 \mathrm{~F} .3 \mathrm{~d}$ 641 (9th Cir. 1999), revising, 126 F.3d 1235 (9th Gir. 1997), cert. denied sub. nom. Epstein v. Matsushita Elec. Indus. Co., 120 S. Ct. 497 (1999).

The intertwining of Rule 23 and due process is also familiar from the text of Eisen, although many argue that Eisen's constitutional overtones were unnecessary and illadvised (as well as that its reading of Rule 23 was erroneous). See Fiss, Political Theory of Class Action, supra note 75, at 29; Kenneth Dam, Class Action Notice: Who Needs It? 1974 SUP. CT. REV. 97.

${ }^{167}$ See, e.g., Hansberry v. Lee, 311 U.S. 32, 42-43, 45 (1940); Mullane v. Central Hanover Bank \& Trust Co., 339 U.S. 306, 314 (1950); Phillips Petroleum Co. v.Shutts, 472 U.S. 797, 812 (1985); Martin v. Wilks, 490 U.S. 755 (1989).

${ }^{168}$ Henry Monaghan, supra note 128 , at 1202, also argues that opt-out provisions should not preclude challenge by absent class members in "a forum of their own choosing."

${ }^{169}$ Whether the law of malpractice has any role to play is not clear. A segment of malpractice law now involves claims against lawyers for counseling settlement. See, e.g., Wood v. McGrath, North, Mullin \& Kratz, P.C., 589 N.W.2d 103, 104 (Neb. 1999); Ziegelheim v. Apollo, 607 A.2d 1298, 1301 (N.J. 1992). See generally Steve France, Giv- 
Both of the new Supreme Court decisions require significant departures from the regime of settlements familiar in the "old" civil justice system, with its single-file individual cases. Of course, individual settlements-like aggregate settlements-can have problematic elements. An individual agreement could be the result of bad or insufficiently zealous lawyering, influenced unduly by assurances of fee payments. Further, individual outcomes could also affect competing claimants, eventually impairing absentees' abilities to vindicate rights. But, under current law, judges need make no inquiries when dismissing cases or entering consent judgments. ${ }^{170}$ The unregulated attorneyclient unit is a contractually-bound unit. Agent-principal relations are presumed sufficient, in that the lawyer is imagined to be monitored by the client, and the charter for representation is assumed to be adequately controlled by that client. Consent by the participants to agreements therefore avoids the need for adjudicatory processes.

These are the premises of the civil justice system the Supreme Court in Amchem and Ortiz refused to transpose to the mass tort context. In the aggregate case, the lawyers for the group have no relationship with the great majority of individuals on whose behalf they propose binding closure. A court has endowed the lawyers with such authority. Moreover, because mass tort classes are rarely composed of fungible and functionally identical members, the lawyers for the group are inevitably evaluating (and potentially favoring) some claimants over others. ${ }^{171}$ Agency-principal theories no longer justify ceding all control to a few lawyers. Moreover, even when clear that the "real" representative is not the named plaintiff but a group of lawyers, consent by those lawyers no longer suffices as a proxy for legitimacy.

Rather than rule out such settlements, ${ }^{172}$ the Supreme Court has concluded that judges have to create other proxies for legitimacy

ing Up the Fight: Maryland Joins About a Dozen States Holding Lawyers Liable for Bad Settlements Recommendations, A.B.A. J., Feb. 1999, at 28 (discussing the various standards for imposition of liability).

${ }^{170}$ The caveats are facial illegality or a lack of jurisdiction. See Resnik, Judging Consent, supra note 126, at 59-60.

${ }_{171}$ See, for example, the criticism of the agreement in Amchem, 521 U.S. at 626, in which current clients of certain lawyers were to receive compensation different from future claimants, making only more vivid inter-group disparities that exist in many cases.

${ }^{172}$ Precluding such settlements would mean that class actions, unlike other forms of litigation, were not offered that means of disposition. See Judith Resnik, Litigating and Settling Class Actions: The Prerequisites of Entry and Exit, 30 U.C. DAVS L. REv. 835 (1997). 
through the procedural structures described above. ${ }^{173}$ Interventionist judging and regulated advocacy displace the tradition of laissez-faire lawyering. Further, the civil justice system premise of unaided access also succumbs. In the effort to obtain legitimate outcomes, judges will need to enable access for some claimants, whether achieved through subclasses, objectors, or independent evaluators and whether paid by internalizing the costs to a given litigation or from the public fisc.

Why? Although Amchem and Ortiz also do not focus on attorneys' fees, the Court instructed judges not to rely only upon the lawyers before them. Judges must seek out other participants in order to discharge judicial obligations to test (if not ensure) the adequacy of representation. Although judges may be able to take on some of the work themselves $^{174}$ or find volunteers, they will also need to spend litigation resources. Judges will have to change the law on attorneys' fees either by compensating lawyers who work to make the process (and not only the outcome) better or by relying on state-paid personnel to do so.

\section{Playing It Out}

Let me translate some of these claims into the context of mass tort practice by sketching the kinds of interactions to which the new rules apply. Consider the Supreme Court's requirement that, when mass tort settlements are sought, subclasses receive separate representation to ensure structural legitimacy. How separate do lawyers providing "separate" representation have to be to be adequate representatives?

Start either before a complaint has been filed or soon thereafter, during the early phases of a litigation. When distinctions among claimants are plain at the time of certification, may their various rep-

${ }^{173}$ Cf. Mark C. Weber, A Consent-Based Approach to Class Action Settlement: Improving Amchem Products, Inc. v. Windsor, 59 Orno ST. L.J. 1155, 1160 (1998) (proposing that, in lieu of such judicial efforts, individual consent be obtained from each class member to provide "choice" to each). Such suggestions for "opt-in classes" require that litigants affirm their relationship to the aggregate.

${ }^{174}$ Such engagement moves judges closer towards other countries' roles for judges. See John H. Langbein, The German Advantage in Civil Procedure, 52 U. CHI. L. REV. 823, 825 (1985).

${ }^{173}$ That concern was reflected in the Justices' questioning during the oral argument in Amchem, which raised "hypothetically" what would be different, were there to be "four lawyers, one for the people who brought suit before, one for the people who have the disease already, one for the people who have the thickening, and one for the people who have nothing." Transcript of Oral Argument, Amchem v. Windsor Prods., Inc., 521 U.S. 591 (1997) (No. 96-270), available in 1997 WL 83675, at 56. 
resentatives serve together on a "steering committee" to coordinate the litigation? Presumably, lawyers would find it necessary to collaborate during some phases of litigation, such as during discovery or when formulating legal theories of liability. Whether officially part of the same committee or technically distinct, lawyers will continue to work together. ${ }^{176}$

Separate representation (in the Amchem/Ortiz sense) must thus refer to an effort to ensure that, when conflicting interests emerge, advocates shift alignments. While it is possible that distributions of claimants could be known from the time a class action is first conceptualized and that lawyers could map themselves onto the array of interests, the distinctive interests of claimants will not always be apparent from the outset. In some instances, competition among claimants will emerge during discovery and/or during settlement negotiations, when payments of varying kinds are proposed for groups of claimants. Should judges require reformation of subclasses (tentatively configured, with refinements expected) during the course of negotiations? How might lawyers, already "in" the litigation, shift roles to work on behalf of specific categories of claimants? Are new lawyers to be introduced? From where? Coming from "outside" or drawn from the pool of lawyers with individual clients but not on the lead teams?

Assume one has the "easy" case in which subclasses are evident from the inception. If several lawyers, technically representing distinct subgroups, propose a settlement package-under which, for example, low-end claimants receive from $\$ 30$ to $\$ 60$ and high-end claimants receive $\$ 1.5$ million $^{177}$ - how is a jurist to assess the way in which the values for the different subclasses were negotiated and compromised? Does the fact that subclasses were represented by different lawyers suffice? Or should the mandate of separate representation be translated into the requirement that subclass lawyers present either independent segments of settlements or competing compre-

${ }^{176}$ Cooperation and coordination are needed. "So long as we retain any semblance of our adversary system, no more than a few lawyers can effectively plan and control a litigation." Cooper, supra note 88 , at 926.

${ }^{17}$ This example comes from newspaper descriptions of the Fen/Phen settlement. See David J. Morrow, Fen-Phen Maker To Pay Billions in Settlement of Diet-Injury Cases, N.Y. TIMES, Oct. 8, 1999, at Al; see also Nationwide Class Action Settlement Agreement with American Home Products Corp. at 29-35, In re Diet Drugs (Phentermine/Fenfluramine/Dexfenfluramine) Prods. Liab. Litig., MDL No. 1203, Civ. Act. No. 99-20593 (E.D. Pa. filed Nov. 18, 1999) [hereinafter, Nationwide Fen/Phen Settlement]; Diet Drugs Claims Administration Web Site (visited Feb. 20, 2000) <http://www. settlementdietdrugs.com > (discussing the Nationwide Fen/Phen Settlement). 
hensive packages to judges?

Thus far, I have spoken about measuring the degree to which representation is separate by reference to facts or arguments in records attesting to or contesting the validity of proposed settlements. Other ways to assess the existence of "separate" and "independent" action are familiar in law. One such instance is the decision about whether two corporate actors are independent or one corporation is a subsidiary of another. Piercing the corporate veil often relies on facts developed by inspection of financing and organizational structure, to learn whether institutions that are technically distinct are either receiving funds from the same source or have decision-making authority so intertwined that we need to treat them as a single unit. Separate representation could similarly be understood to mean separate sources of payment, that for lawyers to be "independent" requires that they have independent sources of compensation, rather than all being paid from the same pot. ${ }^{178}$

\section{Revising Fee Law, Refocusing Civil Justice}

The questions outlined above about absentees, separate representation, independent evaluation, and lawyering fidelity require reconsideration of several aspects of judge-made law relating to fees, costs, and subsidies. Current rules will need to shift to reflect the changing premises of the civil justice system.

\section{Regulating Attorney-Client Relationships}

Judicial regulation of contractual fee agreements in tort litigation $^{179}$ has already begun to increase. Judicial "oversight" of those contracts has become a feature of federal mass tort law. ${ }^{180}$ The rulings

${ }^{178}$ See, e.g., Ortiz v. Fibreboard Corp., 119 S. Ct. 2295, 2318 (1999) (discussing the concern that incentives to reach settlement are too great when lawyers' fees come from that settlement).

${ }^{179}$ See generally Ted Schneyer, Legal-Process Constraints on the Regulation of Lawyers' Contingent Fees, 47 DEPAUL L. REV. 371 (1998) (discussing state rules).

${ }^{180}$ See, e.g., In re A.H. Robins Co., 182 B.R. 128, 140 (Bankr. E.D. Va. 1995) (asserting authority to minimize transaction costs under the bankruptcy plan and under the bankruptcy code as well as relying on courts' inherent powers over fees; concluding that attorneys representing claimants would be overcompensated were they to receive the full amounts of their contingency fees on the subsequent distributions of funds on a pro rata basis and limiting such compensation to no more than $10 \%$ of the pro rata payments to claimants), aff'd, Bergstrom v. Dalkon Shield Claimants (In re A.H. Robins), 86 F.3d 364, 371, 373, 378 (4th Gir. 1996) (describing the 10,984 attorneys who received notices of the proposed fee limitation, the 29 attorneys who appeared to con- 
in Amchem and Ortiz support that trend, which is to say that judges are likely to alter contractual terms by requiring that claimants in aggregates make payments to common benefit lawyers by deducting some moneys from fees promised by contract to individual lawyers directly retained by specific clients. ${ }^{181}$

I should note the conceptual possibility of a different tack. The fact of aggregation could be seen as justifying increasing attorneys' fees and expenses on the grounds that aggregation itself creates benefits properly charged against its users. ${ }^{182}$ According to some jurists, aggregation brings plaintiffs "better" lawyers. ${ }^{183}$ Moreover, aggregation costs money, and both defendants and plaintiffs who benefit directly could be required to fund such costs (atop whatever payments they make as fees or expenses to individually retained lawyers).

test the limitation, and affirming the district court's jurisdiction, the process it afforded the attorneys, and its ruling), cert. denied sub nom. Bergstrom v. Dalkon Shield Claimants Trust, 519 U.S. 993 (1996); see also In re A.H. Robins Co. (Norris), 205 B.R. 771, 772-72 (Bankr. E.D. Va. 1997) (rejecting an individual attorney's request to permit full fees because she had waived and reduced some contingency fees for applicants, because of her time-intensive assistance of individuals, and because of the debt claimed to have been incurred in the course of her practice); In re A.H. Robins Co. Inc. (Medical Claims Consultants), 205 B.R. 767, 773-74 (Bankr. E.D. Va. 1997) (rejecting an application to exempt a consultant group that assisted Dalkon Shield claimants from the fee limitation and warning attorneys that any withholding of funds from clients would be deemed a violation of the court order); In re A.H. Robins Co. (Cashman \& Partners), 211 B.R. 536, 539 (Bankr. E.D. Va. 1997) (rejecting an Australian lawyer's request for fee reinstatement based on his having taken a 25 percent, rather than a 33 percent fee); In re A.H. Robins Co. (Linker), 211 B.R. 533, 535-36 (Bankr. E.D. Va. 1997) (rejecting a petition for fee reinstatement based on a request that the court distinguish between those attorneys who invested extensive time and effort for clients before Robins declared bankruptcy and those attorneys who were retained after the bankruptcy filing).

A settlement that was proposed in the breast implant litigation also included fee caps and superintendence. See Resnik, Curtis \& Hensler, Individuals Within the Aggregate, supra note 2, at 339 n.147. The proposed Fen/Phen settlement requires that defendants reserve nine percent of all payments to create a fund from which "common benefit" lawyers are paid. See Nationwide Fen/Phen Settlement, supra note 177, §VIII(E).

${ }^{181}$ Hopefully, judges will have the patience and information to sort among individual lawyers and distinguish those lawyers who worked intensely in advance of aggregation from those lawyers who joined at later stages, when risk and work requirements have been reduced substantially.

${ }^{182}$ See Rosenberg, Class Actions for Mass Torts, supra note 97, at 593-95 (arguing that the pooling of resources enables better outcomes than the disaggregative individualistic tort process).

${ }^{183}$ See, e.g., In re Copely Pharm. Inc. Litig., 1 F. Supp. 2d 1407, 1418 (D. Wyo. 1998). The judge concluded that aggregation conferred the benefit of better lawyering at lower rates on litigants and reduced individual fee payments by two-thirds in three of the funds, and by one-third in the fourth fund, giving the surpluses to class counsel. 
Suggesting that aggregation be used to increase litigants' transaction costs is not fanciful, despite claims that aggregation provides economies of scale (presumptively to courts, although such assumptions often do factor in how aggregation increases incentives for filings of certain kinds of claims). Current law includes a willingness to charge users of aggregation some of its direct costs. ${ }^{184}$ But contempo-

${ }^{184}$ For example, a trial judge "assessed" defendants in one mass tort $\$ 41,500$ per defendant to pay for costs of a joint document depository and the costs of a liaison for defendants. See In re Two Appeals Arising Out of the San Juan Dupont Plaza Hotel Fire Litig., 994 F.2d 956, 960 (1st Cir. 1993). Also detailed were planned but abandoned assessments for litigants to subsidize construction of a special courtroom. See id. at 96061. The First Circuit held that district courts have the "authority [implied under federal discovery rules] to reallocate court-imposed case-management expenses if, in the exercise of its considered judgment, it determines that equity and the interests of justice so require." Id. at 965 . The district court's order requiring those payments was subsequently affirmed. See In re Three Additional Appeals Arising Out of the San Juan Dupont Plaza Hotel Fire Litig., 93 F.3d 1, 6 (1st Cir. 1996).

While information about defendants' costs is often not readily available from published reports, information about the costs of aggregation for plaintiffs is made public through requests for reimbursement made by common benefit lawyers. Many of those lawyers, working together on steering committees, create ad hoc law firms to litigate a particular case. Sometimes the costs of such firms are minimal; the participants may use their home offices as a base, travel relatively infrequently, and rely heavily on telecommunication. But in other instances, the ad hoc firm rents an office, hires staff, buys office equipment, prints stationery, hires experts, holds meetings, conducts depositions, and the like.

Note that, because such committees are creatures of lawsuits, they do not directly have clients. Thus, unless retainer agreements are modified in advance of, or upon the creation of, such committees, no client has agreed by contract to pay the costs of aggregation, and hence questions emerge about who pays and how much. The practice has developed that, with court approval in pre-trial management orders, each plaintiff's attorney is assessed specific amounts (hundreds or thousands of dollars per client) to fund a litigation. At the conclusion of the lawsuit, an accounting occurs during which common benefit lawyers apply to courts to be reimbursed by plaintiffs for the "costs" of aggregation. Such requests are not always successful. See, e.g., In re San Juan Dupont Plaza Hotel Fire Litig., 111 F.3d 220, 237, 239 (1st Cir. 1996) (requiring that a PSC return more than $\$ 1$ million charged to plaintiffs as costs-in payment to a lawyer, charged as an expert, and in payment for items such as $\$ .25$ per page photocopying); see also In re Showa Denko K.K. L-Tryptophan Prods. Liab. Litig.-II, 953 F.2d 162,166 (4th Gir. 1992) (overturning in part an administrative order in which every plaintiff was taxed $\$ 1000$ plus " 0.5 [percent] of the value of settlement or verdict" entered into on the basis that all derived benefits from a steering committee's discovery).

What should be calculated as "costs" fairly charged to plaintiffs, when they are charged inappropriately for "more" than would have been charged in individual litigation, is made complex by differing practices associated with contingent fee and hourly wage lawyers. For example, contingent-fee percentages generally have been assumed to capture all staff costs including paralegal or associate work, while hourly billing attorneys charges such time to clients. Further, all attorneys are expected to specify, in advance, methods of billing and what items are to be charged as costs. See ABA Comm. on Ethics and Professional Responsibility, Formal Op. 93-379 (1993) [hereinafter 
rary hostility to lawyers' fees (viewed by many as excessive) makes imposition of additional attorneys' fees upon aggregate users unlikely. Instead, trial judges have relied on individual fee contracts to create the pool from which all attorney fees are paid. And, as noted, judges have begun to reserve some of the money ${ }^{185}$ (formerly conceived to "belong" to individual attorneys) to pay common benefit lawyers. ${ }^{186}$ The prior civil justice approach, that adult clients and their attorney can contract to become a unit presumptively undisturbed by judicial oversight, is displaced in favor of a regulatory model.

Amchem and Ortiz also displace an imagined attorney-client relationship between aggregate lawyer and aggregate client. Keenly aware that lawyers are often the largest stakeholders in aggregate litigation (receiving fees far in excess of any individual claimant's recovery), judges now have to monitor such lawyers. ${ }^{187}$ To reduce the difficulties,

Formal Op. 93-379]; ABA Comm. on Ethics and Professional Responsibility, Formal Op. 94-389 (1994). Contingency fee attorneys are supposed to explain whether any such expenses will be paid directly by the client before or after the percentage fee is calculated. And, according to the American Bar Association, attorneys are not supposed to profit from the provision of certain services, such as the cost of making a photocopy, but may be able to recoup "overhead expenses directly associated with the provision of the service." Formal Op. 93-379, supra, at 215; see also Spicer v. Chicago Bd. Options Exch. Inc., 844 F. Supp. 1226, 1260 (N.D. Ill. 1993) (concluding that firms should not run their "photocopy operations as profit centers"). Hence, the mode of fee payment (hourly billing versus contingent billing) may turn some categories of expenses from "overhead" into charges paid directly by clients.

A few district courts have responded by requiring attorneys to specify a proposed percentage that accounts for both forms of charges. See, e.g., In re Oracle Sec. Litig., 131 F.R.D. 688, 689-90 (N.D. Cal.), order modified by, 132 F.R.D. 538, 539 (N.D. Cal. 1990) (requiring competitive bidding); In re Wells Fargo Sec. Litig., 156 F.R.D. 223, 228-29 (N.D. Cal. 1994) (requesting bids from proposed lead counsel and requiring information on proposed costs and fees). Other techniques include imposing a cap for both fees and costs together or calculating fee percentages on the net, rather than the gross, settlement fund value. See, e.g., LaChance v. Harrington, 965 F. Supp. 630, $647-48$ n.15 (E.D. Pa. 1997) (relying on the net rather than the gross amount for fee calculation, but declining to include the costs of the administration of the fund as part of the net calculation).

${ }^{185}$ See, e.g., Nationwide Fen/Phen Settlement, supra note 177, § VIII(E) (recording agreements within a Memorandum of Understanding Concerning Settlement of Diet Drug Litigation, Oct. 6, 1999, and providing for setting aside nine percent from the percentage amount to which the attorney is entitled "under any valid written contingent fee agreement with the Class Member" to be used for paying "common benefit" lawyers).

${ }^{185}$ When to make such announcements and how to allocate those fees have been contested. See, e.g., In re Nineteen Appeals Arising Out of the San Juan Dupont Plaza Hotel Fire Litig., 982 F.2d 603 (1st Cir. 1992); In re Thirteen Appeals Arising Out of the San Juan Dupont Plaza Hotel Fire Litig., 56 F.3d 295 (1st Cir. 1995); supra note 180 (discussing fee limits imposed in the A.H. Robins litigation).

${ }^{187}$ Under current ethical rules, lawyers who represent more than one client are 
courts could require common benefit lawyers to provide fee and cost information through electronic databases, accessible by telecommunications to and from many locales. Without such reporting requirements, difficult and costly work is entailed in digesting accountants' reports of time and moneys spent by lead lawyers and their staffs. ${ }^{188}$ But even with such information (not routinely available now) individual litigants-named plaintiffs or other members of an aggregatewould be hard pressed to monitor lawyers' investments. Similarly insufficient is reliance on self-review by steering committee members $^{189}$ or oversight from lawyers who do not sit on steering committees but represent individuals within a collective. Participating attorneys, while connected to individual clients, also have incentives to forge connections to repeat-player aggregate lawyers who have the power to make referrals and include lawyers in the next litigation. Further, not only are individually retained lawyers unlikely to be aggressive monitors, such monitoring is both time and resource consumptive. Hence the turn to judges, who themselves will be eager to reduce their own monitoring costs. To do so, judges might consider revisiting the idea of screening the merits of aggregate litigation in its early phases, ${ }^{190}$ consider employing assistants, and/or turn to rules

prohibited from making aggregate settlements of such claims without each client's individual consent, entered into after full disclosure. Class actions are conceived as not implicating the rule because of court findings that clients' interests are homogeneous. Compare MODEL RULES OF PROFEsSional CONDUCT Rule 1.8(g) (1995), with Charles Silver \& Lynn A. Baker, Mass Lawsuits and the Aggregate Settlement Rule, 32 WAKE FOREST L. REv. 733, 736 (1997) (arguing that such rules may unduly burden the bargaining plaintiffs' attorneys in "mass lawsuits" and that lawyers and clients should be permitted to agree to alternative requirements).

${ }_{185}$ Required are labor intensive evaluative analyses of bills and expense reports that include understanding the relationships among bills claimed by different attorneys. Assume, for instance, that lawyer A on a PSC claims time and expenses for travel to a particular place to work with lawyers B and C. One would then have to cross-check reports, to learn if all lawyers report the same amount of time spent. Yet another question is whether all three were needed to do the work. To put such burdens of reconstruction and evaluation on lawyers representing individual clients in a mass tort litigation is to misperceive both those lawyers' capacities and incentives. But cf. In re San Juan Dupont Plaza Hotel Fire Litig., 111 F.3d 220, 238 (1st Cir. 1997) (criticizing individually retained plaintiff' attorneys for failure to monitor costs more closely during earlier phases of the litigation and rejecting many of their complaints about PSC overspending).

${ }^{189}$ Many pre-trial management orders require common benefit plaintiff lawyers to file monthly reports of fees and costs, prepared by retained accountants, often appointed by courts and paid as "costs" by the claimants.

${ }^{190}$ See, e.g., Eisen v. Carlisle \& Jacquelin, 417 U.S. 156, 168, $177-78$ (1974) (discussing the hearing, held by the district judge in Eisen to evaluate plaintiffs' likelihood of success on the merits, and its ruling, subsequently reversed, shifting costs of notice to defendants). 
about lawyers' fees to create incentives for lawyers to represent loyally the diverse segments of an aggregate. ${ }^{191}$ Measures used to value attorneys' work need to be revisited.

\section{Reassessing Measures of Value, Regulating Advocacy, and Requiring Disclosures}

Recall that lawyers are frequently paid a percentage of the value of a fund that they have worked to accumulate for a group of plaintiffs. ${ }^{192}$ Consider again the proposed settlement drawn from newspaper accounts of the pending diet drug litigation, the "Fen/Phen" settlement. A matrix of recoveries is provided, within which one group of claimants would receive somewhere between $\$ 30$ and $\$ 60$, representing the money expended on prescriptions for the drugs, while another group would receive compensation of hundreds of thousands of dollars. ${ }^{193}$ If lawyers for the subclass of low value Fen/Phen users are paid a percentage of the fund obtained by that subclass, those lawyers will be paid little in contrast to the lawyers paid for the subclass eligible for the $\$ 1.5$ million recoveries. Yet the mass tort settlement system must rely on as energetic and zealous lawyering from low-value subclass lawyers as from high-value subclass lawyers in order to validate the entire

${ }^{191}$ Costs will also need to be monitored, and one suggestion here is that the relatively inexpensive (in time and resource) solution of relying on formulas for the recoupment of costs has not been much used. For example, government employees, including judicial officers, abide by cost schedules and have per diem limits. See also Guidelines for Reviewing Applications for Compensation and Reimbursement of Expenses Filed Under 11 U.S.C. $\$ 330,28$ C.F.R. 58 app. A (1999) (specifying the information required).

192 That practice raises problems in mass torts from vantage points other than the concerns about adequate representation. One issue is how to measure the value of a fund, and case law reflects debates about how to monetize benefits, such as medical monitoring programs or research commitments. See Bowling v. Pfizer, Inc., 922 F. Supp. 1261, 1280-81 (S.D. Ohio), affd, 103 F.3d 128 (6th Cir. 1996). A second issue is the difficulty of assessing the value of diverse contributions made by a range of lawyers to a particular outcome. How does one assess relative contributions of some attorneys who excel in negotiation, others who work in court, and yet others who construct legal theories? Further, in aggregations with multiple plaintiffs and defendants, key contributors to plaintiffs' recoveries may come from lawyers other than those who represent the plaintiffs, such as defense attorneys who successfully shift blame away from their clients in a fashion that enables recovery from other defendants.

${ }^{193}$ See supra text accompanying note 177 . I do not know nor am I commenting on the legal merits of that settlement or of the injuries allegedly caused by the drugs. Rather, assume that that amount of recovery is "right," in the sense that these individuals have not and will not manifest physical injury, have no reasonable basis to dread becoming physically ill, and yet were sold a drug for which they should be reimbursed because it should not have been on the market. 
package. And, while given the number of claimants in Fen/Phen, that settlement may produce significant monetary recoveries for lawyers of all subclasses, some aggregates have hundreds (not tens of thousands) of litigants, and therefore low-end claimants may be represented by lawyers who, if paid solely from their subclasses' funds, would receive small amounts of money.

Thus, the percentage of the fund rule as customarily calculated may not provide sufficient incentive for lawyers to represent zealously clients likely to receive relatively small economic benefits from group litigation. Those lawyers not only provide value to their direct clients, they also help the civil justice system dispose equitably of cases through aggregated settlements. Reevaluation of the way to pay either the low-end lawyers or other lawyers may sometimes be needed to obtain equally committed, quality lawyering for all segments of claimants and/or to provide payments for the value of such dispositions to the public.

Several different formulas could develop, each with advantages and problems. My goal here is to flag some of the purposes and difficulties of various routes. Examples include efforts to monetize the public benefit and apportion those dollars among various lawyer groups, permitting ex ante contracts to govern fee distributions, or trying to import economic analyses developed to generate quality "team production" within corporations to provide means of improving the alignment of incentives. ${ }^{194}$ While some commentators assume that linking attorneys' fees through the percentage of the fund method to subclasses is the preferred method, I think that is but one of several options, to be selected depending upon the context. Alternatives also include calculation of costs and attorneys' fees as a percentage of the economic value of the entire litigation, conceived to stem from the work of all attorneys ("low end" and "high end" alike), to be divided

194 See Margaret M. Blair \& Lynn A. Stout, Team Production in Business Organizations: An Introduction, 24 J. CORP. L. 743 (1999). The model of team production rests on three conditions: (1) economic production requires a team of two or more individuals; (2) team members' investment of resources have a "significantly higher value" when used in the team; and (3) the resulting gains are "joint and nonseparable, making it difficult to attribute any particular portion of the gains to any single team member's contribution." Id. at 745. How much this model, elaborated in the context of corporate governance, informs the transitory organizational structures extant in mass tort litigation, is an open question. Because aggregate litigation involves work of many participants and raises parallel problems of fidelity and monitoring, regulatory responses should explore how much to borrow from other arenas aspiring to align incentives in complex relationships among principals and agents. 
among the participating lawyers. ${ }^{195}$ Divisions, reflecting varying investment and risk levels as well as work performed, could help support a market for representation of the diverse segments within group litigation. Yet, judicial efforts to appraise the varying degrees to which different lawyers contributed to the entire settlement would be both labor consumptive and arbitrary (replete with after-the-fact valuation of what turned out to be useful ${ }^{196}$ ) and/or provide a means by which certain lawyers gain "inner circle" status by being deemed specially valued by judges. But if fees are split equally across lawyers, that allocation could result in energetic representation of the cohort as a whole but not necessarily vigilance about particular subclasses' interests. In short, self-consciousness about the effects of such efforts may counsel the development of a range of fee and cost formulas to mitigate the problems caused by any one approach and to respond to the knowledge that participants are repeat players.

For example, an alternative would be for the common benefit doctrine to borrow an aspect of fee-shifting law, that public norm enforcement confers a public good, justifying investments disproportionate to economic returns. ${ }^{197}$ One could pay all lawyers through the lodestar method, perhaps adding "multipliers" for those lawyers who

${ }^{195}$ Charging groups of plaintiffs' lawyers with the pursuit of competing settlement packages is also a theoretical possibility, with the incentive of paying a premium to that group of lawyers coming in with the best proposal (which is to say the proposal the court approves). But the burden on defendants to work with different sets of lawyers and agree to different settlements and the difficulties judges would have weighing the varying tradeoffs made by the competing regimes make that route unlikely in practice.

${ }^{196}$ See, e.g., In re Indigo Sec. Litig., 995 F. Supp. 233, 235 (D. Mass. 1998) (describing conflicting descriptions of whether sets of lawyers harmed or helped claimants, deferring generally to lead counsel to distribute fees, and commenting that the court was "surprised and dismayed to be confronted with this unseemly controversy over attorneys' fees. It is in no position to evaluate the relative merits of the lawyers' chosen litigation strategies ...."). Further, how does one value defense lawyers' contributions or those of judicial officers to settlement?

197 See City of Riverside v. Rivera, 477 U.S. 561 (1986) (discussed supra note 148); see also Quaratino v. Tiffany \& Co., 166 F.3d 422, 425-26 (2d Cir. 1999) (finding erroneous the application of a "billing judgment" approach because it conflicted with the legislative intent and the Supreme Court rule that the value of client's civil rights not be equated with "monetary terms"); Morales v. City of San Rafael, 96 F.3d 359, 363 (9th Cir. 1996) (distinguishing nominal from "de minimis" awards in a case in which a "significant nonmonetary result" for the individual and the community was achieved), amended by, 108 F.3d 981 (9th Gir. 1997); Krumme v. Westpoint Stevens Inc., 79 F. Supp. 2d 297, 303 (S.D.N.Y. 1999) (declining, in a lawsuit contesting rights under an employee benefits plan, to rely on a formula using one-third of the amount in controversy to cap an award of attorneys' fees and discussing how the "reasonableness" of attorneys' fees needs to be assessed by reference to the purposes behind a fee-shifting rule). 
took greater risks by investing in the litigation at its early stages or who provided unusually able lawyering, again with the caveats about the difficulties of ex post review. ${ }^{198}$ Further, one could reserve funds to pay those lawyers who continue to serve clients during the distribution stage.

But if all the lawyers are paid from the same settlement fund and therefore have an economic stake in getting a shared outcome, has separate representation really been undertaken? Won't all the lawyers share an interest in getting everyone "on board" to get paid? As long as all the lawyers draw their fees from a group-wide result, all of the lawyers for plaintiffs will continue to be economic allies. ${ }^{199}$ Of course, when lawyers represent individuals, incentives to get a result exist as well, but the conception is that client control constrains attorney behavior. Aggregate litigation lacks such constraints, and if all the lawyers need the settlement to get paid, no group of lawyers has an incentive to risk the collapse of an agreement, but rather only an incentive to feign such risks as a means of extracting additional payments, as discussed below.

One response is to attempt to disentangle claimants' recovery from lawyers' fees and expenses. Recall that the Third Circuit had a rule that, in statutory fee-shifting cases, fee negotiations were to occur only after the conclusion of remedial negotiations for claimants. ${ }^{200}$ But, in Evans v. Jeff $D$., the Supreme Court held that bargaining under federal fee-shifting statutes could include negotiations about lawyers' fees. ${ }^{201}$ All elements of an agreement could be on the table at once, which meant that defendants could offer outcomes in exchange for reduced obligations to pay lawyers' fees. (Givil rights lawyers some-

${ }^{193}$ Such an approach would require revision of the law of those circuits in which percentage of the fund, as compared to lodestar, is the preferred method of payment when common funds are created. See, e.g., Democratic Cent. Comm. of D.C. v. Washington Metro. Area Transit Comm'n, 3 F.3d 1568, 1573 (D.C. Cir. 1993). But many opinions describe district judges as having some range of discretion. See, e.g., In re General Motors Corp. Pick-Up Truck Fuel Tank Prod. Liab. Litig., 55 F.3d 768, 819-22 (3d Gir. 1995); Johnston v. Cenlar Fed. Sav. Bank, 83 F.3d 241, 246 (8th Cir. 1996); Cook v. Niedert, 142 F.3d 1004, 1010-11 (7th Cir. 1998).

${ }^{199}$ Turning to defendants to provide money does not solve this problem. Payments to lawyers made directly by defendants (for example, as "set asides" from claimants' recoveries) is a possibility that in essence reframes a common fund award into a feeshifting award. But all lawyers for plaintiffs continue to have stakes in achieving a global outcome.

${ }^{200}$ See Prandini v. National Tea Co., 557 F.2d 1015, 1017 (3d Gir. 1977), overnuling noted by Ashley v. Atlantic Richfield Co., 794 F.2d 128, 137-38 (3d Cir. 1986).

201475 U.S. 717, 765 (1986). 
times responded to this holding by obtaining contracts, in advance of litigation, by which clients agreed that their lawyers would not waive fees when bargaining.) Could judges in mass torts insist on the prior Third Circuit regime, in which fee negotiations were required to follow upon conclusion of outcomes on the merits? Judicial oversight of negotiations (through a court-appointed monitor, for example, required to be present during such negotiations ${ }^{202}$ to police compliance) might work to ensure that attorneys' fees and costs not be discussed. When an agreed-upon sum was decided and apportioned among subclasses, judges could order set-asides to form a fund from which lawyers could compete for their fees and costs. (In other words, the boundaries between fee-sharing and fee-shifting blur. ${ }^{203}$ ) Judges could compensate lawyers for time and skill (either by lodestar or percentage) and also pay premiums to lawyers who demonstrated fidelity to a subgroup's interests, thereby enabling civil justice processes to function. ${ }^{204}$

Given these many difficulties with creating structural integrity within the circle of co-venturing lawyers engaged in settlement negotiations, looking to outsiders becomes another means of validating the process. The Supreme Court directive that courts seek outside views on the value of funds and their distribution beyond those proffered by

${ }^{202}$ See, e.g., In re Synthroid Mktg. Litig., 1998 WL 526566, at *3-*4 (N.D. Ill. Aug. 17, 1998) (rejecting a proposed settlement and discussing an ongoing role for a special master, appointed at the parties' request, to participate in settlement negotiations); see also In re Synthroid Mktg. Litig., 188 F.R.D. 287 (N.D. Ill. 1999); 188 F.R.D. 295 (N.D. III. 1999) (both certifying classes-of insurance providers and of consumers, respectively-in litigation against manufacturer of prescription drug alleged to have suppressed evidence of the utility of a generic substitute).

${ }^{203}$ Further, decisions about when to shift fees have market consequences as well, not only in terms of helping to finance segments of the legal community but also in terms of affecting incentives about what forms of legal redress to pursue. The "catalytic theory" (described supra note 25) that permits fee shifting not only when civil rights litigants obtain an enforceable judgment (whether by consent or adjudication) but also when such litigants prevail because a defendant changes its course of action after the filing of a lawsuit rewards settlement of disputes.

${ }^{204}$ Further, lawyer fees might be paid periodically, to ensure that lawyering continues to be provided until all claimants receive benefits. "Staged" or "bifurcated" fees is the current nomenclature. See, e.g., Bowling v. Pfizer, Inc., 927 F. Supp. 1036, 1043 (S.D. Ohio. 1996) (discussing future fee awards related to work yet to be done); see also In re Prudential Ins. Co. of Am. Sales Practices Litig., 148 F.3d 283, 334 n.110 (3d Cir. 1998) ( $[B]$ asing the second portion of the fee on the number of claims actually remediated would better serve the district court's goal of encouraging class counsel's continued participation."); In re Teletronics Pacing Sys., Inc., 186 F.R.D. 459, 485-86 (S.D. Ohio 1999) (discussing "holdback" fees by providing installment payments to attorneys parallel to the ways in which class members received compensation). 
the settling parties requires that a thread of attorney fee law, which sometimes provides payments to objectors, will need to thicken, ${ }^{205}$ which is to say that objectors should presumptively receive compensation. For objectors to function well also requires that their access to information become much better than is often the practice now, in which discovery rights are narrow. ${ }^{206}$ Similarly, rules on standing for appeal would need to become welcoming of dissenters. ${ }^{207}$

${ }^{205}$ As is proposed in the appendix to the REPORT ON MASS TORT LITIGATION, supra note 1, app. F-7, at 7 (proposing a new Rule 23.3(f)(2) (Mass Tort Actions), which would require awards of costs, including fees, incurred to "support a successful objection"). Courts have awarded fees to objectors upon finding that objectors have improved outcomes. See, e.g., Gottlieb v. Barry, 43 F.3d 474, 491 n.16 (10th Cir. 1994); In $r e$ Horizon/CMS Healthcare Corp. Sec. Litig., 3 F. Supp. 2d 1208, 1214 (D.N.M. 1998); Petruzzi's Inc. v. Darling-Delaware Co., 983 F. Supp. 595, 599-600 n.4, 621-23 (M.D. Pa. 1996).

A few courts have also awarded fees on the basis that opposition itself makes for a better understanding of the fairness of a settlement, even when a proposed settlement is affirmed. See, e.g., Feinberg v. Hibernia Corp., 966 F. Supp. 442, 455 (E.D. La. 1997); Maywalt v. Parker \& Parsley Petroleum Co., 864 F. Supp. 1422, 1439 (S.D.N.Y. 1994). Other courts refuse payment on grounds that objections neither "assisted the court nor enhanced the recovery." In re Prudential Ins. Co. of Am. Sales Practices Litig., 148 F.3d at 330 n. 100 (quoting the district court order).

Fees for objections-both to the merits and to the fee awards-may be paid from plaintiffs' common fund and on occasion from money allocated to class counsel. See, e.g., Duhaime v. John Hancock Mut. Life Ins. Co, 2 F. Supp. 2d 175, 176 (D. Mass. 1998), affd, 183 F.3d 1 (1st Gir. 1999); In re Horizon/CMS Healthcare, 3 F. Supp. 2d at 1215; see also Marcel Kahan \& Linda Silberman, The Inadequate Search for "Adequacy" in Class Actions: A Critique of Epstein v. MCA, Inc., 73 N.Y.U. L. REv. 765, 778 (1998) (arguing that the desirability of centralizing litigation makes appropriate payments to outside lawyers in competing cases).

${ }^{206}$ See, e.g., Duhaime v. John Hancock Mut. Life Ins. Co., 183 F.3d 1 (1st Cir. 1999) (upholding a district court's denial of a class member's motion to compel discovery).

${ }^{207}$ Rather than require (as many courts do) that class members "intervene" as a predicate to appeal (thus creating a set of second-class parties, bound by the outcome but without rights to invoke appellate review) courts could conclude that all members of an aggregate have the right to bring appeals. Compare Felzen v. Andreas, 134 F.3d 873, 875-76 (7th Cir. 1998) (noting the role of outsiders as monitoring the "faithfulness or honesty of self-appointed plaintiffs," but holding that "non-party shareholders" in derivative actions filed under FED. R. CN. P. 23.1 who did not intervene as well as "non-parties ... of any kind in a class action" may not appeal; the sole remedy under current Seventh Gircuit doctrine is to persuade "the district judge that the representative is unfit or unfaithful or that subclasses should be created"), aff'd. by an equally divided court sub nom. California Pub. Employees Retirement Sys. v. Felzen, 525 U.S. 315 (1999), with Kaplan v. Rand, 192 F.3d 60, 67-73 (2d Cir. 1999) (disagreeing with Felzen and permitting appeal of fee award by a shareholder objecting to fees paid). See also Crawford v. Equifax Payment Servs., 201 F.3d 877 (7th Cir. 2000) (holding that intervention should be permitted when a class member presented objections to the district court). See generally Susanna M. Kim, Conflicting Ideologies of Group Litigation: Who May Challenge Settlements in Class Action and Derivative Suits?, 66 TENN. L. REV. 81, 111-19 (1998) (criticizing the Seventh Gircuit rule). See also Georgine v. Amchem Prods., No. 
But at both trial and appellate levels, courts will also have to make law sorting appropriate complaints and constructive proposals from over-optimistic dissents ${ }^{208}$ and/or extortion. ${ }^{209}$ Drawing those distinctions is difficult, entailing weighing the benefits of settlement for the aggregate against claims of inadequate dealmaking. Let me offer an example, extrapolating only slightly from contemporary litigation. Take a mass tort involving a medical product or a toxic tort, processed either by class action or an MDL. Assume that a court-appointed cadre of lawyers negotiates a settlement providing for distribution of significant sums of money across a group of claimants whose injuries vary from major traumas (say, valued above $\$ 500,000$ ) to minor injuries (valued at under $\$ 5000$ ). Some of the claimants with high value injuries have lawyers, who know that, had they proceeded through the old civil justice system, some of their clients would receive more. Assume that a few of these lawyers appear at the fairness hearing and dispute the parameters of the settlement. ${ }^{210}$

Unsuccessful, the objectors file a notice of appeal or indicate to the aggregate's lawyers that they intend to do so. The aggregate lawyers in turn offer to pay those clients premiums if they do not pursue their appeals. Responsible lawyers, representing individuals, might

97-1608 (3d Cir. Apr. 28, 1998) (dismissing an appeal filed by objectors to the payment by defendant asbestos manufacturers for the costs of plaintiffs' lead attorneys in Amchem v. Geongine).

${ }^{203}$ See, e.g., Martins v. Smith Barney, Inc., 181 F.R.D. 243, 265 (S.D.N.Y. 1998) ("The court's fiduciary duty to class members entails not only protecting an objecting minority, but also protecting a non-objecting majority from a 'veto' by dissenting members.").

${ }_{209}$ See Richard B. Schmitt, Objecting to Class-Action Pacts Can Be Lucrative for Attomeys, WALL ST. J., Jan. 10, 1997, at B1; see also In re Factors VIII or IX Concentrate Blood Prods. Litig., 159 F.3d 1016, 1020 (7th Cir. 1998) (raising concerns about goals of attorneys seeking to upset a settlement after its distribution was underway).

${ }^{210}$ A real-life variant of this scenario is detailed in briefs filed by Public Citizen, objecting to payments made to dissenters in the Shiley Heart valve litigation. See Brief of Appellants Jeffrey A. Crane, Gene Randall, and Gerard Benedik at 7, Bowling v. Pfizer, Inc., 132 F.3d 1147 (6th Cir. 1998) (No. 96-3568) (on file with the University of Pennsylvania Law Review) [hereinafter Appellants Crane et al.'s Brief/Pfizer]. According to the brief, an objecting lawyer argued in federal court that a proposed settlement was "completely inadequate." Id. at 7 n.3. Subsequently, defendants agreed to pay objecting lawyers "\$3.25 million to dismiss their Sixth Circuit appeal," and class counsel provided "an additional $\$ 750,000$ " in lawyers' fees. Id. at 7. According to the brief, that agreement fell through when a Pennsylvania court declined to approve the fee arrangement. See id. at 8-9 n.5. Thereafter, class counsel, seeking to block payment to that objector in the federal proceeding, argued that the objector had not provided any "benefit to the class." Id. at 7; see also In re Copley Pharmaceutical Inc., 50 F. Supp. $2 \mathrm{~d}$ 1141, 1153 (D. Wyo. 1999) (rejecting claims about a lead counsel "cutting side deals ... and playing favorites" as unverified). 
well counsel their clients to accept the larger recoveries (which they had sought by means of appeal) but which are now offered as a means of avoiding appeals. ${ }^{211}$

One appraisal of these interactions is that lawyers for the objectors have successfully threatened the group's lawyers into paying their clients (and themselves) money, in exchange for an agreement that insulates the settlement from appellate review. But before one too quickly criticizes the group's lawyers for "buying off" an appeal, consider that the group's lawyers could reasonably believe that the settlement represents a just outcome and that the appellate processes-potentially including challenges to the propriety of group litigationraise risks of (at best) a belated distribution to most members of the group.

Of course, lawyers for the high-value claimants may not be the only ones threatening to appeal. Other lawyers-for claimants that seem to have less economically viable claims-might also join such an appeal, thereby holding up the distribution for the bulk of claimants who occupy the middle range. Should the group's lawyers pay appellants at the low end as well? Not only are there thus various forms of "side settlements," litigants too are the recipients of some of the funds, and lawyers may also have agreements with other lawyers that result in economic enrichment in exchange for withdrawing objections.

These interactions are occurring in mass tort litigation now, but mostly off-stage, unrecorded by case law and unevaluated by judges. More than that, some courts have ruled that such side settlements do not affect a group-wide agreement and therefore are not the business of courts. ${ }^{212}$ I counsel the opposite approach: to use individual settlements to shed light on the fairness of aggregate settlements. Judges should mandate disclosure of side agreements as a means of enhancing their ability to monitor aggregates' lawyers. These side-settlements

${ }^{211}$ Of course, briefs in reported cases and occasional decisions provide less attractive examples, including those in which it appears that lawyers are offered premiums to forgo pursuing their disagreements with group wide settlements. See Brief for Appellant Howard M. Metzenbaum at 4-7, Duhaime v. John Hancock Mut. Life Ins. Co., 183 F.3d 1 (1st Cir. 1999) (No. 98-2139) (on file with the University of Pennsylvania Law Review); Appellant Crane et al.'s Brief/Pfizer, supra note 210, at 7-8; see also Schmitt, supra note 209 , at Bl (describing a payment by lead lawyers increasing objectors' lawyers fees from the $\$ 400,000$ that a mediator had recommended to $\$ 1$ million, after which an appeal was dropped, and quoting a judge as preferring "finality rather than to hold the [settlement] up any further").

${ }_{212}$ See Duhaime, 183 F.3d at 6 (relying in part on a lack of a "tradition of court intervention"). 
are a form of an "independent" evaluation, or at least a valuation different than that provided by the aggregates' lawyers. Upon learning that some claimants are being paid sums different from those offered through group processes, judges will have to evaluate whether those cases are idiosyncratic, whether they are appropriate buy-outs of interested but dissenting parties, or whether such payments reflect back badly on the values paid to the subgroup similarly situated to such litigants. Judges will then have to decide whether similarly situated claimants within the group should have been paid at the sidesettlement rate, and, if so, whether to do so by reopening the terms of the settlement ${ }^{213}$ And to the extent that the side-settlement rate offers a discount by avoiding payments to common benefit lawyers-such as the nine percent reserve in Fen/Phen-judges should prevent such free riding bargainers from garnishing the benefits but avoiding the costs of aggregation. Alternatively, if the side-settlement buys out something valuable (like a credible threat of going to trial), then such premiums can be paid to those who are willing to risk leaving the safety of the settlement aggregate to forage on their own.

This point, about what lies outside the aggregate settlement but is spawned in its wake, raises a question about the relevance of the distinction drawn by the Ortiz Court between mandatory and opt-out classes. ${ }^{214}$ The Court's focus on the conceptual and doctrinal distinction between opt-out and mandatory classes may have less salience in practice. The theoretical existence of exit rights may provide comfort when determining the legality of binding litigants, but for litigants to exercise their exit rights requires knowledge, resources, and control over attorneys. ${ }^{215}$

${ }^{219}$ When such information is obtained after judgment has been entered, Federal Rule of Civil Procedure 60 could provide an opportunity to revisit that judgment, just as it currently is used to review consent decrees in large scale structural litigation. See Rufo v. Inmates of Suffolk County Jail, 502 U.S. 367 (1992); Agostini v. Felton, 521 U.S. 203, 237-40 (1997).

${ }^{214}$ How to appraise the desirability of mandatory classes is one issue. Given that the civil justice system aspires through aggregate tort litigation to treat like claimants alike, mandatory classes provide a means of accomplishing that goal. See Shapiro, supra note 2, at 925-26.

${ }^{215}$ See Monaghan, supra note 128, at $1168-86$ (criticizing the reliance on opt-out provisions to legitimate representation as adequate to substantiate court's "power to bind" and objecting to making the availability of due process challenges "alone turn on the existence of baroquely written notices that are designed to discourage action and that require the recipient to take an affirmative action to protect his or her rights"). For further discussion of notice and opting out, see Brian Wolfman \& Alan B. Morrison, Representing the Unrepresented in Class Actions Seeking Monetary Relief, 71 N.Y.U. L. REv. 439 (1996); and George Ruthenglen, Better Late Than Never. Notice and Opt Out at 
Once aware of the need to worry about lawyers' roles as representatives of aggregate clients, why should that worry evaporate when lawyers are counseling clients about exit rights? Take, for example, an agreement among lawyers on a mass tort committee that, "Should the court certify the class as frame..., all Committee members will strongly recommend that all plaintiffs in existing litigation and all other clients remain as members of the certified class., ${ }^{216}$ Given such agreements that bind lawyers to counsel joint venturing, judges cannot rely on lawyers to advise clients to exit. If judges want to link exit rights to the legitimacy of court action, judges will have to insist on expansion of such opportunities and supervise lawyers' communications of the availability of this alternative. Further, as discussed above, exit undermines the goals of equitable treatment across litigants and sometimes permits lawyers and litigants to gain the benefits of aggregation without paying its costs. In short, opt-out rights are a poor means of validating group-based processing.

Judicial reluctance to learn too much about the economic relationships among lawyers should also be reappraised. As the Ninth Circuit recently explained, " $[t]$ here is very little case law concerning the allocation of attorneys' fees among co-counsel. ${ }^{\text {s217 }}$ Under the Amchem/Ortiz mandates, however, the disclosure of clients' agreements and of lawyers' fee-sharing agreements becomes a means of learning whether different subclasses or interests were separately represented, or whether groups of lawyers, technically distinct, have intermingled

the Settlement Stage of Class Actions, 71 N.Y.U. L. REv. 258 (1996).

${ }^{216}$ HIV Litigation Steering Committee Policy Guidelines, para. 4 (on file with the University of Pennsylvania Law Review). Also included was a provision specifying that if a "global settlement" was reached, with or without a class action, members agreed to make "every effort" to "profile cases in terms of their relative values under the tort system" and not to "compromise the relative rights of individual categories of victims." Id. at para. 10.

${ }_{217}$ In re FPI/Agretech Sec. Litig., 105 F.3d 469, 473 (9th Cir. 1997) (upholding the rejection of such agreements and concluding that district courts may reject fee allocation agreements upon finding "that the agreement rewards an attorney in disproportion to the benefits that attorney conferred upon the class-even if the allocation in fact has no impact on the class"). Judge Alex Kozinski's dissent expressed disapproval of such "judicial meddling" in contractual agreements to allocate fees absent effects on class recoveries. Id. at 477; see also In re Prudential Ins. Co. of Am. Sales Practices Litig., 148 F.3d 283, 338-40 (3d Cir. 1998) (approving a district court declining to allocate fees in favor of lead counsel doing so); In re Copley Pharm. Inc., $50 \mathrm{~F}$. Supp. 2d 1141, 1148-49 (D. Wyo. 1999) (discussing the difficulties of courts providing allocations and aspiring to having lawyers decide "the allocation themselves"; when conflict arose, the court described itself as combining a deference to lead counsel as being "like the Court as the presiding jurist" and "in a unique position to weigh the contributions to the litigation" with a review of objections; then overruling the objections). 
their streams of income. While formally independent, many mass tort lawyers have complex interdependent economic relationships, not only through direct payments but also through subsequent channeling of work. ${ }^{218}$

Law has long used economic affiliation as a proxy for loyalty. Lawyers are not permitted to represent clients with competing interests unless those clients are told of and consent to that representation. ${ }^{219}$ Moreover, when lawyers receive "block" settlements on behalf of a cohort of clients, each client is supposed to be told of the others' recovery and consent to the distribution. ${ }^{220}$ Further, lawyers are supposed to be paid in relationship to the work that they did for specific clients. Therefore, in addition to assigning different lawyers to subclasses to fulfill the Amchem and Ortiz mandates, judges will also need to inquire into the financing of the litigation and the organizational structure of the lawyering units to learn whether subclass lawyers (whose connection to the subclasses that they officially represent derives from judges) have reasons to be loyal to a subgroup of clients and the degree to which their own fiscal and professional well-being turns on being a team player within a lawyer cohort. Agreements by which lawyers pool recoveries can undermine whatever fee allocation system judges provide. Therefore, judges need to know "the bottom line," that is, not only what money officially is paid to specific lawyers, but how much, in fact, those lawyers earn from their roles in mass tort aggregates that judges sanction. ${ }^{221}$

This suggestion could be understood as a broadened application of the Second Circuit's rule that all fee sharing contracts in class actions be provided, when formulated, to courts. ${ }^{222}$ But neither case law

${ }^{218}$ Referral fees, legal in some states, are an example. See STEPHEN DANIELS \& JOANNE MARTIN, "THAT'S 95\% OF THE GAME, JUST GETIING THE CASE": MARKET, NORMS AND HOW TEXAS PLAINIIFFs' LAWYERS GET GIIENTS 13-16 (American Bar Foundation Working Paper \#97222, 1997); see also Charles W. Wolfram, Mass TortsMessy Ethics, 80 CORNEII L. REV. 1228, 1232 (1995) (describing attorneys who "parlay the small favors and back scratching of a series of class-action cases into a position of influence and sizable fees in a future class action of one's own").

219 See MOdEL RULES OF PROFESSTONAL CONDUCT Rule 1.7 (1997).

220 MODEl Rules OF Professional. Conduct Rule 1.8(g) (1997). Criticism of this approach can be found in Charles Silver \& Lynn Baker, I Cut, You Choose: The Role of Plaintiff's Counsel in Allocating Settlement Proceeds, 84 VA. L. REv. 1465, 1535-39 (1998).

${ }_{221}$ If fee awards and settlement approvals are decided disjunctively, then disclosure should still be required and settlement approvals revisited, when necessary, upon learning that the economic arrangements among lawyers impaired the structural integrity of such settlements. $C f$. Bowling v. Pfizer, 102 F.3d 777, 781 n.3 (6th Cir. 1996).

${ }^{222}$ See In re "Agent Orange" Prod. Liab. Litig., 818 F.2d 210, 225 (2d Cir.), cert. de nied, 484 U.S. 926 (1987); see also S.D.N.Y. \& E.D.N.Y. LOCAIR. 23.1 (requiring publi- 
nor anecdote provides much evidence that attorneys' fee agreements are routinely revealed, and few participants have incentives to enforce that rule. ${ }^{223}$ Further, to the extent that the rule has been interpreted to require only disclosure to courts, ${ }^{224}$ judges become totally reliant on the honesty of the disclosures and are without means of gaining information independently to evaluate accuracy or completeness. ${ }^{225}$

In addition to using attorneys' agreements as a vehicle for implementing the Amchem/Ortiz rules, judges have another reason to insist on revelation of lawyers' financial agreements. By appointing common benefit lawyers (as well as appointing or approving administrators of document depositories, auditors and accountants, and staff of claims facilities) and by allocating, cutting, or adjusting fees and costs, judges play a significant role in the large-scale aggregate tort litigation market. That market, in turn, is populated by "repeat player" ${ }^{\text {"26 }}$ lawyers, judges, and staff. Given the high degree of visibility of mass torts and the allegations of ethical breaches, ${ }^{227}$ judges should be particularly

cation of fee-sharing agreements in advance of hearings in class and shareholder actions); MODEL RULES OF PROFESSTONAL CONDUCT Rule 1.5(e)(2) (1997) (requiring clients to be advised of and not object to divisions of fees between lawyers not members of the same firm). Professor Nancy Moore has a higher level of confidence than I do that ethical rules can be a means of responding to the problems documented. See Nancy J. Moore, Ethics Matter Too, 148 U. PA. L. REV.2209, 2215-19 (2000).

${ }_{225}$ Brian Wolfman, on behalf of Public Citizen Litigation Group, has proposed that FED. R. Grv. P. 23(e) be amended to require "disclosure and approval of sidesettlements." See Letter from Brian Wolfman to the Hon. Anthony J. Scirica, Chair of the Standing Committee on Rules of Practice and Procedure, and the Hon. Paul V. Niemeyer, Chair of the Advisory Committee on Civil Rules, (Nov. 23, 1999) (on file with the University of Pennsylvania Law Review).

${ }^{224}$ See Bowling v. Pfizer, 102 F.3d at 780.

${ }^{225}$ Contemporary practice supports secrecy, justified as protecting plaintiff class members by preventing defendants from knowing, ex ante, how much money plaintiffs' lawyers are prepared to spend in pursuit of a claim. See Lawyer Fined $\$ 1,000$ in Bid Disclosure, N.Y. TIMES, May 20, 1999, at C2 (discussing a $\$ 1000$ sanction imposed by a judge against a lawyer whose firm had not become lead counsel in a derivative action; upon court approval of a $\$ 340$ million settlement, he questioned fees paid to counsel and disclosed the bids by those firms that had initially sought to be lead counsel and with whom he had competed). The "auction" for counsel and the requirement of "sealed bids" is described in In re Cendant Conp. Litigation, 182 F.R.D. 144, 150 (D.N.J. 1998). See also John C. Coffee, Jr., Securities Class Actions, NAT'L L.J., Sept. 14, 1998, at B6 (discussing how auctions can exacerbate attorney incentives to settle quickly, and arguing that caps are inappropriate for that reason as well as commenting on the difficulty judges have in appraising bids).

${ }_{2 \times 6}$ Marc Galanter deployed this phrase in his insightful essay, Why the "Haves" Come Out Ahead: Speculations on the Limits of Legal Change, 9 LAW \& Soc'Y REV. 95,97 (1974).

297 See Lester Brickman, Address, The New Business of Government.Sponsored Litigation: State Attorneys General and Big-City Lawsuits, (June 22, 1999) (presented at a panel, The Politics and Economics of Government Sponsored Litigation, sponsored by the Federalist Society, The Manhattan Institute, and The U.S. Chamber Institute for Legal 
careful that their own images not be tarnished, either by criticisms that judges have not paid attention to how money has been distributed under their aegis or that through such distributions, judges have created patronage systems. Helpful, in this regard, would be an empirical analysis of the composition of lawyers' committees and staff personnel across mass torts, that, after evaluating variables (expertise, client base, financial capacity etc.), would illuminate the degree of redundancy and its plausible explanations.

Note that the approaches outlined thus far entail displacement of yet another precept of attorney fee law, that fee petitions not become "a second major litigation." ${ }^{228}$ The settlement, side-settlement, fee agreements, fee-sharing, and costs package now becomes a form of litigation, to which discovery rights must attach ${ }^{229}$ and for which ample notice would have to be distributed. ${ }^{230}$ Practices, case law, and local rules would have to change. ${ }^{231}$

Revisiting yet another doctrine within contemporary attorney fee law flows from this discussion. As the federal law of attorneys' fees develops as a means of enabling federal processes such as class actions and MDLs to draw legitimately to a close, federal attorney fee law becomes a part of federal equity, res judicata, and federal procedural law, some of it based on rules and common law doctrine and other

Reform) (on file with the University of Pennsylvania Law Review) (arguing that attorneys general hire lawyers who have or will contribute to political campaigns).

${ }^{223}$ Hensley v. Eckerhart, 461 U.S. 424, 437 (1983).

229 See REPORT ON MASS TORT IITIGATION, supra note 1, app. F-7, at 5 (proposing a new FED. R. CTV. P. 23.3, section ( $f$ (2) of which provides for discovery of settlement negotiations and fees in mass tort actions); $i d$ app. F-8 at 2 (proposing a rule governing attorneys' fees for class actions that authorizes courts to permit discovery when class members object to fees). But $f_{f}$. In re Prudential Ins. Co. of Am. Sales Practices Litig., 148 F.3d 283, 325, 341 (3d Cir. 1998) (upholding limits on discovery into settlement fairness).

230 See, e.g., REPORT ON MASS TORT LIIIGATION, supra note 1, app. F-8, at 2 (proposing a "Class Action Attorney Fee Rule" which would require that all parties be informed of pending applications and permit-at the court's discretion and without specification of the amount or kind- "a party or class member" to obtain "discovery in aid of proposed objections ${ }^{n}$ ). Studies of contemporary practices in class actions suggest problems with notice requirements. See Thomas E. Willging, Laural L. Hooper \& Robert J. Niemac, An Empirical Analysis of Rule 23 to Address the Rulemaking Challenges, 71 N.Y.U. L. REv. 74, 127-28 (1996) (describing a study of class actions in four districts and finding "no notice at all in six certified (b) (3) actions and finding delayed notices in sixteen certified (b) (3) cases that eventually settled" and suggesting "that the lack of a precise timetable or guideline" in the rules may have allowed parties "to postpone or avoid notice").

${ }^{231}$ See, e.g., FED. R. Grv. P. 54(d) (2)(D) (authorizing local rulemakers to provide "special procedures by which issues related to [attorneys'] fees may be resolved without extensive evidentiary hearings"). 
aspects reflecting constitutional concerns about how to effectuate the guarantees of due process of law. The current rule is that attorneys' fees are "substantive" for Erie purposes, ${ }^{232}$ but at least when fees are an artifact of federal aggregation and settlement processes, such fee and cost awards could be conceived as "procedural" and hence appropriately governed by federal, rather than state, law.

\section{Judicial and Congressional Subsidies}

This recital of the obligations on judges and of the necessity of delving deeper into the relationships among attorneys and between attorneys and clients makes attractive reconsideration of the role of public subsidies. Rather than internalize structural protections to litigation and burden participants and judges with creating and monitoring such protections, public resources could be used to provide salaries for lawyers or experts upon whom judges could rely. Such public employees, paid without regard to the outcomes of settlements, could provide "independent" evaluations and represent groups within aggregates. Further, unlike successful "objectors" who, if able to convince a court not to enter a settlement, may recoup nothing, employees of the state have no such disincentive to press fundamental attacks on proposed settlements.

The argument for using tax dollars comes from the view that mass tort settlements enhance inter-litigant equity by enabling a wider group of injured individuals to recoup for injuries inflicted than would the single-file system and by helping courts to avoid repetitive or conflicting decision making and thereby reducing the queue for judicial services. Given that structural legitimacy in mass tort settle-

${ }^{232}$ Alyeska Pipeline Serv. Co. v. Wilderness Soc'y, 421 U.S. 240, 259 n.31 (1975) (discussing the practice before Erie of applying state statutory attorney fee law in diversity cases and concluding that "nothing after Erie" altered the rule and moreover, that "a judicially created rule" would also have to be applied). As the Court later explained, that principle does not preclude federal courts from shifting fees when imposing sanctions for misbehavior. See Chambers v. NASCO, Inc. 501 U.S. 32, $51-55$ (1991). The current law is also a bit muddier than the Alyeska citation suggests; for example, the Fifth Circuit has ruled that, while the entitlement to a fee is a matter of state law, an "unanswered question [is] whether state or federal law controls the calculation of fees." Robinson v. State Farm Fire \& Cas. Co., 13 F.3d 160, 164 (5th Cir. 1994). Trial courts within that circuit have sometimes considered both state and federal calculation rules and, in at least one instance, compared outcomes under both and split the difference. See Keeton v. Wal-Mart Stores, Inc., 21 F. Supp. 2d 653, 656-62 (E.D. Tex. 1998). But see Mangold v. California Pub. Util. Comm'n, 67 F.3d 1470, 1479 (9th Cir. 1995) (concluding that state law determines both the entitlement to fees and the method of calculation). 
ments confers benefits on the public, the public might well be charged with helping to facilitate that form of disposition.

Public funding offers a means by which judges could mitigate the reliance on lawyers already in the case by taking on some of the work (including that of independent evaluation) themselves, by appointing "technical advisors" or "experts, ${ }^{233}$ by relying on special masters, ${ }^{234}$ or by using court personnel such as magistrate judges. Substantial funding would require congressional action but modest public subsidies may be available by the use of court personnel already obliged to perform "additional duties" consistent with their statutory mandates. ${ }^{235}$

Turning to the state to subsidize forms of group litigation is not novel. Within current bankruptcy practice, the Office of United States Trustee provides an example of employees-in this instance of the Justice Department-who work to ensure the legitimacy of configurations of aggregates within bankruptcy. ${ }^{236}$ Another precedent comes from the late 1970s, when Daniel Meador directed the Office for Improvements in the Administration of Justice within the Justice

${ }^{239}$ See, e.g., Hall v. Baxter Health Care Corp., 947 F. Supp. 1387, 1393 n.9 (D. Or. 1996) (discussing the appointment of a panel of experts pursuant to FED. R. Evm. 104 as well as the inability to obtain federal funding for them, resulting in the payment by the parties of $\$ 76,000$ in fees); In re Silicone Gel Breast Implant Prod. Liab. Litig. (MDL 926), No. CV92-P-10000-S (N.D. Ala. May 30, 1996 (Order No. 31)), at 4 (describing efforts to "seek at least partial funding" of expert costs from the Administrative Office of the U.S. Courts and requiring that if such costs exceed whatever funds become available, the plaintiffs' Common Benefit Fund and the national defendants would each pay one-half); see also Howard M. Erichson, Mass Tort Litigation and Inquisitorial Justice, 87 GEO. L.J. 1983, 1989-91 (1999) (discussing the order in In re Silicone Gel Breast Implant Prod. Liab. Litig., supra). The Judicial Conference funded the panel in part, and the Federal Judicial Center is conducting research on the use of such panels.

${ }^{254}$ See FED. R. CTV. P. 53. For thoughtful analysis by a special master in school desegregation cases of his efforts to formulate remedial plans, see Curtis J. Berger, Away from the Court House and into the Field: The Odyssey of a Special Master, 78 COLUM. L. REv. 707 (1978).

${ }_{235}$ See FED. R. GN. P. 54(d) (2)(D) (allowing courts to refer attorney fee issues to magistrate judges "as if it were a dispositive pretrial matter"), 28 U.S.C. $\$ 636$ (b) (3) (authorizing magistrate judges to undertake such "additional duties as are not inconsistent with the Constitution and laws of the United States"); see also REPORT ON MASS TORT LITIGATION, supra note 1, app. F-7 at 7 (adverting to a role for magistrate judges in settlements).

${ }^{225}$ See 28 U.S.C. $\$ \S 581-589$ (1994) (establishing the office of United States trustee); see also 11 U.S.C. \$1102(a) (1994) (setting forth roles for United States trustees in organizing creditor committees). The Attorney General sets salaries for trustees, who are paid by a special fund from the Treasury. See 28 U.S.C. \$\$ 587-589a (1994). Guidelines for review of applications for compensation in bankruptcy can be found at 28 C.F.R. § 58 app. A (1999). 
Department; he proposed legislation to create class action litigation conducted by the Department of Justice on behalf of small consumer claimants. $^{237}$ A third example is contemporary; attorneys general across the United States are bringing lawsuits on behalf of states or cities, seeking recoupment for expenditures due to injuries. ${ }^{238}$

Yet another means of shifting to a publicly financed system, or a mixed system (with special taxes, for example, on a particular industry) is of course to create agencies to adjudicate some of the cases now falling under the rubric of mass torts. ${ }^{239}$ Proposals for administrative agencies to handle asbestos have been proffered for several years, ${ }^{240}$ with one pending now that some believe has a stronger likelihood of enactment than in the past. ${ }^{241}$ But administrative solutions are not panaceas. While specific mass torts may be sufficient in number to occasion the political engagement and agreement necessary to create agencies in their honor, many will not be. Further, moving the processes to the administrative arena will require Congress to answer some of the questions now determined by courts, including whether to permit any form of aggregate processing in that venue and whether to

${ }^{237}$ See S. 3475, 95th Cong. (1978) ("Public and Class Compensating Actions"). The proposal was the subject of hearings but was not enacted; it is detailed in Patricia L. Wells, Note, Reforming Federal Class Action Procedure: An Analysis of the Justice Department Proposal, 16 HARV. J. Legis. 543 (1979). See also ABA Section on Litig., Report and Recommendations of the Special Committee on Class Action Improvements, 110 F.R.D. 195 (1986); Arthur R. Miller, Of Frankenstein Monsters and Shining Knights: Myth, Reality, and the "Class Action Problem," 92 HARV. L. REV. 664, 684 (1979); see also Jill E. Fisch, Class Action Reform: Qui Tam, and the Role of the Plaintiff, LAW \& CONTEMP. PROB., Autumn 1997, at 167, 198-202 (discussing such "hybrid" litigation, by which public-private partnerships for norm enforcement could be formed).

${ }^{233}$ See Wendy E. Wagner, Rough Justice and the Attorney General Litigation, 33 GA. L. REV. 935 (1999). Because of contemporary federalism doctrine, such volunteer efforts do not raise the problems that a congressional mandate to state law enforcement officers might encounter. See Printz v. United States, 521 U.S. 898 (1997).

${ }^{259}$ See, e.g., Richard A. Nagareda, In the Aftermath of the Mass Tont Class Action, 85 GEO. L.J. 295, 359-63 (1996) (arguing that a link between litigation and agencies might be desirable, that Congress should experiment by giving agencies authority to obtain primary jurisdiction and stay individual claims while an agency investigates causation and injury).

${ }^{240}$ See Lester Brickman, The Asbestos Claims Management Act of 1991: A Propasal to the United States Congress, 13 CARDOZO L. REV. 1891 (1992); Deborah R. Hensler, Fashioning a National Resolution of Asbestos Personal Injury Litigation: A Reply to Professor Brickman; 13 CARDOZO L. REv. 1967 (1992) [hereinafter Hensler, Reply to Professor Brickman].

${ }^{241}$ See Fairness in Asbestos Compensation Act of 1999, S. 758, 106th Cong., $\$ 508$ (1999); Fairness in Asbestos Compensation Act of 1999, H.R. 1288, $\$ 508$ (1999) (proposing a fee cap for lawyers of $25 \%$ of damages received by claimants as a result of the proceeding); see also Labaton, supra note 117 (describing lobbying efforts on behalf of the bill). 
regulate attorneys' fees. In instances when Congress has located adjudicative remedies inside administrative settings, Congress has often capped and regulated attorney fees, which in turn has meant that higher profile and higher paid lawyers migrate elsewhere. That result might appropriately reflect the lower demands on lawyers for that form of representation or may be a means by which to deter such lawyers from becoming combatants with the segments of industry affected by a given administrative rubric.

The discussion of such public subsidies requires a return to a pervasive concern about overuse, a concern that exists no matter what form subsidies take, whether in agencies or courts and whether by direct public funding or by means of altering private incentives. Easing access provides not only the benefit of ready filing; it also may make entry so easy that not only "low value" but also "no value" claims can be filed. Predicting the numbers of people in need of government subsidies (be they for federal or state benefits of an array of kinds) has proved difficult in all settings. ${ }^{242}$ Getting the optimal level of filings and avoiding both bad lawyers and bad claims are similarly problematic enterprises. Subsidies for litigation are therefore clumsy, both over- and under-inclusive, ${ }^{249}$ as are most forms of government intervention, however attractive they may also be.

\section{TRANSPARENT INDEPENDENCE}

I have no doubt that the suggestions for an amalgam of common law and constitutional development coupled with congressional enactments that I have made in response to contemporary aspirations for civil justice seem ambitious. So does that to which the civil justice system now aspires-to respond to claimants as members of groups, to do so sometimes by settlement, and to do so in a fashion that legitimates the outcome so that it can be called a judgment of a court. Be-

212 See Hensler, Reply to Professor Brickman, supra note 240, at 1987-88.

2ts Over-and under-claiming within the current system has been documented; one study described both injured persons who had not sought redress and others, not injured, obtaining recoveries. See PAUL C. WEIIER, HOWARD H. HIITT, JOSPEF P. NEWHOUSE, WIIIIAM G. JOHNSON, TROYEN A. BRENNAN \& LUCIAN L. LEAPE, A MEASURE OF MAIPRACTICE: MEDICAL INJURY MALPRACTICE LITIGATION AND PATIENT COMPENSATION (1993). Another study reviewed the utility of facilitating filings in the context of the Dalkon Shield litigation. At the time of the bankruptcy filing, some 15,000 to 30,000 claims had been filed against A.H. Robins. Media notification programs prompted the filing of some 300,000 additional claimants, of which more than 200,000 were deemed valid. See Herbert M. Kritzer, Public Notification Campaigns in Mass Litigation: The Dalkon Shield Case, 13 JUST. SYs. J. 220 (1988-89). 
ing ambitious is not (at least in this political culture) a criticism. Further, as Ben Kaplan put it thirty years ago:

\begin{abstract}
There are some who are repelled by these massive, complex, unconventional lawsuits because they call for so much judicial initiative and management. We hear talk that it all belongs not to the courts but to administrative agencies. But by hypothesis we are dealing with cases that are not handled by existing agencies, and I do not myself see any subversion of judicial process here but rather a fine opportunity for its accommodation to new challenges of the times.
\end{abstract}

Today's "new challenges" make insufficient the civil justice system's past efforts to accommodate quietly to economic inequities. The modestly explained (or undertheorized) due process/equal protection cases mandating litigant subsidies do not begin to respond to the access and free-rider issues that aggregate litigation illuminates. Frank engagement with civil justice as a government service provided as a means of forwarding public purposes is required. Economists worry about these problems in terms of collective action, agency costs, and free riders. Lawyers have to worry also about the integrity and intelligibility of governmental institutions. Given that both courts and legislatures want to offer (and to promote) court-based settlements of aggregates, they must generate sufficient evidence of the adequacy of such group-wide settlements to attach legal meaning to them, to have judges warrant them sufficient to bind.

To do so, judges and/or legislatures must require and sometimes fund the production of information to enable investigation into the quality of representation. Whatever one's views of how well "backroom deals" work within Congress, they do not work in courts, which are institutions in democracies whose processes are required to be more publicly accessible and transparent than those of legislatures. The civil justice system is a process in which the constitutional norms of constrained and accountable government are played out on a daily basis through encumbering judicial roles by insisting on dispassionate neutrality and public accountability. Thus, amidst the many revisions and evolutions that a civil justice system can tolerate and indeed celebrate, a few premises should not be altered. Judges must remain disinterested actors, uniquely powerful and therefore uniquely constrained as contrasted to other political appointees and bureaucrats of the government. Moreover, their peculiar posture must be accessible and visible to the public.

${ }^{244}$ Benjamin Kaplan, A Prefatory Note, 10 B.C. INDUST. \& COM. L. REV. 497, 500 (1969) [hereinafter Kaplan, A Prefatory Note]. 
Transparent independence is the last shorthand I will offer in this essay. Judges need to have it, which is why I counsel visible processes, filled with mandates for disclosure by lawyers and law pronouncement by judges. Of course, such requirements impede the ease of bargaining and, in practice, will make some deals undoable. That brings me to incentives for judges, and about how to cushion their understandable interest in closure, their worries about dockets, and their concerns for litigants, so as to be able to rely upon judges to apply requirements that will, in some cases, be inefficient but will serve other social goals. Whether judges can and will embrace such tasks and whether law and social practices will help to sustain the commitment to the unique role of judges remain to be seen. ${ }^{245}$ These are yet other "new challenges of the times." 246

245 See Resnik, Transforming the Meaning of Article III, supra note 11, at 992-1020, 1024-31.

${ }^{245}$ Kaplan, A Prefatory Note, supra note 244, at 500. 
$* \quad * \quad * \quad * \quad * \quad *$

HeinOnline -- 148 U. Pa. L. Rev. 2196 1999-2000 